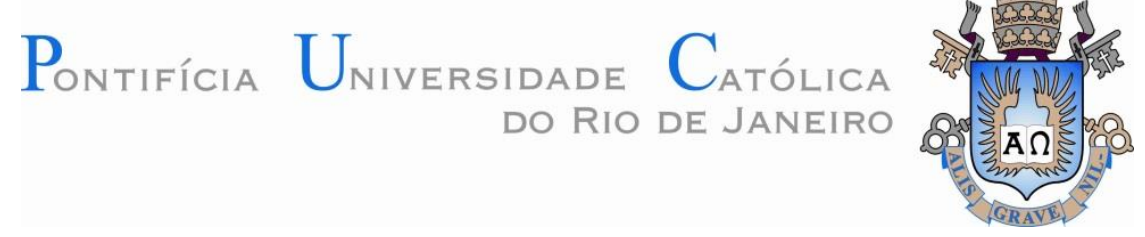

Cláudio Rocha Bastos

\title{
Embalagens compostáveis: uma estratégia para a redução de impacto ambiental
}

\section{Dissertação de Mestrado}

Dissertação apresentada como requisito parcial para obtenção do título de Mestre pelo Programa de Pós-Graduação em Metrologia (Área de concentração: Metrologia para Qualidade e Inovação) da PUC-Rio.

Orientadores: Prof. Maurício Nogueira Frota Co-orientador: Dr. Fabrício Casarejos Lopes Luiz Co-orientador: PhD. Carlos Rufin 
Cláudio Rocha Bastos

\title{
Embalagens compostáveis: uma estratégia para a redução de impacto ambiental
}

\begin{abstract}
Dissertação apresentada como requisito parcial para obtenção do título de Mestre pelo Programa de PósGraduação em Metrologia (Área de concentração: Metrologia para Qualidade e Inovação) da PUC-Rio. Aprovada pela Comissão Examinadora abaixo assinada.
\end{abstract}

Prof. Maurício Nogueira Frota

Orientador

Programa de pós-graduação em Metrologia - PUC-Rio

Prof. Fabrício Casarejos Lopes Luiz

Co-orientador

Universidade de Lisboa

Prof. Carlos Rufin

Co-orientador

Suffolk University

Prof. Rodrigo Flora Calili

Programa de pós-graduação em Metrologia - PUC-Rio

Prof. Luís Felipe Guanaes Rego Núcleo Interdisciplinar de Meio Ambiente - PUC-Rio

Prof. José Eugênio Leal Coordenador Setorial do Centro Técnico Científico - PUC-Rio Rio de Janeiro, 15 de setembro de 2015 
Todos os direitos reservados. É proibida a reprodução total ou parcial do trabalho sem autorização da universidade, do autor e do orientador.

\section{Cláudio Rocha Bastos}

Formado em Engenharia Mecânica pela Universidade Católica de Petrópolis, RJ em 1972. Presidente da Babcock \& Wilcox para o Brasil e América do Sul (1981-1988). Fundador \& CEO da CBPAK Tecnologia S/A (2002-2015).

Ficha Catalográfica

Bastos, Cláudio Rocha
Embalagens compostáveis: uma estratégia para a
redução de impacto ambiental / Cláudio Rocha Bastos;
orientador: Maurício Nogueira Frota; co-orientador:
Fabrício Casarejos Lopes Luiz, Carlos Rufin. - 2015.
93 f. : il.; $30 \mathrm{~cm}$
Dissertação (mestrado)-Pontifícia Universidade
Católica do Rio de Janeiro, Centro Técnico Científico,
Programa de Pós-Graduação em Metrologia, 2015.
Inclui bibliografia
1. Metrologia - Teses. 2. Metrologia. 3. Metrificação. 4.
Monetização. 5. Resíduos sólidos. 6. Custo ambiental. I.
Frota, Maurício Nogueira. II. Luiz, Fabrício Casarejos
Lopes. IV. Rufin, Carlos. V. Pontifícia Universidade
Católica do Rio de Janeiro. Centro Técnico Científico.
Programa de Pós-Graduação em Metrologia. VI. Título.


A todos aqueles a quem tive a oportunidade de conhecer em minha carreira profissional. Àqueles a quem dedico o meu amor e recebo muito mais em troca, que são as mulheres de minha vida Yedda, Heloísa, Camila, Olívia, Gabriela, Laia, Maria Isabel, Maria Luiza e Betina, e aos meus heróis Lucas (in memoriam), Guilherme, Rodolfo e Lucas Júnior. Aos membros da equipe CBPAK, que não medem esforços para vencer as batalhas que o pioneirismo impõe. Que o Senhor a todos abençoe com amor e alegria por terem contribuído para este trabalho. 


\section{Agradecimentos}

Ao meu amado irmão Lucas Bastos Júnior, grande incentivador da realização deste trabalho.

Ao meu orientador o professor Maurício Nogueira Frota pela parceria, todos os ensinamentos e a orientação durante o decorrer desta empreitada.

Aos meus coorientadores os professores Fabrício Casarejos Lopes Luiz e Carlos Rufin pela parceria, todos os ensinamentos e orientação durante o decorrer desta empreitada.

Ao amigo Eugênio "Zeca" Neiva por compartilhar comigo do conhecimento de algo pioneiro.

À PUC-Rio, pelos auxílios concedidos, sem os quais esta dissertação de mestrado não poderia ter sido concluída.

À equipe técnica e administrativa do Programa, Márcia Ribeiro, Paula Guimarães e Jaime Ticona pelo apoio.

À equipe da empresa Green Domus, pela assessoria e no trabalho realizado.

À CBPAK Tecnologia S/A, empresa fabricante dos copos de mandioca, que nos forneceu todo o material e apoio técnico para a realização da pesquisa. 


\section{Resumo}

Bastos, Cláudio Rocha; Frota, Maurício Nogueira (Orientador); Casarejos, Fabrício (Co-orientador); Rufin, Carlos (Co-orientador). Embalagens compostáveis: uma estratégia para a redução de impacto ambiental. Rio de Janeiro, 2015. 93p. Dissertação de Mestrado - Programa de PósGraduação em Metrologia (Área de concentração: Metrologia para Qualidade e Inovação), Pontifícia Universidade Católica do Rio de Janeiro.

Propõe-se desenvolver uma metodologia para metrificar e monetizar o ciclo de vida de um produto industrial e validá-la pela sua aplicação a um caso real: a comparação entre dois tipos de embalagens descartáveis, copos de matéria-prima de fonte renovável (mandioca) e copos de plástico. Motiva o estudo a constatação de que o sistema industrial, ao longo do ciclo de vida dos produtos, até o seu consumo e descarte, ainda não conseguiu adotar um modelo circular de produção que maximize reutilização e reciclagem dos resíduos, bem como limite a emissão de gases de efeito estufa, o consumo excessivo de água e o descarte de rejeitos, fatores que ameaçam a sustentabilidade planetária. Dessa ameaça resulta uma responsabilidade compartilhada entre sociedade e governo sobre esses fatores, refletida em especial na Política Nacional de Resíduos Sólidos. Para as empresas, impõe-se medir e valorar o ciclo completo do produto, "da terra à terra", incluindo logística reversa, responsabilidade estendida de produto e custo ambiental. Nesse sentido, foram desenvolvidas equações para metrificação e monetização do ciclo dos produtos. Para validação, foram utilizados dados da empresa CBPAK, fabricante de copos de mandioca, e da BRASKEM, que produz matéria-prima para os copos de plástico. O estudo conclui que a metodologia é válida e pode ser replicada. A comparação entre os copos das duas origens mostram indicadores ambientais largamente favoráveis aos copos de mandioca e, do ponto de vista financeiro, com a aplicação do ciclo de vida completo, uma equalização de custos da ordem de $60 \%$ em relação aos preços sem consideração das externalidades.

\section{Palavras-chave}

Metrologia; Metrificação; Monetização; Resíduos sólidos; Custo ambiental; Sustentabilidade; Compostagem. 


\section{Abstract}

Bastos, Cláudio Rocha; Frota, Maurício Nogueira (Advisor); Casarejos, Fabrício Lopes Luiz (Co-advisor); Rufin, Carlos (Co-advisor). Compostable packaging: a strategy for reducing environmental impact. Rio de Janeiro, 2015. 93p. - MSc. Dissertation - Programa de PósGraduação em Metrologia (Área de concentração: Metrologia para Qualidade e Inovação), Pontifícia Universidade Católica do Rio de Janeiro.

The thesis proposes the development of a methodology for the metrification and monetization of the life cycle of an industrial product, and its validation by its application to an actual case: a comparison between two types of disposable packaging, cups of raw materials from renewable sources (cassava/manioc) and plastic cups. The motivation of the study is the finding that the industrial system throughout the life cycle of the product until its consumption and disposal, has yet to adopt a circular model of production that maximizes reuse and recycling of waste as well as limiting the emission of greenhouse gases, excessive water consumption and disposal of waste, factors that threaten planetary sustainability. These threats arise as a shared responsibility between society and government, reflected particularly in the National Solid Waste Policy of Brazil. For companies, it is necessary to measure and value the full product cycle, "earth to earth," including reverse logistics, extended product responsibility, and environmental cost. In this sense, equations were developed for metrication and monetization of the product cycle. For validation, company data were used from CBPAK, a manufacturer of cassava cups, and BRASKEM, a raw material producer for the plastic packaging industry. The study concludes that the methodology is valid and can be replicated. The comparison between the cups from the two sources shows environmental indicators largely favorable to cassava cups and, from a financial point of view, the application of full life cycle shows a cost equalization of the order of $60 \%$ compared to prices without consideration of externalities.

\section{Keywords}

Metrology; Metrification; Monetization; Solid waste; Environmental cost; Sustainability; Composting. 


\section{Sumário}

1 O ciclo de vida do produto e a sustentabilidade 13

$\begin{array}{ll}\text { 1.1. Contexto e relevância } & 13\end{array}$

1.2. A métrica do ciclo do carbono no ciclo de vida do produto 20

1.3. O desafio de metrificar e monetizar 22

1.4. Objetivos 24

1.4.1. Objetivo geral 24

1.4.2. Objetivos específicos 24

1.4.3. Dados e informações 24

1.5. Estrutura da dissertação 25

§ 2 O ciclo de carbono no ciclo de vida do produto no contexto das políticas ambientais brasileiras 26

2.1. Políticas públicas com foco no meio ambiente 26

2.2. A Política Nacional de Meio Ambiente 27

2.3. A Constituição e o meio ambiente 28

2.4. A Política Nacional de Educação Ambiental 31

2.5. A Política Nacional dos Resíduos Sólidos 33

3 Elementos externos que influenciam o ciclo de vida 41

3.1. As embalagens 41

3.2. Os resíduos sólidos e sua destinação 43

3.4. Polímeros, biodegradação e compostagem 45

3.5. Logística reversa e responsabilidade estendida ao produto 47

3.6. Custo ambiental 48

4 Modelagem do ciclo de vida dos copos descartáveis 50

4.1. Etapas e elementos do ciclo de vida 50

4.2. As matérias-primas 51

4.2.1. Mandioca $\quad 52$

4.2.2. Plástico 52 
4.2.3. Fontes de dados 53

4.3. Metrificação do ciclo do produto 58

4.3.1. Premissas para cálculo das emissões e da fixação de carbono 58

4.3.2. Equações para as emissões de Gases de Efeito Estufa 60

4.3.3. Emissão de Gases de Efeito Estufa 62

4.3.4. Métrica para a fixação de carbono 67

4.3.5. Balanço das emissões de GEE 68

4.3.6. Consumo de água 68

4.3.7. Balanço do consumo de água 69

4.4. Monetização do ciclo do produto 70

4.4.1. Princípio da substituição 70

4.4.2. Indicadores de impacto ambiental 70

4.4.3. Neutralização de carbono $\quad 70$

4.4.4. Água de processo $\quad 71$

4.4.5. Áreas em aterros sanitários $\quad 71$

4.4.6. Custos dos copos descartáveis 74

4.4.7. Valor monetário final 75

4.4.8. Custo ambiental $\quad 76$

4.4.9. Análise dos resultados 77

5 Conclusões 79

6 Referências Bibliográficas 82

Anexo I: Exposição de motivos da PNRS 84

$\begin{array}{ll}\text { Anexo II: Glossário } & 91\end{array}$ 


\section{Lista de tabelas}

Tabela 1 - Panorama dos Resíduos Sólidos Urbanos (RSU) - $2012 \quad 44$

Tabela 2 - Destinação final em volume diário de resíduos sólidos $\quad 45$

Tabela 3 - Emissões de GEE do plantio à colheita da mandioca 62

Tabela 4 - Emissões de GEE no beneficiamento da mandioca nas fecularias

63

Tabela 5 - Emissões de GEE no transporte 64

Tabela 6 - Emissões de GEE no consumo de energia 65

Tabela 7 - Emissões totais de $\mathrm{CO}_{2}$ eq./copo em todo o processo 66

Tabela 8 - Comparativo das emissões de GEE 68

Tabela 9 - Consumo de água na produção dos copos descartáveis $\quad 69$

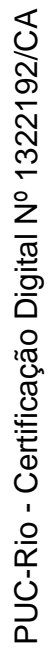

Tabela 10 - Valor monetário dos indicadores de impacto dos copos de mandioca

Tabela 11 - Valor monetário dos indicadores de impacto dos copos de plástico 


\section{Lista de figuras}

Figura 1 - Representação dos sistemas integrados no desenvolvimento sustentável

Figura 2 - Fronteiras planetárias e indicadores do estágio (Rockstrom, 2009) -

Figura 3 - Ciclo de vida do produto, da origem ao sumidouro

Figura 4 - O ciclo de vida do produto na economia circular: Exemplo do copo de mandioca

Figura 5 - Etapas do ciclo de vida dos copos descartáveis de mandioca

Figura 6 - Etapas do ciclo de vida dos copos descartáveis de plástico

Figura 7- Máquina de termoexpansão de produção de copos da CBPAK

Figura 8 - Copos compostáveis de mandioca da CBPAK

Figura 9 - Produtos da CBPAK

\section{Lista de quadros}

Quadro 1 - Indicadores ambientais do estudo comparativo

Quadro 2 - Comparativo, com compostagem dos copos de mandioca 


\section{Siglas e abreviações}

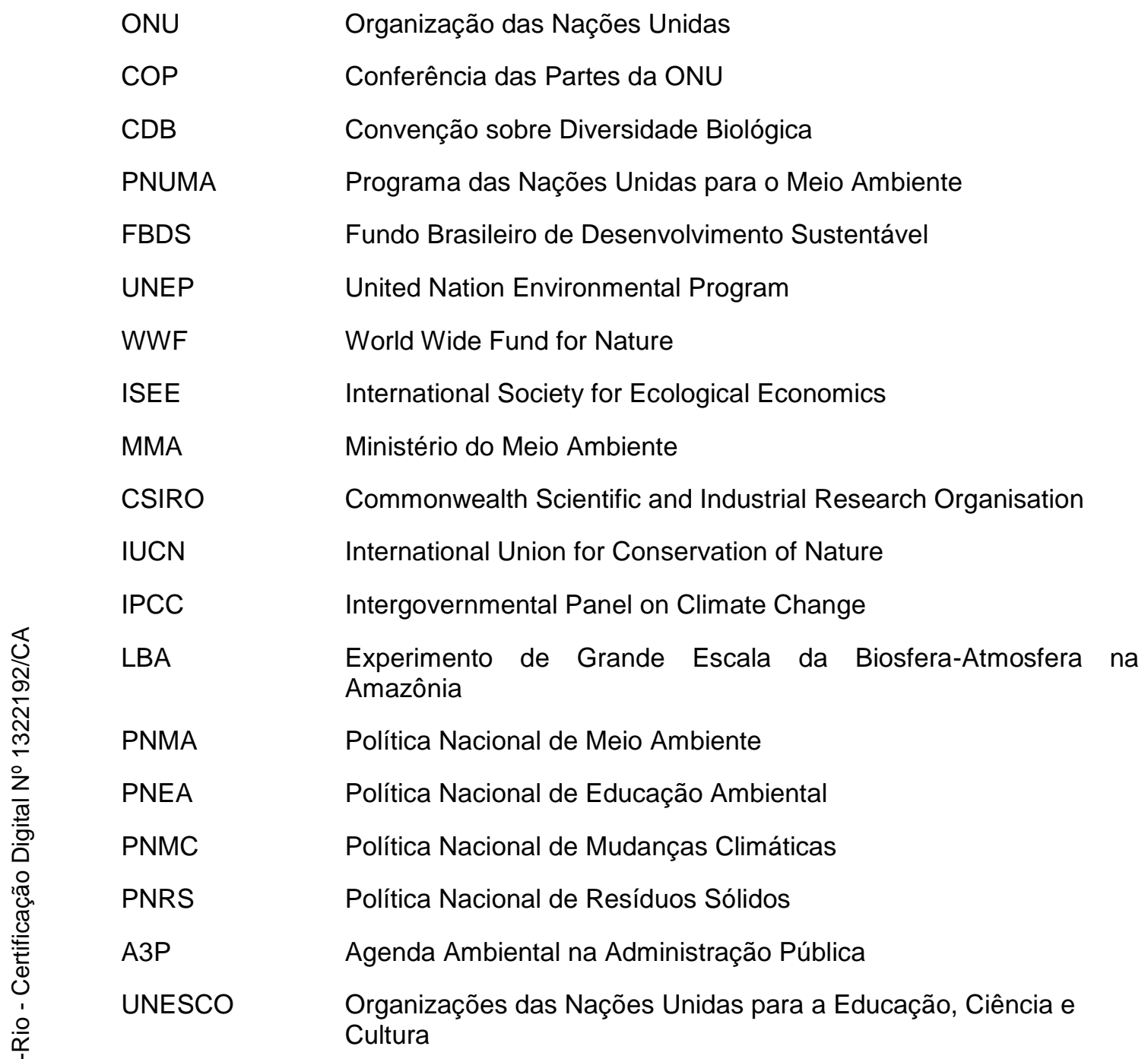




\section{O ciclo de vida do produto e a sustentabilidade}

1.1.

\section{Contexto e relevância}

Desenvolvimento Sustentável é um conceito hoje consolidado. Expressa a ideia de que o desenvolvimento da sociedade está indissoluvelmente ligado à sustentabilidade planetária e às suas fronteiras (Rockstrom et al., 2009).

O tema deve ser entendido como uma perseguição intelectual que prioriza o respeito ao ser humano e a integração social, mas é conectado com o crescimento econômico e o desenvolvimento tecnológico. Integra quatro complexos sistemas: (i) a economia mundial; (ii) a sociedade global; (iii) o meio ambiente; (iv) as políticas públicas.

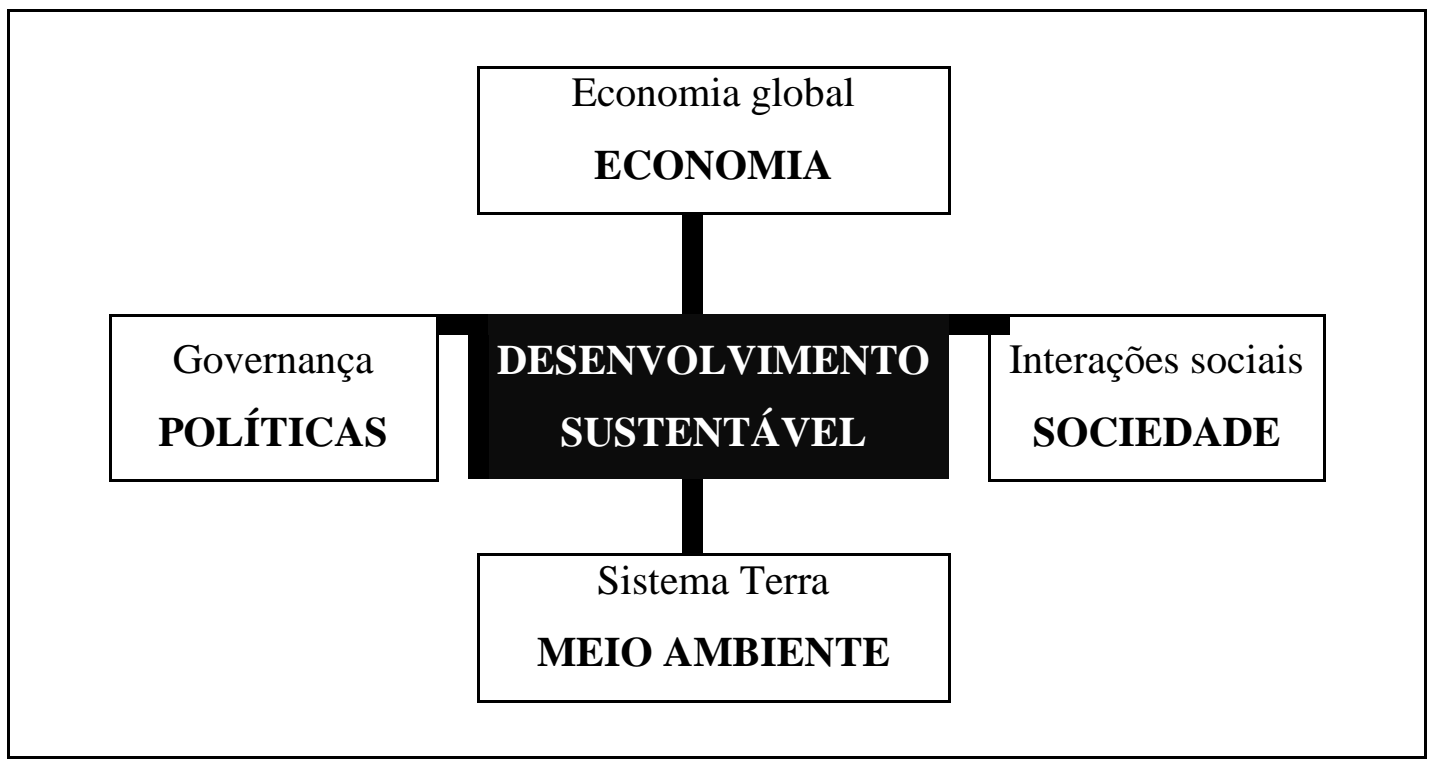

Figura 1 - representação dos sistemas integrados no desenvolvimento sustentável

Segundo Jeffrey Sachs (2015), diretor do Earth Institute da Universidade de Columbia (EUA), o desenvolvimento sustentável engloba:

- $\quad$ Prosperidade econômica

- $\quad$ Inclusão e coesão social

- $\quad$ Sustentabilidade ambiental

- Boas práticas de governança (governo e iniciativa privada) 
A ONU (Organizações das Nações Unidas) têm sido fundamental no trato do assunto. Em 1982, instituiu a Comissão Mundial sobre o Meio Ambiente, que, até os dias de hoje, promove reuniões anuais da Conferência das Partes - COP, órgão supremo da Convenção sobre Diversidade Biológica - CDB. A representatividade da COP é inquestionável: dela participam delegações oficiais dos 188 membros da CDB - 187 países e um bloco regional -, observadores de países não partes e outros, representantes dos principais organismos internacionais, de organizações acadêmicas e empresariais e da sociedade civil, lideranças indígenas e imprensa. Desde que a Convenção entrou em vigor em 29 de dezembro de 1993 (adotado como Dia Mundial da Biodiversidade pela ONU), já foram realizadas vinte reuniões da COP.

Nesse foro privilegiado, renomados pesquisadores e pensadores encontram uma tribuna livre para apresentar os seus trabalhos. A contribuição da comunidade científica para a preservação ambiental e a inclusão social é reconhecida e traduzida em ações práticas, por meio de movimentos como a Sustainable Development Solution Network (RSDS), do Earth Institute da Universidade de Columbia (EUA) e da Fundação Brasileira para o Desenvolvimento Sustentável (FBDS).

O desenvolvimento sustentável é um conceito que vem de muito longe no passado, mesmo que tenha sido sem a formalização nos termos em que hoje é empregado. Com efeito, em 1798, Thomas Malthus, economista e demógrafo britânico, já assim se manifestava: “(...) The power of population is superior to the power of the Earth to produce subsistence for man, that premature death must in some shape or other visit the human race. (...)" (Malthus, 1798, p.61). Data de pelo menos dois séculos, portanto, a preocupação com as ações do ser humano em relação à capacidade da natureza de obter equilíbrio em seus processos de recomposição natural.

Entretanto, se as manifestações de preocupação sobre o estado da natureza são antigas, foi apenas no final do século XX que entidades mundiais representativas iniciaram um forte movimento em favor de um desenvolvimento econômico que a um tempo fosse ordenado e que respeitasse o meio ambiente.

Exemplo disso veio do Clube de Roma "uma associação informal de lideranças da política, dos negócios e das ciências interessadas em contribuir de 
forma sistêmica, interdisciplinar e holística para um mundo melhor". Caracterizado pela imparcialidade, o Clube não expressa qualquer ponto de vista particular, seja ideológico, seja político ou nacional, e, nos seus mecanismos de gestão, não tem cargos eletivos. Seus associados estão unidos pela convicção de que os grandes problemas que desafiam a humanidade são de tamanha complexidade que os planos de ação tradicionais já não são capazes de superá-los, nem mesmo de enfrentá-los em seu conjunto.

O Clube despertou considerável atenção pública com seu relatório "Limites do Crescimento" (Limits to growth). Na forma de livro (Meadows et al., 1972), o texto teve 30 milhões de exemplares distribuídos, em mais de 30 traduções, fazendo dele o livro sobre meio ambiente mais vendido na história mundial (fonte: https://en.wikipedia.org/wiki/Club_of_Rome, acessada em 17/07/2015, 10h30). Foi grande a repercussão internacional desse estudo, principalmente no debate caloroso que ocorreu, no mesmo ano de 1972, na Conferência das Nações Unidas sobre o Ambiente Humano, conhecida como Conferência de Estocolmo.

Basicamente os autores apontavam para três situações: (i) se a atual tendência de crescimento continuasse imutável, os limites de crescimento no planeta seriam alcançados em menos de cem anos. O resultado mais provável seria um declínio súbito e incontrolável tanto da população quanto da capacidade industrial; (ii) modificando-se essa tendência de crescimento e formando-se uma condição de estabilidade ecológica e econômica, o estado de equilíbrio global poderia ser planejado de tal modo que as necessidades materiais básicas de cada pessoa na Terra poderiam ser satisfeitas e cada pessoa poderia ter igual oportunidade de realizar seu potencial humano individual; (iii) se a população do mundo decidisse empenhar-se em obter esse segundo resultado, em vez de lutar pelo primeiro, quanto mais cedo começasse a trabalhar para alcançá-lo, maiores seriam suas possibilidades de êxito.

Logo surgiram várias críticas, em diversas áreas. Entre os teóricos que defendiam as teorias do crescimento destacou-se Robert Solow, Prêmio Nobel em Economia de 1987, que criticou com veemência os prognósticos catastróficos do Clube de Roma (Solow, 1973 e 1974). Também intelectuais de países subdesenvolvidos manifestaram-se de forma crítica. Mahbub ul Haq (1976) levantou a tese de que as sociedades ocidentais, depois de um século de crescimento industrial acelerado, defendiam o congelamento do crescimento com 
a retórica ecologista, que atingiria de forma direta os países pobres, que continuariam nessa condição.

Significativa contribuição foi também oferecida pela World Conservation Strategy, com a publicação "Living resouses conservation for sustainable development", datada de 1980 - trabalho encomendado pela IUCN (International Union for Conservation of Nature and Natural Resources), ${ }^{1}$ com a cooperação financeira da UNEP (United Nations Environmet Program) e do WWF (World Wildlife Fund for Nature). O trabalho propunha que o desenvolvimento sustentável fosse gerenciado de forma a conservar os recursos naturais e serviu de base para subsequentes políticas ambientais internacionais. Nele, o termo desenvolvimento sustentável foi usado como um objetivo a ser alcançado por meio da conservação dos recursos vivos e da manutenção tanto da diversidade genética quanto dos processos ecológicos.

Em outra vertente, Herman Daly (um dos principais teóricos da Economia Ecológica, fundador da International Society for Ecological Economics - ISEE), em seu livro Beyond growth (1996), reporta uma inusitada situação. Por ocasião da elaboração do relatório "Desenvolvimento e Meio Ambiente", do Banco Mundial, em 1992, ele criticou o que vinha sendo produzido e sugeriu a inserção de um gráfico no qual a economia aparecia como subconjunto de um conjunto maior que representava o ecossistema responsável não só por fornecer os insumos para as atividades econômicas, mas também por receber os dejetos que essas atividades produziam. A proposta gerou tanta polêmica que a equipe terminou por eliminar do relatório as menções ao ecossistema. Para Daly, o Banco Mundial não estava pronto para aceitar limites ao crescimento, receitado para todos os desajustes da economia, inclusive para os males da pobreza.

Sobre o assunto, em entrevista à revista Época Negócios em 20 de julho de 2010, Daly respondeu a uma pergunta sobre as mudanças no padrão da escassez da seguinte forma:

\footnotetext{
${ }^{1}$ A União Internacional para Conservação da Natureza (International Union for Conservation of Nature - IUCN), organização dedicada à conservação dos recursos naturais, é filiada à UNESCO. Reúne 84 nações, 112 agências de governo, 735 ONGs e milhares de especialistas e cientistas de 181 países, estando entre as principais organizações ambientais do mundo. Sua missão é influenciar, encorajar e assistir sociedades em todo o mundo na conservação da integridade e biodiversidade da natureza e assegurar que todo e qualquer uso dos recursos naturais seja equitativo e ecologicamente sustentável. (Fonte: http://www.iucn.org/, acessado em 16/07/2015, 15h15).
} 
Os economistas são treinados para se preocuparem com a escassez. Num mundo vazio, o que é escasso é o trabalho humano e o capital. Abundantes são os recursos naturais. Para maximizar a produtividade do capital e do trabalho, usamos os recursos naturais o mais rápido possível. Em um mundo cheio, o padrão de escassez mudou. Veja o exemplo dos peixes. O fator determinante no passado para o limite do número de peixes pescados por ano era o número de barcos e de pescadores. Mais pescadores e mais barcos resultavam em mais peixes. Isso não é verdade hoje. Já temos pescadores e barcos demais, e o fator limitante é o número de peixes no oceano. O limite é o capital natural. Por isso, temos que dar tempo para os peixes se recuperarem.

"Daly, 1996”

Ainda no tema dos limites do crescimento, Graham Turner, da "Commonwealth Scientific and Industrial Research Organisation" (CSIRO, Austrália), revisitou em 2008 o trabalho original do Clube de Roma e publicou o artigo "Uma comparação de 'Os Limites do Crescimento' com trinta anos de realidade" (Turner, 2008). Reafirmou então que as mudanças verificadas na industrialização, na produção de alimentos e na poluição estavam todas coerentes com as previsões originais e que permanecia a ameaça de um colapso econômico e social ainda no século XXI.

Numa visão mais proativa, Johan Rockstrom - diretor executivo e pesquisador do Stockholm Resilience Centre (centro da Universidade de Estocolmo, Suécia, dedicado ao estudo da resiliência de sistemas socioecológicos) - propôs uma nova abordagem para sustentabilidade e desenvolvimento global, uma que construísse avançados conceitos e conhecimento nas áreas dos limites do crescimento, dos seus elementos críticos e da capacidade de suporte do planeta (Rockstrom et al., 2009). Avançou o conceito do que chamou de fronteiras planetárias e propôs nove fronteiras, os Processos do Sistema Terra (Fig. 2):

1) Mudanças climáticas;

2) Taxa da perda da biodiversidade terrestre e marítima;

3) Carregamento biogeoquímico, ciclo global de nitrogênio e fósforo;

4) Redução ou esgotamento do ozônio;

5) Acidificação dos oceanos;

6) Uso de água potável;

7) Mudança do sistema terrestre, uso da terra;

8) Poluição química;

9) Carga de aerossóis na atmosfera. 


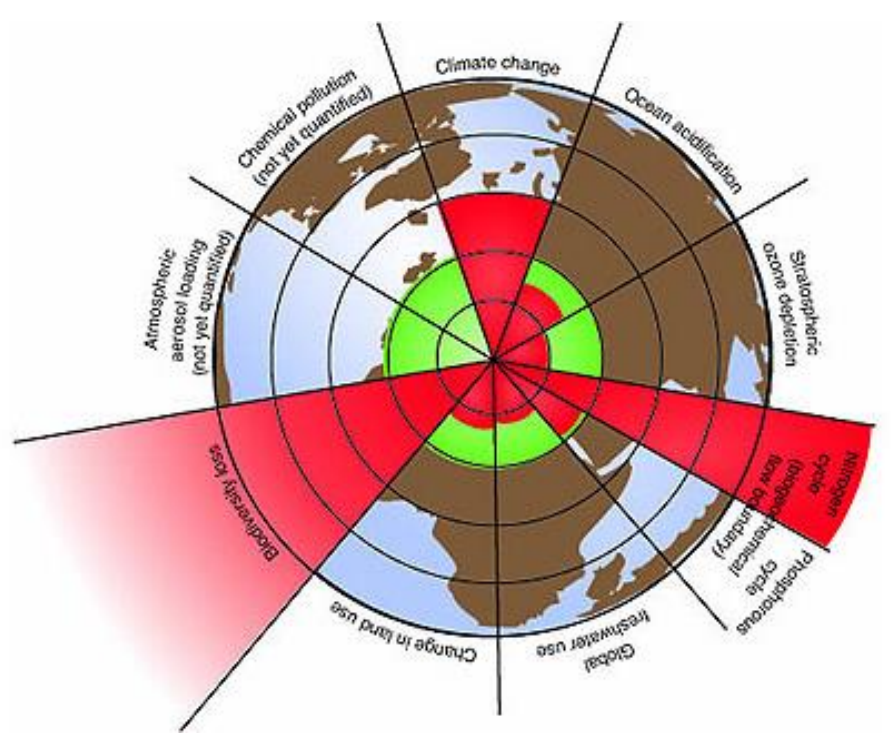

Figura 2 - fronteiras planetárias e indicadores do estágio (Rockstrom, 2009) -

A proposta apoia-se em três pilares. O primeiro, o de se definir précondições para o desenvolvimento humano; o segundo, o de se ultrapassar certos limiares da biofísica, o que pode trazer consequências desastrosas para a humanidade; e, terceiro, o que sinaliza com intensidade para o fato de que três dos nove processos do Sistema Terra já ultrapassaram seus limites. Segundo o autor:

[...] vencer o desafio de se manter o Holoceno [época do período Quaternário da era Cenozoica que se iniciou há cerca de 11,5 mil anos e se estende até o presente], isto é, tomar ações que permitem o desenvolvimento humano na visão sustentável.

Por outro lado, Amory Lovins (físico americano, diretor do Rocky Mountain Institute, Colorado - EUA, uma organização que atua no campo da sustentabilidade, com foco em inovações lucrativas para eficiência energética e de recursos - www.rmi.org), em seu livro Capitalismo Natural (2010), afirma:

Um dos ciclos mais críticos da natureza é a troca continua de dióxido de carbono por oxigênio entre plantas e animais. A natureza presta gratuitamente esse "serviço de reciclagem". Na atualidade, porém, está se formando dióxido de carbono na atmosfera devido, em parte, à queima de combustíveis fósseis. $\mathrm{O}$ resultado é que a capacidade do sistema natural de reciclar o dióxido de carbono foi excedida, do mesmo modo que a pesca excessiva pode exceder a capacidade de a área de pesca ter o estoque reposto. No entanto, é particularmente importante perceber que não se conhece nenhuma alternativa para o serviço natural do ciclo de carbono (p.4).

Várias e diversas, portanto, são as discussões, contribuições, críticas. Muito oportunamente, o Papa Francisco, o chefe da Igreja Católica, engrandece o debate 
na recente encíclica 'Laudato si' (2015). Entre muitos outros e detalhados elementos, diz: "13. O urgente desafio de proteger a nossa casa comum inclui a preocupação de unir toda a família humana na busca de um desenvolvimento sustentável e integral, pois sabemos que as coisas podem mudar".

Pode-se, assim, aceitar com reservas os prognósticos de um declínio súbito e incontrolável do sistema natural e do sistema econômico. O caminho apontado é buscar um estado de equilíbrio global planejado. Um ceticismo saudável é também comungar com o pensamento consciente de que o apoio ao desenvolvimento sustentável nem sempre envolve mobilização de recursos adicionais. Novas metodologias, novas lógicas de um pensamento cognitivo podem criar novos conhecimentos.

Para Alier (1998, p.271), a rota para se encontrar uma sociedade ecológica não passa somente por políticas públicas de controles e regulamentações nas ofertas de bens e serviços, mas também pela alteração dos padrões de consumo. $\mathrm{O}$ consumidor moderno, como definido por Kotler e outros (2010), mudará seus hábitos e migrará para produtos ecológicos, que gerem externalidades positivas (menores impactos ambientais). Ele propõe que uma boa política ambiental poderia apoiar grupos de consumidores cujos estilos de vida antecipassem um futuro mais equilibrado ecologicamente e assim chegar a acordos para apoiar suas práticas.

Fala-se em economia ambiental, em economia ecológica e nos fundamentos teóricos que abordam estas questões. São coisas semelhantes, mas distintas quando se interpreta a relação economia/natureza para garantir o desenvolvimento sustentável. Na economia ambiental, os recursos naturais são tratados como infinitamente substituíveis por trabalho ou capital reprodutível. A sustentabilidade é vista como o principal fator para manter a capacidade produtiva da sociedade. Já na economia ecológica defende-se que existem limites para o uso dos recursos, que são finitos. Nessa ótica estão as linhas do pensamento teórico declaradas por Meadows, que propõe um crescimento material zero para permitir que se estabeleça uma sociedade sustentável, o que é contestado por Solow.

Nesse quadro, a grande contribuição do conceito de desenvolvimento sustentável para a sociedade foi avançar pelo caminho do meio, ou seja, conciliar abordagens entre posturas antagônicas extremas, entre desenvolvimentistas e preservacionistas. Define-se “desenvolvimento" como eficiência econômica, 
equilíbrio ambiental e equidade social, e "sustentável" como a possibilidade das gerações futuras atenderem as suas próprias necessidades (Amazonas, 2007).

Pensar em sustentabilidade, então, é pensar em perpetuidade. O entrelaçamento entre as gerações, onde a atual geração é herdeira de comportamentos, hábitos e práticas de gerações passadas, que não tinham a preocupação da preservação ambiental e seus costumes. Agora, essa mesma geração se vê diante do compromisso de deixar como legado para as futuras gerações um mundo mais sustentável, em suas quatro dimensões (ambiental, econômica, social e cultural).

E garantir um desenvolvimento sustentável pressupõe, modernamente, assegurar uma sociedade sustentável, isto é, dentro de uma cosmovisão em que Terra e seres humanos emergem como uma única entidade, não mais segundo uma visão antropocêntrica, que coloca o homem como o centro de toda a natureza, como consumidor de recursos naturais tidos como infinitos.

\section{2.}

\section{A métrica do ciclo do carbono no ciclo de vida do produto}

Os impactos da ação do homem sobre o ambiente na era industrial já resultaram em muitas alterações. São reais as mudanças do clima, a ameaça de escassez de água potável e o crescimento contínuo da quantidade de resíduos sólidos gerados. Os efeitos dessas alterações já estão sendo sentidos pela sociedade em todos os setores, como saúde, transporte, agricultura, pecuária, indústria, comércio e finalmente na economia como um todo. É necessário, portanto, se pensar em sustentabilidade.

Não se pode, porém, considerar a sustentabilidade apenas sob a ótica do cliente consumidor. Há que ter em conta a participação da indústria, do comércio e dos serviços, pois sua própria sobrevivência depende disso, em um mercado constituído por cidadãos cada vez mais conscientes tanto das suas próprias responsabilidades ambientais, quanto das responsabilidades dos demais entes sociais. Logo, produtos e serviços também devem seguir boas práticas de manejo ligadas ao meio ambiente e considerar o ciclo de carbono no completo ciclo de vida dos produtos, desde a sua origem, na obtenção da matéria prima, passando pela produção, consumo e descarte, até o seu destino final no sumidouro 


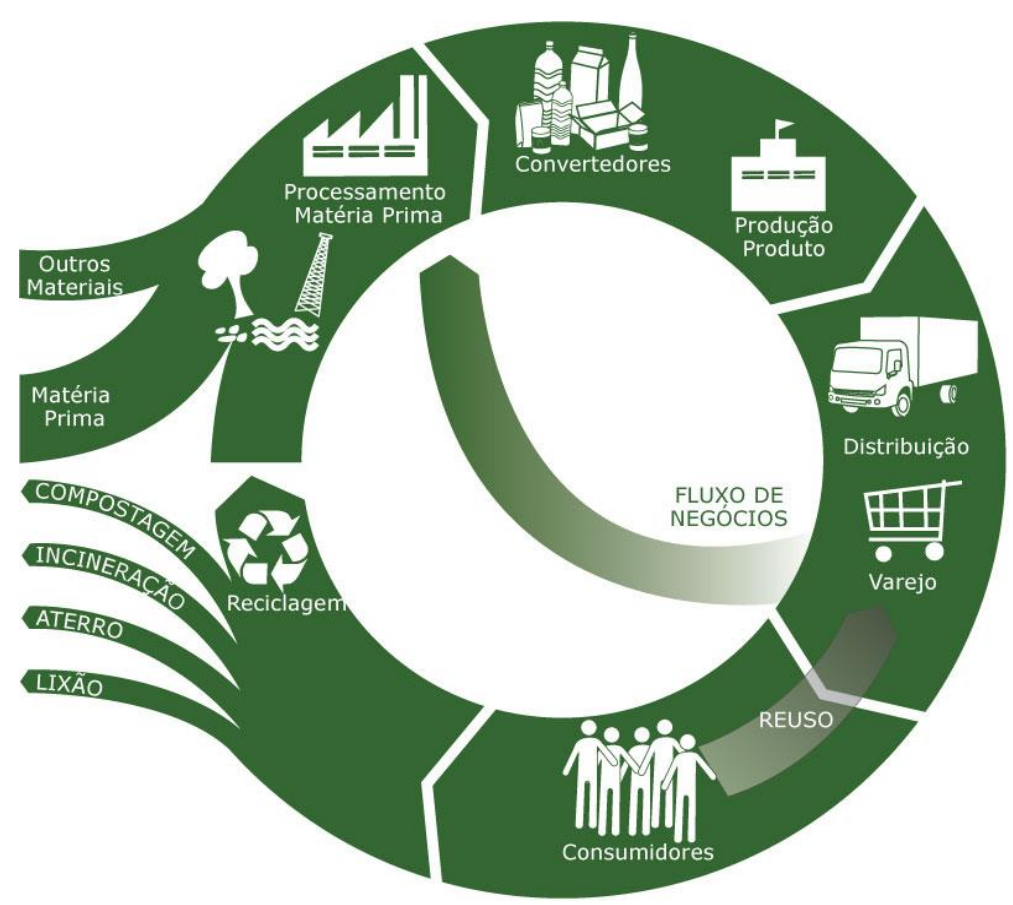

Figura 3 - ciclo de vida do produto, da origem ao sumidouro

Fonte: www.abes-org.sp.com.br

Numa visão bem atual e inovadora, o Clube de Roma publicou, em 2015, um relatório preliminar intitulado "The Circular Economy and Benefits for Society. Swedish Case Study Shows Jobs and Climate as Clear Winners", assinado por Anders Wijkman e Kristian Skanberg (2015). O tema central do relatório é o conceito de "economia circular", em contraposição à tradicional “economia linear". Nesta, a origem (matéria prima) alinha-se com a produção, o consumo e o descarte. Naquela, segundo os autores, na medida em que a sociedade, incentivada por políticas públicas com foco na sustentabilidade, retorna o produto do descarte para o sistema produtivo, a consequência positiva nos indicadores de impacto ambiental é imediata. E o que seria esse "ciclo completo"? Na ótica da economia circular, trata-se do conceito "da terra à terra".

A responsabilidade empresarial - e social - do empreendedor, portanto, não começa apenas no momento em que a matéria prima entra na fábrica e não termina assim que o seu produto é comercializado. Vem desde antes, desde a produção da matéria prima, e vai até o destino final, em que a matéria volta ao 
sistema produtivo - por recuperação, reciclagem, compostagem ou aproveitamento energético - ou é adequadamente encaminhada como rejeito.

Empresários, entretanto, lidam com inúmeros compromissos concorrentes: produção, compras, vendas, prazos, pagamentos, fluxos financeiros, custos, margens e tantos outros. Em comum, todos precisam ser correta e precisamente quantificados, para sucesso do empreendimento. Logo, é necessidade inescapável da empresa medir e atribuir valor ao ciclo completo do produto, segundo o conceito de que "não se pode gerenciar o que não se pode medir", pensamento originalmente enunciado por Lorde Kelvin (título de nobreza do cientista inglês William Thomson, 1883)², largamente difundido em áreas como Administração, Economia e Análise de Sistemas.

A questão que se coloca, portanto, é a do que fazer para responder à demanda pela metrificação e monetização do ciclo completo de um produto.

\section{3. O desafio de metrificar e monetizar}

Como então abordar o desafio de medir e atribuir valor monetário ao ciclo completo de um produto? A diversidade entre os muitos tipos de produto é enorme, os seus ciclos são igualmente diversos e os dados disponíveis são precários para o fim em vista, pois mesmo o conceito de ciclo completo de produto, "da terra à terra", ainda não está totalmente absorvido no dia a dia das empresas, pelo que faltam experiências e dados.

O primeiro passo apoia-se em um aspecto peculiar: cerca de 1/5 do material descartado é composto por embalagens (BRASIL - MMA, 2005). São 25 mil toneladas de embalagens que vão parar, todos os dias, nos depósitos de lixo. Para dar uma imagem da dimensão do problema: somente as embalagens, desconsideradas todas as demais formas de material descartado, poderiam encher

\footnotetext{
${ }^{2}$ I often say that when you can measure what you are speaking about, and express it in numbers, you know something about it; but when you cannot express it in numbers, your knowledge is of a meagre and unsatisfactory kind; it may be the beginning of knowledge, but you have scarcely, in your thoughts, advanced to the stage of science, whatever the matter may be. (Lorde Kelvin. In: Lectures on Electrical Units of Measurement. London: Popular Lectures Vol. I, p.73, 1883). (Eu digo frequentemente que quando você pode medir aquelo do que você está falando, e expressá-lo em números, já está sabendo algo disso; mas quando não pode expressá-lo em números, o seu conhecimento e pouco e insatisfatório; pode ser um começo de conhecimento, mas você apenas avançou, no seu pensamento, para o estágio da ciência, seja o que for a questão) [Tradução do autor].
} 
mais de dois mil caminhões de lixo, que ocupariam quase 20 quilômetros de estrada, diariamente!

Tendo-se como razoavelmente constante essa relação, a modelagem do ciclo das embalagens descartáveis pode, portanto, ser instrumental para generalizações, que poderão vir a ser de grande utilidade para muitos outros casos. Não obstante, mesmo limitando o escopo do estudo às embalagens descartáveis, o problema ainda é de uma dimensão de difícil tratamento quantitativo.

Adota-se, pois, como um segundo passo, o recorte a apenas um tipo de embalagens descartáveis - copos. Para esses, há dados suficientes para uma análise de dois tipos de produtos, fabricados a partir de matérias primas diferentes, uma de fonte fóssil - petróleo - e outra, de fonte renovável, a mandioca. Nessa visão, a representação do ciclo de vida do produto evolui da visão mostrada na Fig. 3 para outra, mais completa, coerente com a economia circular propugnada pelo Clube de Roma, exemplificada para o caso desta dissertação-copos de mandioca—na Figura 4:

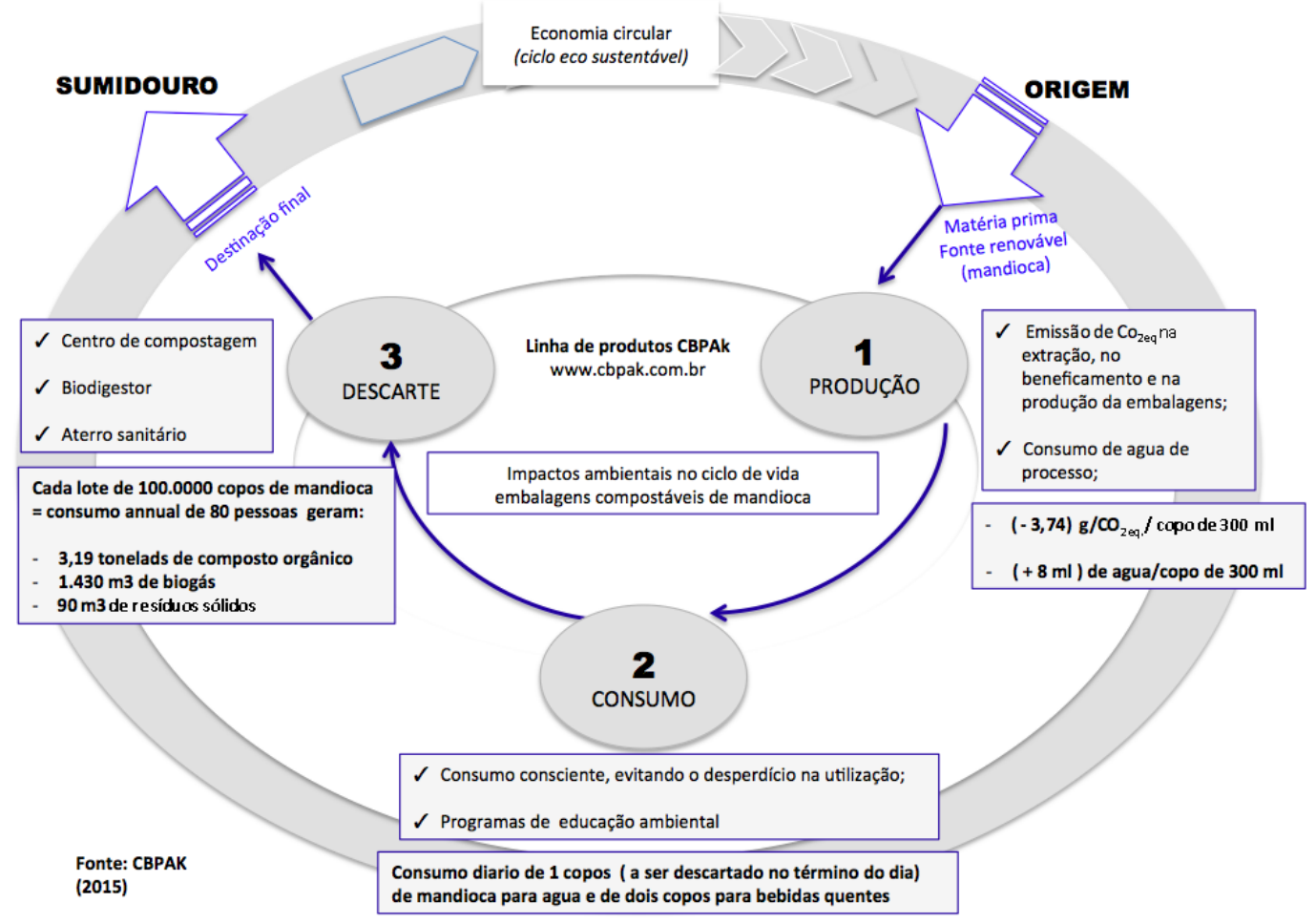

Figura 4 - o ciclo de vida do produto na economia circular: Exemplo do copo de mandioca 


\section{4. \\ Objetivos}

A partir, então, do interesse em metrificar e monetizar o ciclo completo de um produto industrial - no caso, embalagens descartáveis de dois tipos, copos de plástico e copos compostáveis de mandioca -, com as simplificações propostas como necessárias para modelar o fluxo, formulam-se os objetivos do presente trabalho.

\subsection{1.}

Objetivo geral

Propor uma metodologia de metrificação e monetização do ciclo de vida de um produto industrial e aplicá-la a um caso real comparativo, de embalagens descartáveis de plástico e de mandioca.

\subsection{2.}

Objetivos específicos

1) Inventariar e comparar as emissões de Gases de Efeito Estufa (GEE) e o consumo de água entre copos de plástico e copos de mandioca;

2) Propor um modelo de monetização para o ciclo de vida de embalagens descartáveis;

3) Quantificar o custo ambiental para a inclusão no custo total das embalagens descartáveis;

4) Identificar as rotas de destinação final da geração, tratamento e destinação final dos resíduos sólidos de embalagens descartáveis;

5) Contribuir com conhecimentos para a consolidação de uma educação ambiental voltada ao uso e descarte de embalagens.

\subsection{3.}

\section{Dados e informações}

A fonte de dados e informações para os copos descartáveis compostáveis é a empresa CBPAK Tecnologia S/A, líder e pioneira na produção de embalagens compostáveis (www.cbpak.com.br). Para os copos descartáveis de plástico, os dados foram obtidos pela BRASKEM, empresa brasileira do setor de química (www.braskem.com.br), para um estudo da empresa Green Domus (www.greendomus.com.br), empresa especializada em inventário de carbono, 
acreditada junto ao INMETRO - Instituto Nacional de Metrologia, Qualidade e Metrologia.

As muitas variáveis a serem consideradas nas fases do processo - produção, consumo e descarte - são levadas em consideração e interconectadas com a sustentabilidade nas suas quatro dimensões (ambiental, cultural, social e econômica). O ciclo de vida dos produtos é monetizado em termos de sequestro de carbono, de consumo hídrico e de efeitos do descarte, para copos dos dois tipos distintos de matéria-prima.

\section{5.}

\section{Estrutura da dissertação}

No Capítulo 1 contextualiza-se o tema e se estabelece a sua relevância, a partir do que são fixados os objetivos do trabalho.

O Capítulo 2 resume os aspectos da legislação aplicável ao desenvolvimento sustentável pertinentes aos objetivos do trabalho. A exemplo das ações promovidas pela ONU e por suas agências na área ambiental, também o Brasil criou a sua própria legislação nesta área. O destaque é a Política Nacional de Resíduos Sólidos.

O Capítulo 3 descreve sobre os elementos externos que influenciam o ciclo de vida e descreve alguns conceitos básicos, como embalagens, resíduos sólidos e sua destinação, polímeros, biodegradação e compostagem, logística reversa e EPR e custo ambiental.

O Capítulo 4 apresenta o modelo de metrificação e monetização do ciclo de vida do produto aplicado a copos descartáveis das duas origens consideradas, uma fóssil e, outra, orgânica. Neste capítulo são discutidos os resultados obtidos.

O Capítulo 5 apresenta as conclusões do estudo.

Acrescentam-se dois anexos: a Exposição de Motivos do Ministério do Meio Ambiente sobre a Política Nacional dos Resíduos Sólidos e um glossário com termos que são definidos ao longo da dissertação. 


\section{2 \\ O ciclo de carbono no ciclo de vida do produto no contexto das políticas ambientais brasileiras}

\section{1. Políticas públicas com foco no meio ambiente}

O Estado brasileiro de longa data mostra-se bastante sensível ao quadro de ameaça à sustentabilidade planetária e aos seus reflexos regionais. As mudanças climáticas, a ameaça de escassez de água potável e o crescimento da quantidade de resíduos sólidos são apenas alguns dos aspectos que trazem consequências já hoje, não em algum abstrato futuro remoto. No Brasil, basta observar a devastação contínua dos principais biomas - Floresta Amazônica, Cerrado, Mata Atlântica - e a escassez de água nas principais concentrações urbanas, de São Paulo, Rio de Janeiro e Belo Horizonte, por exemplo, bem como nas bacias hidrográficas, em especial da do Rio São Francisco que abastecem muitos reservatórios de usinas hidrelétricas nacionais.

A preocupação governamental manifesta-se por muitos canais, em planos diversos: a hospedagem de relevantes eventos internacionais: a Conferência das Nações Unidas sobre Meio Ambiente e Desenvolvimento, conhecida como Cúpula da Terra (Rio-92), a Conferência das Nações Unidas sobre Desenvolvimento Sustentável (Rio+20); a participação ativa em fóruns internacionais ligados às mudanças climáticas (IUCN, IPCC); iniciativas científicas como o Experimento de Grande Escala da Biosfera-Atmosfera na Amazônia (LBA) $)^{3}$.

No plano interno, como desdobramento que corrobora a atenção do governo, a criação de legislação e de políticas públicas específicas, desde a pioneira Lei ${ }^{\circ}$ 6.938 (Dispõe sobre a Política Nacional do Meio Ambiente - PNMA, lei promulgada em 1981, seguidamente atualizada) até a própria Constituição Federal de 1988. A essas, seguiram-se muitos outros diplomas legais, em especial a Lei ${ }^{\circ}$

\footnotetext{
${ }^{3}$ Informações em http://www.canalciencia.ibict.br/pesquisa/0117-Projeto-LBA.html, acessado em 27/07/2015, 16h30.
} 
9.795/1999 (Institui a Política Nacional de Educação Ambiental), a Lei n 12.187/2009 (Institui a Política Nacional sobre Mudança do Clima - PNMC) e a Lei n ${ }^{\circ}$ 12.305/2010 (Institui a Política Nacional de Resíduos Sólidos - PNRS).

A sensibilidade do governo está, portanto, bem patente, e configura um aspecto altamente positivo, pouco comum no Brasil: o estabelecimento de uma real política de estado, acima e além dos mandatos governamentais sucessivos desde 1981, pelo menos, até os dias atuais.

\section{2.}

\section{A Política Nacional de Meio Ambiente}

Criada em 1981, a Política Nacional do Meio Ambiente (Lei no 6.938/1981) é um marco histórico no desenvolvimento do direito ambiental no Brasil. Entre outros aspectos, instituiu um importante mecanismo de proteção ambiental - o estudo prévio de impacto ambiental (EIA) e seu respectivo relatório (Rima), instrumentos modernos no contexto global.

A lei, entre outros tópicos, formula princípios que vêm a ser, no fundo, a essência do Desenvolvimento Sustentável, como se tem aqui discutido:

Art. $4^{0}$ - A Política Nacional do Meio Ambiente visará:

I - à compatibilização do desenvolvimento econômico social com a preservação da qualidade do meio ambiente e do equilíbrio ecológico;

[...]

VI - à preservação e restauração dos recursos ambientais com vistas à sua utilização racional e disponibilidade permanente, concorrendo para a manutenção do equilíbrio ecológico propício à vida;

$[\ldots]$

Formaliza ainda o estabelecimento de definições de algumas expressões de uso corriqueiro, dando início a um glossário "oficial” para a terminologia das questões ambientais no Brasil. São os seguintes verbetes (grifos do autor):

Art. $3^{\mathbf{o}}$ - Para os fins previstos nesta Lei, entende-se por:

I - meio ambiente, o conjunto de condições, leis, influências e interações de ordem física, química e biológica, que permite, abriga e rege a vida em todas as suas formas;

II - degradação da qualidade ambiental, a alteração adversa das características do meio ambiente;

III - poluição, a degradação da qualidade ambiental resultante de atividades que direta ou indiretamente: 
a) prejudiquem a saúde, a segurança e o bem-estar da população;

b) criem condições adversas às atividades sociais e econômicas;

c) afetem desfavoravelmente a biota;

d) afetem as condições estéticas ou sanitárias do meio ambiente;

e) lancem matérias ou energia em desacordo com os padrões ambientais estabelecidos;

IV - poluidor, a pessoa física ou jurídica, de direito público ou privado, responsável, direta ou indiretamente, por atividade causadora de degradação ambiental;

$\mathrm{V}$ - recursos ambientais: a atmosfera, as águas interiores, superficiais e subterrâneas, os estuários, o mar territorial, o solo, o subsolo, os elementos da biosfera, a fauna e a flora. (Redação dada pela Lei no 7.804, de 1989).

A poluição, portanto, como definida, inclui o lançamento no ambiente de matérias ou energia em desacordo com padrões ambientais estabelecidos, possível caso do descarte de elementos não degradáveis ou sem nenhuma forma de reaproveitamento, ponto a ser discutido adiante.

\section{3. \\ A Constituição e o meio ambiente}

Seguindo a pioneira Política Nacional do Meio Ambiente, a Constituição Federal de 1988 inclui a temática ambiental. De mais relevantes para os propósitos desta dissertação, assinalam-se o Art. 23, nos seus incisos VI e VII, e o Art. 225, nos incisos V e VI do $\S 1^{\circ}$, a seguir reproduzidos:

Art. 23. É competência comum da União, dos Estados, do Distrito Federal e dos Municípios:

$[\ldots]$

VI - proteger o meio ambiente e combater a poluição em qualquer de suas formas;

VII - preservar as florestas, a fauna e a flora;

$[\ldots]$

Art. 225. Todos têm direito ao meio ambiente ecologicamente equilibrado, bem de uso comum do povo e essencial à sadia qualidade de vida, impondo-se ao poder público e à coletividade o dever de defendê-lo e preservá-lo para as presentes e futuras gerações.

$\S 1 .^{\circ}$ Para assegurar a efetividade desse direito, incumbe ao poder público:

[...]

V - controlar a produção, a comercialização e o emprego de técnicas, métodos e substâncias que comportem risco para a vida, a qualidade de vida e o meio ambiente; 
VI - promover a educação ambiental em todos os níveis de ensino e a conscientização pública para a preservação do meio ambiente; [...]

Como pontos mais relevantes, ressalta inicialmente a competência comum de todos os níveis federativos na proteção do meio ambiente, no combate à poluição e na preservação de florestas, fauna e flora - isto é, nenhum desses é tema exclusivo de apenas um dos entes. O meio ambiente deve ser protegido, concorrentemente, pela União, Estados, Distrito Federal e Municípios.

Em seguida, afirma que meio ambiente é um "bem de uso comum do povo", expressão configurada no Código Civil: “Art. 99. São bens públicos: I - os de uso comum do povo, tais como rios, mares, estradas, ruas e praças" (Lei $\mathrm{N}^{\circ}$ $10.406 / 2002)$.

O Art. 225 contempla ainda o dever do poder público e da coletividade de defender e preservar o meio ambiente para as presentes e futuras gerações (grifo do autor). Reafirmam-se, mais uma vez, o conceito de desenvolvimento sustentável e a responsabilidade compartilhada entre governo e sociedade. $\mathrm{Na}$ sequência, incumbe o poder público de controlar elementos que comportem riscos para o meio ambiente (entre outros) e de promover a educação ambiental e a conscientização para a preservação.

Esse artigo da Constituição motivou o desenvolvimento de uma agenda ambiental para a administração pública. Não seria ainda uma agenda ampla, aplicável a toda a sociedade brasileira, mas nem por isso menos importante, pelo alcance que pode ter, à vista o tamanho do aparato do governo, e pelo seu caráter pedagógico. De concreto, o Ministério do Meio Ambiente - MMA instituiu, em 1999, a denominada Agenda Ambiental na Administração Pública (A3P), com o objetivo básico de revisar os padrões de produção e consumo e a adotar novos referenciais de sustentabilidade ambiental nas instituições públicas.

A base para a A3P veio da Conferência da ONU sobre o Meio Ambiente e Desenvolvimento (ECO-92), que reforçou princípios e regras para o combate à degradação ambiental. Uma das principais conquistas da conferência foi a elaboração da Agenda 21, diretriz do desenvolvimento sustentável que concilia proteção ambiental, justiça social e eficiência econômica.

As diretrizes da A3P se fundamentam nas recomendações do Capítulo IV da Agenda 21, que indica aos países o estabelecimento de programas voltados ao exame dos padrões insustentáveis de produção e consumo e o desenvolvimento de 
políticas e estratégias nacionais de estímulo a mudanças nos padrões insustentáveis de consumo. Baseiam-se também no Princípio 8 da Declaração da Rio-92, que afirma que os Estados devem reduzir e eliminar padrões insustentáveis de produção e consumo e promover políticas demográficas adequadas.

Para operacionalizar as deliberações de governo, diversas providências foram tomadas. Em 2006, pelo Decreto $n^{\circ}$ 5.940, foi instituída a separação dos resíduos recicláveis descartados pelos órgãos e entidades da administração pública federal direta e indireta, bem como sua destinação às associações e cooperativas dos catadores de materiais recicláveis. Em 2008, foi estabelecida a inclusão de práticas de sustentabilidade ambiental nas compras públicas e foi instituído o Comitê de Implementação da A3P no Ministério do Meio Ambiente. Em 2010, a Lei $n^{\circ} 12.349$ alterou o Art. $3^{\circ}$ Lei $n^{\circ}$ 8.666/1993 (que institui normas para licitações e contratos da Administração Pública) no sentido de incluir a promoção do Desenvolvimento Nacional Sustentável no objetivo das licitações.

Em paralelo, entretanto, o MMA já havia apresentado o projeto de lei que criaria a Política Nacional para Resíduos Sólidos, em cuja Exposição de Motivos no 58/MMA/2007 (em Anexo I) a então Ministra Marina Silva defende, entre outros pontos, que:

A geração de resíduos sólidos é um fenômeno inevitável que ocorre diariamente, ocasionando danos muitas vezes irreversíveis ao meio ambiente. A preocupação com os resíduos é universal e vem sendo discutida há algumas décadas nas esferas nacional e internacional. [...]

A expansão da consciência coletiva com relação ao meio ambiente e a complexidade das atuais demandas ambientais, sociais e econômicas induzem a um novo posicionamento dos três níveis de governo, da sociedade civil e da iniciativa privada em face de tais questões. [...]

A crescente ideia de preservação dos recursos naturais e a questão de saúde pública associada aos resíduos sólidos indicam que a gestão integrada de resíduos sólidos e os processos de tecnologia limpa são caminhos ambientalmente saudáveis, economicamente viáveis e tendem a ser cada vez mais demandados pela sociedade. $[\ldots]$

A primeira Conferência Mundial sobre Ambiente Humano (Estocolmo, 1972) estabeleceu as diretrizes e princípios para a preservação e conservação da natureza e as bases consensuais do desenvolvimento sustentável, que buscam harmonizar o desenvolvimento econômico com a proteção ambiental. [...]

A reunião da Comissão Mundial sobre o Meio Ambiente e Desenvolvimento, realizada em 1982, que resultou no Relatório Bründtland, consolidou uma visão crítica do modelo de desenvolvimento adotado pelos países industrializados e mimetizado pelas nações em desenvolvimento, ressaltando a incompatibilidade 
entre os padrões de produção e consumo vigentes, o uso racional dos recursos naturais e a capacidade de suporte dos ecossistemas. [...]

Percebe-se nessa Exposição de Motivos os princípios que vieram a ser adotados na lei - a preocupação com o tema é universal, as soluções devem passar por governo, sociedade civil e iniciativa privada, a necessidade de uma gestão integrada para preservação dos recursos naturais e saúde pública, a harmonização do desenvolvimento econômico com a proteção ambiental e a incompatibilidade dos padrões de produção e consumo vigentes com o uso racional dos recursos naturais e com a capacidade de suporte dos ecossistemas.

Esse projeto, contudo, em que pese a sua absoluta relevância para a preservação e conservação ambientais, só virou lei em 2010.

\section{4.}

\section{A Política Nacional de Educação Ambiental}

A Lei $n^{\circ}$ 9.795/1999, que dispõe sobre a educação ambiental e institui a Política Nacional de Educação Ambiental (PNEA), começa definindo o que deva ser entendido por Educação Ambiental:

Art. $1^{\circ}$. Entende-se por educação ambiental os processos por meio dos quais o indivíduo e a coletividade constroem valores sociais, conhecimentos, habilidades, atitudes e competências voltadas para a conservação do meio ambiente, bem de uso comum do povo, essencial à sadia qualidade de vida e sua sustentabilidade.

Na sua essência, como se vê, a PNEA concentra-se na construção de valores sociais individuais e, por reflexo, da sociedade como um todo, em torno da qualidade de vida [do povo], que associa à conservação do meio ambiente. $\mathrm{O}$ foco então é a conscientização para a conservação do meio ambiente.

Não é diferente de outros pensadores e organizações.

Por exemplo, em 1975, a UNESCO (Organização das Nações Unidas para a Educação, a Ciência e a Cultura, na sigla em inglês), em congresso promovido em Belgrado, definiu a Educação Ambiental como sendo um processo que visa formar uma população mundial consciente e preocupada com o ambiente e com os problemas que lhe dizem respeito (Seara Filho, 1987).

Em 1996, o renomado geógrafo Aziz Ab’Saber referiu-se à educação ambiental como "o conhecimento da estrutura, da composição e da funcionalidade 
da natureza, das interferências que o homem produziu sobre esta estrutura, esta composição e esta funcionalidade" (1996, p.47).

Mais modernamente, entretanto, registra-se uma evolução desses pensamentos. Por exemplo, diz o Papa Francisco na encíclica 'Laudato si' (2015), primeiro quanto à cultura do desperdício:

\section{CAP. I - O QUE ESTÁ ACONTECENDO EM NOSSA CASA}

Poluição, resíduos e cultura do descarte

21. [...] Produzem-se anualmente centenas de milhões de toneladas de resíduos, muitos deles não biodegradáveis: [...].

22. Estes problemas estão intimamente ligados à cultura do descarte, [...]. Custanos a reconhecer que o funcionamento dos ecossistemas naturais é exemplar: [...]. Ao contrário, o sistema industrial, no final do ciclo de produção e consumo, não desenvolveu a capacidade de absorver e reutilizar resíduos e escórias. Ainda não se conseguiu adotar um modelo circular de produção que assegure recursos para todos e para as gerações futuras e que exige limitar, o mais possível, o uso dos recursos não renováveis, moderando o seu consumo, maximizando a eficiência no seu aproveitamento, reutilizando e reciclando-os. [...].

E depois, sobre a educação ambiental:

2. Educar para a aliança entre a humanidade e o ambiente

210. A educação ambiental vem ampliando os seus objetivos. Se, no começo, estava muito centrada na informação científica e na consciencialização e prevenção dos riscos ambientais, agora tende a incluir uma crítica dos "mitos" da modernidade baseados na razão instrumental (individualismo, progresso ilimitado, concorrência, consumismo, mercado sem regras) [...].

211. Às vezes, porém, esta educação, chamada a criar uma "cidadania ecológica", limita-se a informar e não consegue fazer maturar hábitos. [...]. A educação na responsabilidade ambiental pode incentivar vários comportamentos que têm incidência direta e importante no cuidado do meio ambiente, tais como evitar o uso de plástico e papel, reduzir o consumo de água, diferenciar o lixo, [...].

Algo mudou! Não se trata mais de apenas conscientizar para conservar o ambiente. Fala-se agora da responsabilidade ambiental do cidadão. Fala-se da crítica dos "mitos" da modernidade baseados na razão instrumental. Diz-se que o sistema industrial, no final do ciclo de produção e consumo, não desenvolveu a capacidade de absorver e reutilizar resíduos e escórias. Fala-se do modelo circular de produção, que exige limitar, o mais possível, o uso dos recursos não renováveis.

A PNEA, entretanto, não acompanhou a mudança. Nesse aspecto, a posterior Política Nacional de Resíduos Sólidos (de 2010, adiante analisada) mostra-se muito mais moderna, sintonizada com a evolução do pensamento 
filosófico, científico e político. No Brasil, a inclusão das necessidades sociais tem sido uma constante. Injusto pensar em conservar espécies e ecossistemas ameaçados quando as condições de humanas são indignas. Com base nesse novo pensar, surgiram termos como 'socioambiental', onde o social e o ambiental são tratados de maneira integrada, 'ecodesenvolvimento', 'sustentabilidade”, de autores como Leonardo Boff (Ecologia: Grito da Terra, Grito dos Pobres, 2004), Ignacy Sachs (Caminhos para o Desenvolvimento Sustentável, 2000) e outros.

Não obstante, os mecanismos de execução das ações de educação ambiental estabelecidos pela PNEA permanecem úteis e a execução em si, por meio de projetos e ações, tanto governamentais quanto da sociedade civil, parece estar sintonizada com essa visão. Nessa perspectiva, abre-se espaço para ações ou projetos de educação ambiental versando sobre resíduos sólidos nas organizações em geral. Com isso, empresas conscientes da sua responsabilidade socioambiental corporativa encontram campo para agregar valor aos seus produtos mediante a adoção dos conceitos modernos de economia circular, com propostas de reutilização, reciclagem, compostagem, recuperação ou aproveitamento energético.

\section{5.}

\section{A Política Nacional dos Resíduos Sólidos}

A Lei $n^{\circ}$ 12.305/2010 institui essa Política e dispõe sobre seus princípios, objetivos e instrumentos, bem como sobre as diretrizes relativas à gestão integrada e ao gerenciamento de resíduos sólidos, incluídos os perigosos, às responsabilidades dos geradores e do poder público e aos instrumentos econômicos aplicáveis. A PNRS integra-se à Política Nacional do Meio Ambiente e articula-se com a Política Federal de Saneamento Básico (Lei n $\left.{ }^{\circ} 11.445 / 2007\right)$ e com a Política Nacional de Educação Ambiental (Lei nº 9.795/1999).

Logo no seu início, elenca várias definições, que irão se somar ao glossário “oficial” da Política Nacional de Meio Ambiente (Título I, Capítulo II, Art. $3^{\circ}$ ). Dentre esses termos, têm maior pertinência com o tema desta dissertação os seguintes (grifos do autor): 
Art. $3^{\circ}$

$[\ldots]$

IV - ciclo de vida do produto: série de etapas que envolvem o desenvolvimento do produto, a obtenção de matérias-primas e insumos, o processo produtivo, o consumo e a disposição final;

$[\ldots]$

VII - destinação final ambientalmente adequada: destinação de resíduos que inclui a reutilização, a reciclagem, a compostagem, a recuperação e o aproveitamento energético ou outras destinações admitidas pelos órgãos competentes [...], observando normas operacionais específicas [...];

VIII - disposição final ambientalmente adequada: distribuição ordenada de rejeitos em aterros, observando normas operacionais específicas [...];

IX - geradores de resíduos sólidos: pessoas físicas ou jurídicas, de direito público ou privado, que geram resíduos sólidos por meio de suas atividades, nelas incluído o consumo;

$\mathrm{X}$ - gerenciamento de resíduos sólidos: conjunto de ações exercidas, direta ou indiretamente, nas etapas de coleta, transporte, transbordo, tratamento e destinação final ambientalmente adequada dos resíduos sólidos e disposição final ambientalmente adequada dos rejeitos, [...];

XI - gestão integrada de resíduos sólidos: conjunto de ações voltadas para a busca de soluções para os resíduos sólidos, de forma a considerar as dimensões política, econômica, ambiental, cultural e social, com controle social e sob a premissa do desenvolvimento sustentável;

XII - logística reversa: instrumento de desenvolvimento econômico e social caracterizado por um conjunto de ações, procedimentos e meios destinados a viabilizar a coleta e a restituição dos resíduos sólidos ao setor empresarial, para reaproveitamento, em seu ciclo ou em outros ciclos produtivos, ou outra destinação final ambientalmente adequada;

$[\ldots]$

XIV - reciclagem: processo de transformação dos resíduos sólidos que envolve a alteração de suas propriedades físicas, físico-químicas ou biológicas, com vistas à transformação em insumos ou novos produtos, [...];

$\mathrm{XV}$ - rejeitos: resíduos sólidos que, depois de esgotadas todas as possibilidades de tratamento e recuperação por processos tecnológicos disponíveis e economicamente viáveis, não apresentem outra possibilidade que não a disposição final ambientalmente adequada;

XVI - resíduos sólidos: material, substância, objeto ou bem descartado resultante de atividades humanas em sociedade, a cuja destinação final se procede, se propõe proceder ou se está obrigado a proceder, nos estados sólido ou semissólido, bem como gases contidos em recipientes e líquidos cujas particularidades tornem inviável o seu lançamento na rede pública de esgotos ou em corpos d'água, ou exijam para isso soluções técnica ou economicamente inviáveis em face da melhor tecnologia disponível;

XVII - responsabilidade compartilhada pelo ciclo de vida dos produtos: conjunto de atribuições individualizadas e encadeadas dos fabricantes, importadores, distribuidores e comerciantes, dos consumidores e dos titulares dos serviços públicos de limpeza urbana e de manejo dos resíduos sólidos, para minimizar o volume de resíduos sólidos e rejeitos gerados, bem como para reduzir 
os impactos causados à saúde humana e à qualidade ambiental decorrentes do ciclo de vida dos produtos, [...];

XVIII - reutilização: processo de aproveitamento dos resíduos sólidos sem sua transformação biológica, física ou físico-química, [...];

Da ótica do presente trabalho, destacam-se pela importância:

- o ciclo de vida do produto e

- a responsabilidade compartilhada.

O ciclo de vida do produto como definido na lei está muito bem alinhado com o conceito de "economia circular" preconizado pelo Clube de Roma (Wijkman e Skanberg, 2015), antes citado. Vai desde o desenvolvimento do produto, passa pela obtenção de matérias-primas e insumos e pelo processo produtivo e consumo, e segue até a destinação ou disposição final. Inclui, portanto, a reutilização de resíduos, por meio de logística reversa.

A responsabilidade, pelo seu lado, é compartilhada entre todos os atores fabricantes, importadores, distribuidores e comerciantes, consumidores e serviços públicos de limpeza urbana e de manejo dos resíduos sólidos. A meta comum é minimizar o volume de resíduos sólidos e rejeitos e reduzir os impactos. Isto é, a responsabilidade é de todos, não apenas, por exemplo, do fabricante (que lucra com o produto) ou do serviço público (que é instrumento de socialização do custo da destinação dos resíduos ou rejeitos). Entretanto, a lei é omissa quanto à responsabilidade compartilhada dos atores na "obtenção de matérias-primas e insumos" que constam da definição de ciclo de vida do produto.

Outro verbete que merece comentário é a logística reversa. Parte importante do ciclo de vida do produto, ela é apresentada como um instrumento de desenvolvimento econômico e social. Embora não explicitado na Política, isso se explica possivelmente pela potencialidade de contribuição para a redução de consumo (responsabilidade do consumidor), de custos industriais (responsabilidade do fabricante), de custos para os serviços públicos de limpeza e manejo de resíduos sólidos e de volume de lixo (responsabilidade do governo e da sociedade).

A gestão e o gerenciamento dos resíduos sólidos pautam-se em diretrizes que se alinham com a consciência da finitude dos recursos naturais e da necessidade de encontrar uma solução para todos os resíduos gerados nas atividades humanas, priorizando a não geração de resíduos. Não sendo possível 
fazê-lo, busca-se, sucessivamente, a redução, a reutilização, a compostagem, a reciclagem, o tratamento dos resíduos sólidos e, por fim, a sua disposição final ambientalmente adequada.

O Art. $6^{\circ}$ do Capítulo II, Título II, trata dos Princípios e Objetivos da Política. Alguns desses já foram abordados no Art. $3^{\circ}$ do Capítulo I, Título I, antes discutido. Destacam-se, como temas novos:

Art. $6^{\circ}$

$[\ldots]$

IV - o desenvolvimento sustentável;

V - a ecoeficiência, mediante a compatibilização entre o fornecimento, a preços competitivos, de bens e serviços qualificados que satisfaçam as necessidades humanas e tragam qualidade de vida e a redução do impacto ambiental e do consumo de recursos naturais a um nível, no mínimo, equivalente à capacidade de sustentação estimada do planeta;

$[\ldots]$

VIII - o reconhecimento do resíduo sólido reutilizável e reciclável como um bem econômico e de valor social, gerador de trabalho e renda e promotor de cidadania;

$[\ldots]$

A comentar, a inclusão do Desenvolvimento Sustentável sem que se defina o que deve ser entendido por isso no contexto da lei.

O Art. $7^{\circ}$ seguinte trata dos Objetivos da PNRS. A destacar:

Art. $7^{\circ}$

$[\ldots]$

III - estímulo à adoção de padrões sustentáveis de produção e consumo de bens e serviços;

IV - adoção, desenvolvimento e aprimoramento de tecnologias limpas como forma de minimizar impactos ambientais;

$[\ldots]$

XIII - estímulo à implementação da avaliação do ciclo de vida do produto;

$[\ldots]$

A comentar, primeiro: "III - estímulo à adoção de padrões sustentáveis de produção e consumo de bens e serviços". Seria sustentável, por exemplo, a produção de qualquer bem oriundo de matéria prima não renovável, como o petróleo?

Segundo, "IV - adoção, desenvolvimento e aprimoramento de tecnologias limpas como forma de minimizar impactos ambientais". O que a PNRS consideraria como tecnologia limpa? As que somente utilizam energias de fonte 
renovável, não geram resíduos nem emissões e proporcionam o reaproveitamento total dos resíduos gerados no processo produtivo e no consumo? Sobrariam muito poucas. O objetivo da política, portanto, resta irreal, bastante utópico.

Em suma, de uma maneira geral, esse artigo da PNRS contém imprecisões, que poderiam ser pelo menos em parte sanadas com a 'glossarização' de todos os termos empregados, a exemplo do contido no Art. $3^{\circ}$ antes comentado. A importância disso decorre de se tratar de um texto legal, que poderá ser usado a qualquer tempo para dirimir até mesmo questões judiciais.

Um comentário final sobre o Art. $7^{\circ}-\mathrm{o}$ inciso XIII prevê "estímulo à implementação da avaliação do ciclo de vida do produto". O objetivo geral da presente dissertação, de estabelecer uma metodologia para a metrificação e monetização do ciclo completo de um produto industrial, alinha-se perfeitamente com esse objetivo da Política Nacional de Resíduos Sólidos, uma vez que a metodologia proposta poderá ser sempre uma valiosa ferramenta para avaliação de produtos (nessa linha, como uma contribuição para futuras discussões da avaliação do ciclo de vida de produtos, os termos definidos na legislação estão compilados em um glossário, Anexo II ao presente trabalho).

$\mathrm{Na}$ contramão da gestão compartilhada do ciclo de vida do produto, contudo, há um vácuo na legislação sobre a destinação das embalagens que serão resíduos sólidos uma vez descartadas. O Art. 13, que classifica os resíduos quanto à origem, só permite enquadrar as embalagens no Inciso I, alínea d), como "resíduos de estabelecimentos comerciais e prestadores de serviço". O Art. 14 define responsabilidades sobre a criação de planos de gerenciamento de resíduos, em vários níveis - federal, estadual, microrregional, intermunicipal, municipal - e, por suposto, o das empresas produtoras ou distribuidoras das embalagens. Estas, entretanto, são desobrigadas de terem planos de gerenciamento para (e, decorrentemente, responsabilidades sobre) as embalagens descartáveis. Na falta de alternativa explícita, tais embalagens passam a ser "resíduos sólidos urbanos", como parte dos resíduos domiciliares e dos decorrentes de varrição e limpeza de vias públicas. Não resta, portanto, responsabilidade nem incentivo para o reaproveitamento, em qualquer de suas formas. Resultado: embalagens plásticas, garrafas de PET e vários outros tipos de embalagens simplesmente vão para as ruas, os rios, os mares, as praias, e passam a ser de responsabilidade do Poder Público, não mais do produtor, nem do consumidor. Em consequência, numa 
abordagem superficial, a destinação final dessa categoria de resíduo - as embalagens descartáveis - não estaria incluída no ciclo de vida do produto, que se encerraria no momento em que o produto sai da fábrica.

Ainda sobre Responsabilidade Compartilhada, vale examinar também o Art. 30 do Título III, Capítulo III, Seção II. Estão nele incluídos fabricantes, importadores, distribuidores, comerciantes, consumidores e os titulares dos serviços públicos de limpeza urbana e de manejo de resíduos sólidos (mais uma vez, ficam de fora os fornecedores de matéria prima e insumos). Diz o parágrafo único da lei:

\section{Art. 30}

$[\ldots]$

Parágrafo único. A responsabilidade compartilhada pelo ciclo de vida dos produtos tem por objetivo:

$[\ldots]$

II - promover o aproveitamento de resíduos sólidos, direcionando-os para a sua cadeia produtiva ou para outras cadeias produtivas;

III - reduzir a geração de resíduos sólidos, o desperdício de materiais, a poluição e os danos ambientais;

IV - incentivar a utilização de insumos de menor agressividade ao meio ambiente e de maior sustentabilidade;

$[\ldots]$

Por esses objetivos, depreende-se inicialmente que compete ao produtor (II) direcionar os resíduos para alguma cadeia produtiva. Confirma-se então que o ciclo do produto não se encerra no momento em que o produto é entregue para o consumo. Na modelagem do ciclo, portanto, os custos posteriores, de destinação final do produto, devem ser incluídos.

O inciso III - reduzir a geração de resíduos sólidos, o desperdício de materiais, a poluição e os danos ambientais - remete também às etapas do ciclo do produto posteriores à distribuição de um produto para consumo.

E o inciso IV - incentivar a utilização de insumos de menor agressividade ao meio ambiente e de maior sustentabilidade - finalmente insere a matéria prima no contexto, já não era sem tempo! Acrescenta-se, portanto, à metodologia de modelar a questão de como metrificar e monetizar também as matérias primas e os insumos. 
O Art. 31 seguinte, que trata do fortalecimento da responsabilidade compartilhada e seus objetivos, estende essa responsabilidade a fabricantes, importadores, distribuidores e comerciantes: (III) "o recolhimento dos produtos e dos resíduos remanescentes após o uso, assim como sua subsequente destinação final ambientalmente adequada, no caso de produtos objeto de sistema de logística reversa [...]”. Mais uma vez, os custos decorrentes da logística reversa também devem ser considerados na metrificação e monetização do ciclo de vida dos produtos.

Os Art. 32 e 33 abordam o tema das embalagens e logística reversa. Do primeiro, vê-se que:

Art. 32. As embalagens devem ser fabricadas com materiais que propiciem a reutilização ou a reciclagem.

$\S 1^{\circ}$ Cabe aos respectivos responsáveis assegurar que as embalagens sejam:

$[\ldots]$

I - projetadas de forma a serem reutilizadas [...];

III - recicladas, se a reutilização não for possível.

$\S 3^{\circ}$ É responsável pelo atendimento do disposto neste artigo todo aquele que:

I - manufatura embalagens ou fornece materiais para a fabricação de embalagens;

II - coloca em circulação embalagens, materiais para a fabricação de embalagens ou produtos embalados, em qualquer fase da cadeia de comércio.

Resta cristalino então que, segundo a lei, contrariamente a práticas comumente exercitadas no país, a responsabilidade (e os custos!) pela destinação final de embalagens descartáveis não deveria ser arcada pelo poder público, na forma de recolha de lixo e deposição em aterros sanitários (apropriação dos lucros pelo produtor, socialização dos prejuízos com a sociedade). Logo, ainda mais uma vez, a modelagem do ciclo de vida do produto, embalagens, no caso, deve incluir essa etapa, mesmo nos casos em que esse custo esteja sendo 'socializado' pelo poder público com a população.

O Art. 33 confirma esse entendimento:

Art. 33 - São obrigados a estruturar e implementar sistemas de logística reversa, mediante retorno dos produtos após o uso pelo consumidor, de forma independente do serviço público de limpeza urbana e de manejo dos resíduos sólidos, os fabricantes, importadores, distribuidores e comerciantes de:

$[\ldots]$

Contraditoriamente, contudo, a lei não considera as embalagens em geral, o que é estranho face ao enorme volume de embalagens descartado. Embalagens de 
alimentos, refrigerantes e similares, de plástico ou PET, por exemplo, ficam fora da lista, que se resume a agrotóxicos, pilhas e baterias, óleos lubrificantes, lâmpadas e produtos eletroeletrônicos.

Os artigos finais da PNRS versam sobre vários outros pontos relevantes (resíduos perigosos, instrumentos econômicos, proibições), mas sem pertinência com a modelagem do ciclo de vida dos produtos, pelo não são aqui tratados.

Em síntese, em que pesem eventuais críticas ou sugestões de aprimoramento que se possa aduzir, o arcabouço legal existente bem demonstra a conscientização do poder público brasileiro para a problemática das mudanças climáticas, das ameaças de degradação ambiental e das teses de desenvolvimento e consumo crescentes e permanentes baseados em recursos naturais finitos. Em verdade, o conjunto de leis mostra uma visão bastante moderna. 


\title{
3 \\ Elementos externos que influenciam o ciclo de vida
}

\section{1. \\ As embalagens}

Antes de examinar os elementos externos que de uma forma ou de outra influenciam as etapas do ciclo de vida das embalagens descartáveis, convém elaborar sobre as embalagens em si, diante da relevância que têm na vida moderna.

Iniciando pela conceituação, vê-se que as definições do que seja embalagem, por parte de várias entidades representativas, órgãos setoriais e autores, convergem. Algumas delas:

\begin{abstract}
Embalagem é um recipiente ou envoltura que armazena produtos temporariamente, individualmente ou agrupando unidades, tendo como principal função protegê-los e estender o seu prazo de vida (shelf life), viabilizando sua distribuição, identificação e consumo (ABRE - Associação Brasileira de Embalagens).

Embalagem é o recipiente destinado a garantir a conservação, transporte e manuseio dos alimentos (ANVISA - Agência de Vigilância Sanitária, 2010).

Embalagem é qualquer forma pela qual o alimento tenha sido acondicionado, guardado ou envasado (Decreto-Lei 986/1969 - Institui normas básicas sobre alimentos).
\end{abstract}

No setor de alimentos, as embalagens são hoje indispensáveis para atender as necessidades de alimentação, saúde e conveniência. Disponibilizam produtos com segurança, servem de veículo de informações, possibilitam acesso a produtos frágeis ou perecíveis, de alto ou baixo valor agregado, propiciam novas formas de preparo de alimentos, com o uso dos eletrodomésticos. No mercado altamente competitivo dos dias atuais, são estratégicas para a competitividade dos negócios no que diz respeito à eficiência da distribuição e da venda de produtos. Frente ao crescimento populacional do planeta, são essenciais para o aproveitamento dos alimentos e insumos demandados pela sociedade e para a redução do desperdício.

As embalagens em geral servem como parâmetro para medir o nível de atividade econômica de cada país e contribuem para que mais pessoas tenham 
acesso aos produtos. Segundo a ABRE (Associação Brasileira de Embalagens), movimentam mundialmente mais de US $\$ 500$ bilhões, representando entre $1 \%$ e 2,5\% do PIB de cada país. No Brasil, movimentam atualmente R 47 bilhões e geram mais de 200 mil postos de emprego diretos e formais (www.abre.org.br).

Têm também expressão no impacto ambiental da produção de alimentos. Segundo Kooijman (1995), em média 49\% da pegada ambiental de um alimento referem-se ao seu plantio, cultivo, colheita e/ou processamento; $11 \%$ à distribuição; $16 \%$ ao resfriamento para conservação; $14 \%$ ao preparo e $10 \%$ à embalagem. Deste percentual, a embalagem primária participa com $7 \%$ e a de transporte com 3\%. No conjunto dos fatores que concorrem para o impacto ambiental das residências em geral, aquele autor lista como médias, nas residências nos EUA:

A embalagem, enfim, é um utensílio de acondicionamento em forma de recipiente ou envoltório. Em geral, emprega como matéria-prima vidro, metal, celulose, plástico ou biopolímeros (bioplásticos) de fonte renovável. Sua consistência varia desde as rígidas (vidro, metal) até as mais flexíveis (plásticos, celofane, papel, alumínio).

A classificação das embalagens biodegradáveis e compostáveis segue as normas ABNT NBR 15448-1 (Terminologia) e NBR 15448-2 (Biodegradação e Compostagem) "Embalagens Plásticas Degradáveis e/ou Renováveis". Essas normas classificam as embalagens em três tipos:

a) Primárias - aquelas que ficam em contato direto com o alimento.

b) Secundárias - as de distribuição, que protegem as embalagens primárias.

c) Terciárias - as de transporte, empregadas para acondicionar e proteger as embalagens primárias e secundárias durante o transporte, estocagem e distribuição.

Segundo a destinação que se lhes dê após a primeira utilização, podem ser:

a) Descartáveis - a serem descartadas após a primeira utilização. De estrutura mais simples, usam menos matéria-prima e o seu processamento consome menos energia.

b) Retornáveis - a serem retornadas ao processo de fabricação, para reenvasamento, após lavagem e esterilização, seguindo etapas de transporte da logística reversa. 
c) Reutilizáveis - a serem reaproveitadas pelo consumidor para o acondicionamento de outros produtos, uma vez devidamente ajustadas para que não prejudiquem a saúde e a segurança do consumidor.

As embalagens podem ainda ser produzidas considerando as seguintes opções de destinação ou disposição final:

a) Recicláveis - aquelas cuja matéria-prima pode ser reaproveitada, para finalidades diversas, após transformações químicas e/ou físicas.

b) Biodegradáveis - aquelas que, degradadas por microrganismos, desfazem-se, liberando $\mathrm{CO}_{2}$ para atmosfera, sob determinadas condições de calor, umidade e oxigênio.

c) Compostáveis - tipo específico de embalagens biodegradáveis que podem ser destinadas à compostagem orgânica.

d) Não biodegradáveis - aquelas que não se degradam naturalmente ou que o fazem após um prazo superior a 10 anos (segundo norma do Comitê Organizador dos Jogos Olímpicos do Rio de Janeiro).

Notas:

O descarte descuidado de uma embalagem pode comprometer a sua reciclagem ou biodegradação, tornando-a tão nociva quanto as embalagens não biodegradáveis.

Plásticos levam de 10 a 400 anos para se degradar; metais, de 50 a 200 anos; vidros têm duração indeterminada.

As embalagens de que trata este estudo são os copos, que se enquadram na classificação da seguinte forma:

a) Copo de plástico - descartável, de matéria-prima fóssil, não biodegradável, com disposição final em aterros.

b) Copo de mandioca - descartável, de matéria-prima de fonte renovável, biodegradável, compostável.

\section{2.}

\section{Os resíduos sólidos e sua destinação}

Em 2008, o Brasil tinha 5.564 municípios (hoje são 5.570). Desses, 97,8\% contavam com serviço de manejo de resíduos sólidos, com coleta regular nas vias públicas, mas apenas 994 (18\%) faziam coleta seletiva para fins de reciclagem (IBGE - Pesquisa Nacional de Saneamento Básico, 2008). 
Em termos nacionais, são coletados $98,5 \%$ dos resíduos urbanos, um volume diário de 183.485 toneladas. Desse total, 43\% são coletados nos municípios pequenos (menos que 50.000 habitantes), 34\% nos médios (entre 100 mil e 1 milhão de habitantes) e de 22,5\% nos grandes municípios. A tendência verificada é de aumento da quantidade dos resíduos nos municípios pequenos e médios, com redução nos municípios grandes. Na média nacional, são 1,1 kg/habitante/dia de resíduos sólidos (IBGE, 2002, 2010a). Do total de municípios brasileiros, somente 16,8\% (936) fazem tratamento dos resíduos sólidos e a coleta seletiva é feita em apenas $355,38 \%$ deles.

O panorama da situação dos resíduos sólidos urbanos compilado pela ABRELPE (Associação Brasileira de Empresas de Limpeza Pública e Resíduos Especiais) é o seguinte:

Tabela 1 - Panorama dos Resíduos Sólidos Urbanos (RSU) - 2012

\begin{tabular}{cccccc}
\hline Região & $\begin{array}{c}\text { Participação } \\
\text { das regióes no } \\
\text { total de RSU } \\
\text { coletado }\end{array}$ & $\begin{array}{c}\text { Índice de } \\
\text { abrangência de } \\
\text { coleta de RSU }\end{array}$ & $\begin{array}{c}\text { \% com } \\
\text { coleta } \\
\text { seletiva de } \\
\text { RSU }\end{array}$ & $\begin{array}{c}\text { T/dia de } \\
\text { RSU gerado }\end{array}$ & $\begin{array}{c}\text { T/dia de } \\
\text { RSU } \\
\text { coletado }\end{array}$ \\
\hline Norte & $6,4 \%$ & $84,23 \%$ & $47,4 \%$ & 13.574 & 11.585 \\
Nordeste & $22.1 \%$ & $77,43 \%$ & $37,8 \%$ & 51.689 & 40.021 \\
C. Oeste & $8,1 \%$ & $92,11 \%$ & $31,8 \%$ & 16.055 & 14.788 \\
Sudeste & $52,5 \%$ & $96,87 \%$ & $80,5 \%$ & 98.215 & 95.142 \\
Sul & $10,9 \%$ & $92,54 \%$ & $79.5 \%$ & 21.345 & 19.752 \\
Brasil & & $90,17 \%$ & $58,8 \%$ & 201.058 & 181.288 \\
\hline
\end{tabular}

(Fonte: ABRELPE)

Ainda segundo a ABRELPE, do total coletado, os resíduos orgânicos representam 52,4\% (29.072.794 t/ano) e o plástico representa 13,5\% (7.635.851 t/ano).

As unidades de destinação final dos resíduos sólidos são os aterros controlados, os aterros sanitários, as unidades de compostagem, as unidades de tratamento por incineração, as unidades de triagem para reciclagem, os vazadouros a céu aberto, os vazadouros em áreas alagáveis, locais não fixos e outras unidades de destinação. 
Tabela 2 - Destinação final em volume diário de resíduos sólidos

\begin{tabular}{lc}
\hline \multicolumn{1}{c}{ Unidades de destinação } & T/dia \\
\hline \hline Aterro controlado & 33.854 \\
Aterro sanitário & 64.164 \\
Estação de compostagem & 6.535 \\
Estação de triagem & 2.250 \\
Incineração & 511 \\
Locais não fixos & 878 \\
Outras unidades & 1.018 \\
Vazadouro & 47.392 \\
Áreas alagadas & 237 \\
Total (t/dia) & 157.708 \\
\hline
\end{tabular}

(Fonte: ABRELPE)

O que se percebe desse panorama é que os pouco mais de $40 \%$ dos resíduos sólidos urbanos que contam com destino inadequado - cerca de 24 milhões de toneladas - distribuem-se por mais de 3.000 municípios, a maioria deles com menos de 10.000 habitantes e ainda sem condições técnicas e financeiras de se adequarem às políticas. $\mathrm{O}$ que vem se registrando em realidade é um aumento constante na geração de resíduos, aumento possivelmente maior do que o próprio crescimento populacional. Daí decorre importância crescente das soluções que contribuam para uma meta de lixo zero na produção de bens e serviços.

\section{4 . \\ Polímeros, biodegradação e compostagem}

A degradação é um fenômeno físico-químico que depende de um elemento gerador, o qual irá definir a sua classificação. Se o elemento gerador for de fonte biológica - fungos, bactérias - haverá biodegradação; de fonte de calor, será termodegradação; se for um óxido, será oxidegradação, etc.

Antes, porém, de se tratar das modalidades de degradação, importa esclarecer previamente o que são um polímero e um biopolímero.

Polímero deriva do grego poli (muitos) + meros (iguais). São macromoléculas formadas pela repetição de muitas unidades químicas iguais, os meros ou unidades repetitivas. Os biopolímeros são polímeros naturais, e as suas propriedades podem ser alteradas por diferentes métodos físicos e químicos. Isso permite a seleção de propriedades importantes, como capacidade de absorção de água, cinética de degradação ou propriedades mecânicas adequadas a 
determinadas aplicações. Da sua decomposição resultam subprodutos naturais, como gases $\left(\mathrm{CO}_{2}, \mathrm{~N}_{2}\right)$, água, biomassa e sais inorgânicos.

As fontes mais usuais de matéria-prima dos biopolímeros são: (i) plantas e algas, representadas por fécula de mandioca, amidos (amilose, amilopectina) de milho, cana e/ou celulose, pectina, ginato carraginato, gomas, soja, glúten de trigo, caseína, soro de albumina, sedas, elastina, polihidroxialcanoatos; (ii) bactérias (quitina, quitosana, xantano, poligalactosamina, gelano, dextrano); (iii) animais (ácido hialurônico, quitina, quitosana).

A biodegradação é a destruição ou mineralização de matéria orgânica por microrganismos existentes no solo, ar ou água. Todos os elementos naturais são por princípio biodegradáveis - se desfazem, apodrecem e se tornam parte da terra novamente, sem deixar qualquer resíduo. Logo, um produto é biodegradável quando simplesmente se desfaz ou apodrece, de maneira fácil e natural, e se torna parte da terra novamente, sem deixar qualquer resíduo (para fins práticos, como antes apontado, há um limite temporal para se considerar um elemento como biodegradável, como os 10 anos preconizados pela autoridade olímpica no Brasil).

A compostagem é um processo de biodegradação. O termo está associado à manipulação de material orgânico de acordo com técnicas para acelerar a decomposição e produzir um elemento útil, o composto orgânico. Obtido no processo de compostagem, o composto, estabilizado e higienizado, é rico em húmus e em nutrientes minerais. Seu grande benefício é o aproveitamento agrícola para reposição dos nutrientes do solo. É uma alternativa ambientalmente correta para a destinação final da porção orgânica dos resíduos sólidos, pois evita que seja destinada a aterros sanitários e ainda agrega valor à agricultura, reflorestamento ou jardinagem. Além disso, o produto da compostagem, a terra vegetal, tem um valor comercial.

No processamento dos resíduos, muitos custos poderiam ser cortados caso a matéria orgânica fosse separada na fonte e encaminhada para compostagem.

Segundo dados de uma associação empresarial dedicada a promoção da reciclagem - CEMPRE (www.cempre.org.br) publicado em 2002 com o título “ compromisso empresarial para a reciclagem", cerca de $5 \%$, do lixo sólido orgânico urbano gerado no Brasil foi reciclado. ("compostado"). Em termos absolutos tem-se 211 municípios brasileiros com unidades de compostagem, 
sendo que os Estados de Minas Gerais e Rio Grande do Sul possuem a maior concentração, 78 e 66 unidades respectivamente. -

Não é muito animador, mas esse panorama pode melhorar, à medida que a legislação for sendo aplicada, em particular quanto à Lei no 11.445/2007 (Política Nacional de Saneamento Básico) e à Lei no 12.305/2010 (Política Nacional de Resíduos Sólidos). Na Europa, por exemplo, desde que a Diretiva Europeia EU 1999/31 exigiu a redução significativa do aterramento de resíduos orgânicos, a compostagem se tornou uma alternativa concreta (Altinbas et al., 2007, apud IPEA, 2010).

Fácil, portanto, perceber que produtos compostáveis agregam valor à cadeia do produto. Primeiro, têm origem em matéria-prima renovável. Se devidamente destinados, transformam-se em um novo produto (o composto orgânico) e não deixam resíduos (lixo zero). Se não destinados à compostagem, naturalmente se degradam, mais uma vez gerando zero lixo.

\section{5. \\ Logística reversa e responsabilidade estendida ao produto}

Uma definição de logística reversa que reúne a opinião de vários autores é bem resumida por Paulo Roberto Leite em artigo publicado na Revista Tecnologística (LEITE, Paulo Roberto. Logística Reversa - Nova área da logística empresarial. São Paulo: Editora Publicare, maio 2002):

Área da Logística Empresarial que planeja, opera e controla o fluxo, e as informações logísticas correspondentes, do retorno dos bens de pós-venda e de pósconsumo ao ciclo de negócios ou ao ciclo produtivo, através dos Canais de Distribuição Reversos, agregando-lhes valor de diversas naturezas: econômico, ecológico, legal, logístico, de imagem corporativa, entre outros.

A logística reversa no pós-consumo equaciona e operacionaliza o fluxo físico dos bens descartados, que, em geral, retornam ao ciclo de negócios ou ao ciclo produtivo (economia circular) por meio de canais de distribuição reversos. Esses produtos de pós-consumo podem se originar de bens duráveis ou descartáveis e fluir por canais reversos de reuso, desmanche, reciclagem ou compostagem, em sua destinação final.

A Politica Nacional de Resíduos Sólidos (PNRS), como antes visto, diz:

A logística reversa é um instrumento de desenvolvimento econômico e social, caracterizado por um conjunto de ações, procedimentos e meios destinados a 
viabilizar a coleta e a restituição dos resíduos sólidos ao setor empresarial, para reaproveitamento - em seu ciclo ou em outros ciclos produtivos - ou para outra destinação final ambientalmente adequada.

Já o termo "Extended Producer Responsibility" - EPR, ou Responsabilidade Estendida ao Produto, foi cunhado em 1990 pelo Dr. Thomas Lindhqvist, titular do "International Institute for Industrial Environmental Economics" (IIIEE). O conceito é definido como uma estratégia de reduzir o impacto ambiental total de um produto para proteção do meio ambiente. Faz do fabricante responsável por todo o ciclo de vida do produto e, especialmente, pela sua destinação final. Pode ser entendido como um princípio de política de produto, que transfere aos fabricantes uma maior responsabilidade pelo seu produto.

No contexto desta dissertação, a EPR tem grande relevância - a de reafirmar a inclusão dos custos realizados em etapas posteriores à comercialização do item, relativos à destinação final do produto, no ciclo de vida do produto.

\section{6. \\ Custo ambiental}

O conceito de custo ambiental é definido por Regatschnig e Schnitzer (1998) como sendo:

Os custos que podem aparecer como o resultado das atividades ambientais da empresa, ou seja, atividades estabelecidas em lei ou voluntárias, que visam evitar, reduzir, tratar ou dispor os seus rejeitos e emissões, mas que podem ser resultantes da falta de políticas ambientais na organização.

Eagan e Joeres (2002) definem custo ambiental como sendo os custos incorridos pela empresa devido aos impactos ambientais resultantes da manufatura de seus produtos. Na mesma linha, Jasch (2003) entende que o custo ambiental compreende os custos internos e externos que surgem devido a danos ao meio ambiente ou à sua proteção. Por fim, Hansen e Mowen (2001) definem custo ambiental como os custos incorridos porque existe, ou pode existir, uma má qualidade ambiental.

O grande defensor do uso do custo ambiental na matriz de preços de venda dos produtos, para tornar mais competitivo um produto classificado como ambientalmente correto, foi Herman Daly, considerado o pai da economia ecológica (ECOECO, 2008). Ele foi um dos primeiros economistas 
contemporâneos a defender que os custos ambientais deveriam estar refletidos nos preços de venda dos serviços e mercadorias. Acompanhando as propostas de Daly, custo ambiental é o custo dos impactos ao longo do ciclo de vida do produto sobre o meio ambiente.

No modelo de monetização deste estudo, são considerados os impactos positivos e negativos associados o ciclo de vida do produto:

a) Emissões de dióxido de carbono desde a busca da matéria-prima até a produção;

b) Volume de água utilizado no processo industrial;

c) Área utilizada em aterro sanitário no descarte;

d) Volume de terra vegetal gerada na compostagem;

e) Volume de biogás gerado nos biodigestores. 


\section{4}

\section{Modelagem do ciclo de vida dos copos descartáveis}

\section{1.}

\section{Etapas e elementos do ciclo de vida}

A Fig. 5 abaixo ilustra as etapas do ciclo de vida das embalagens descartáveis de mandioca e os elementos que entram na sua composição. É o conceito "da terra a terra".

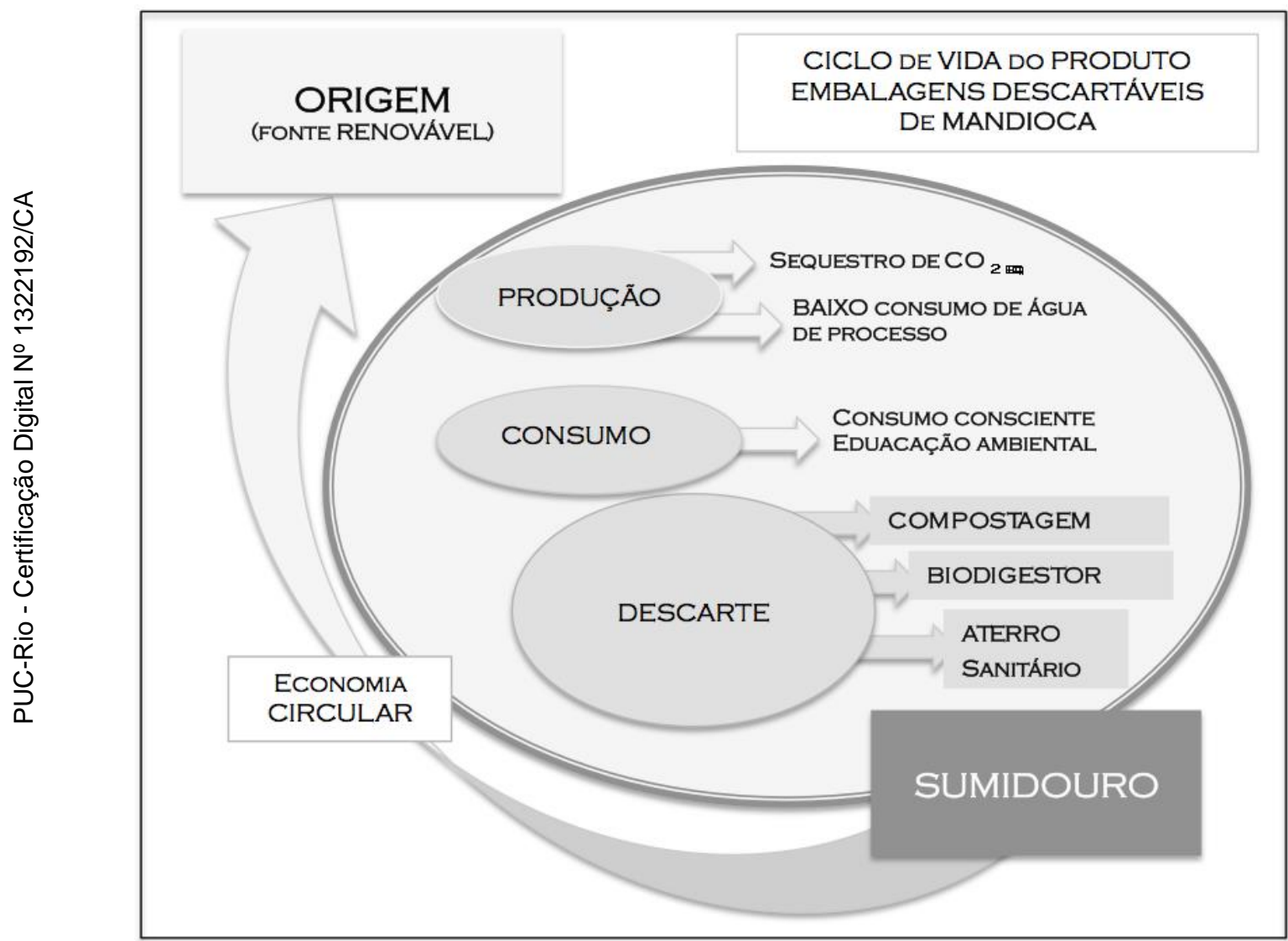

Figura 5 - etapas do ciclo de vida dos copos descartáveis de mandioca

A Fig. 6 abaixo ilustra as etapas do ciclo de vida das embalagens descartáveis de plástico e seus respectivos elementos. Ao se mencionar o desperdício, significa o mal uso do produto "copos plásticos" quer na retirada do mesmo dos distribuidores de copos, que na maioria saem mais de um copo e 
também o uso de mais de um copo para dar uma maior rigidez ao copo ou proteção no caso de uso de líquidos quentes.

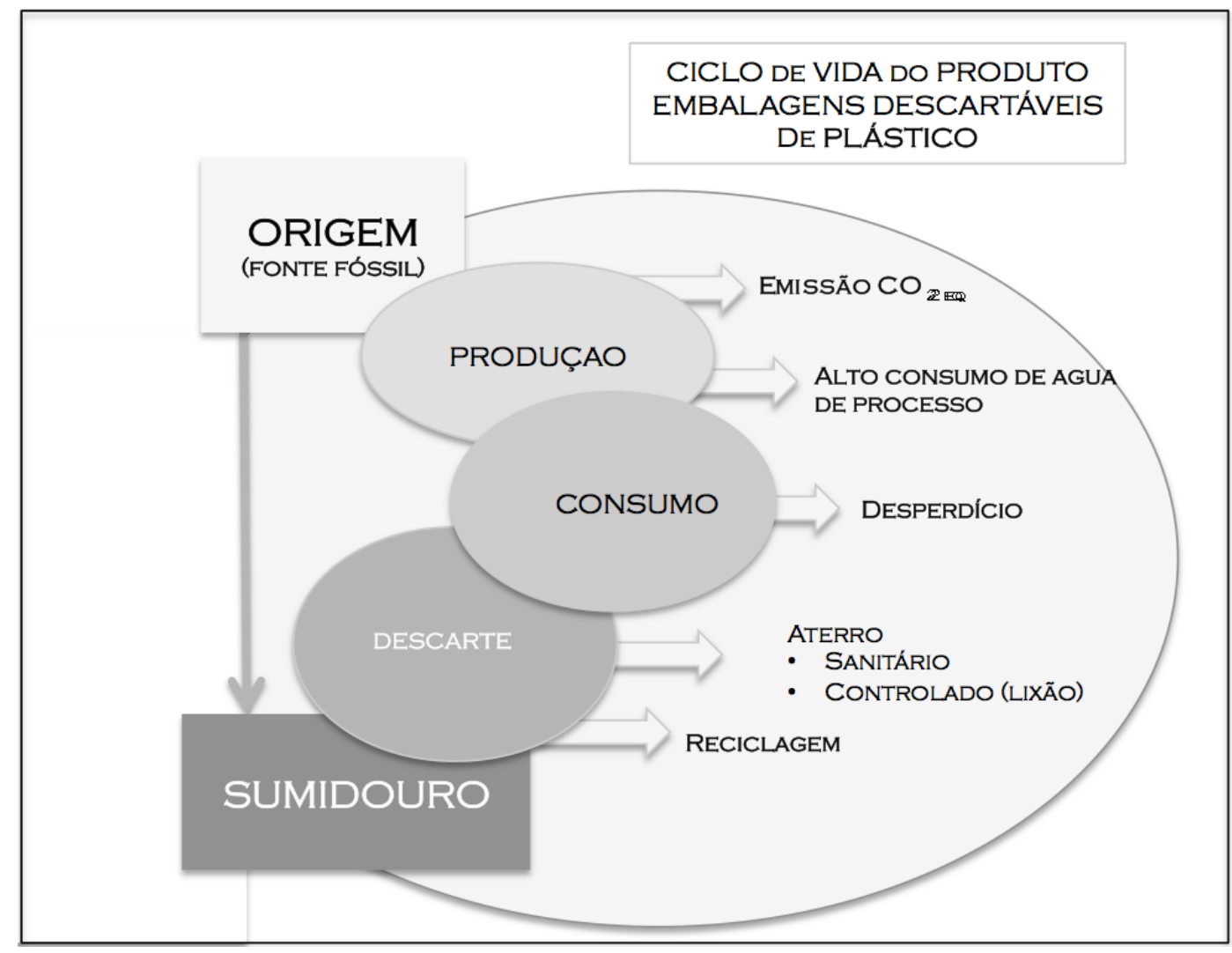

Figura 6 - etapas do ciclo de vida dos copos descartáveis de plástico

Restritos aqui aos copos descartáveis, serão inicialmente descritas as matérias-primas que entram em jogo e informações sobre elas, após o que serão diretamente tratadas a modelagem dos processos de metrificação e de monetização.

\section{2.}

\section{As matérias-primas}

Mandioca e plástico são os materiais utilizados para a fabricação dos copos descartáveis em exame. Cada um deles têm suas características e funcionalidades, como a seguir detalhado. 


\subsection{1. Mandioca}

São dois os tipos de mandioca. O primeiro é destinado à fabricação de ração alimentar, em forma de farinha. Esse processo é realizado por grandes e médios empreendimentos ou de forma artesanal por mais de 900 mil agricultores familiares (SEBRAE - XV Congresso Brasileiro de Mandioca - Salvador, BA, 2013). O segundo, denominado mandioca braba, é destinado à indústria. A transformação da mandioca in natura em fécula dá-se em uma usina conhecida como fecularia. A fécula é utilizada pelas indústrias têxteis, de papel, de alimentos, de petróleo (carga de lubrificação de brocas de perfuração). O Brasil é o segundo maior produtor mundial do tubérculo, sendo superado apenas pela Indonésia. As fecularias no Brasil estão localizadas nas principais regiões industriais, com destaque para o oeste de São Paulo e o norte do Paraná.

A descrição e a definição de féculas e amidos são dadas por normas técnicas baixadas pela Resolução $\mathrm{n}^{\circ} 12$ da Comissão Nacional de Normas e Padrões para Alimentos - CNNPA (Diário Oficial da União, de 24/07/1978 www.anvisa.gov.br/anvisalegis). Segundo essa norma:

- Fécula é o produto amiláceo extraído das partes subterrâneas comestíveis dos vegetais (tubérculos, raízes e rizomas);

- Amido é o produto amiláceo extraído das partes aéreas comestíveis dos vegetais (sementes), etc.

Ainda segundo a norma, o produto é designado "fécula" ou "amido", seguido do nome do vegetal de origem. Ex.: "fécula de mandioca", "amido de milho", "fécula de batata".

\subsection{2.}

\section{Plástico}

São materiais orgânicos poliméricos sintéticos, de constituição macromolecular, cuja matéria-prima é geralmente o petróleo. Servem de matériaprima básica para a fabricação dos mais variados objetos. A fração nafta do petróleo produzida nas refinarias é fornecida para as centrais químicas e petroquímicas, onde passa por uma série de processos, dando origem aos 
principais monômeros, como o poliestireno, a partir do qual o copo de plástico é produzido.

\subsection{3.}

\section{Fontes de dados}

\section{I) Copos de mandioca - a CBPAK Tecnologia S/A}

Todos os dados referentes à mandioca e sua aplicação na fabricação de copos compostáveis são originários da empresa CBPAK Tecnologia S/A (www.cbpak.com.br) e de outras organizações a ela ligadas, em particular a fecularia Bahiamido Serviços Agroindustriais S/A (bahiamido.com.br) e a empresa Green Domus Desenvolvimento Sustentável Ltda. (www.greendomus.com.br). Esta última realizou, para a CBPAK, o estudo "Inventári o de emissões de gases de efeito estufa 2013 da cadeia de produção dos copos descartáveis de mandioca fabricados pela CBPAK Tecnologia S/A Embalagens Ecossustentáveis” (v. 06, 2014), cujos dados foram utilizados na presente dissertação.

A CBPAK é uma empresa de tecnologia genuinamente brasileira, focada na pesquisa, desenvolvimento, industrialização e comercialização de embalagens descartáveis produzidas a partir de matéria-prima de fonte renovável, a fécula da mandioca. Essas embalagens - copos, bandejas para alimentos, tubetes para mudas de plantas -, biodegradáveis, compostáveis, térmicas e rígidas, são o meio físico para se implantar soluções ambientais de emissão de baixo carbono em empresas clientes.

Fundada em 2002, é pioneira no uso de biopolímeros para a fabricação de embalagens. Tem como diferenciais de negócio um núcleo de $\mathrm{P} \& \mathrm{D}$ próprio, a cooperação regular com instituições de pesquisa (Instituto de Pesquisas Energéticas e Nucleares - IPEN/SP, Instituto de Química da UFRJ) e a inovação continuada. Graças a essa postura de inovação - de produto, processo, modelo de negócios e organização -, tem conquistado seguidas premiações: Prêmio Finep de Inovação Sustentável 2013, $2^{\circ}$ lugar no concurso CNI/ SEBRAE/ FINEP/ MBC/ MCTI de Inovação em Modelo de Negócio 2014, finalista do programa de internacionalização "Inovação na Criação de Valor". 
A linha do tempo da CBPAK registra:

2002 - desenvolvimento do uso da mandioca para fabricação de embalagens térmicas, rígidas e compostáveis, por termoexpansão; estruturação de setor de $\mathrm{P} \& \mathrm{D}$ próprio, com fomento FINEP; colaboração com o IPEN-SP.

2003 - desenvolvimento de técnica para impermeabilização dos produtos.

2004 - projeto e construção da primeira máquina automática de produção; desenvolvimento de prensas pneumáticas interligadas para fechamento de moldes, em substituição aos processos tradicionais utilizados na produção de peças plásticas.

2006 - três pedidos de patente no INPI.

2011 - projeto e construção de máquinas automáticas de múltiplas estações, com o uso de automação industrial e robótica.

2012 - concepção de novo processo de aplicação do material impermeabilizante no sistema produtivo.

2013 - concepção e aplicação de modelo de negócios para oferecer a empresas de grande porte programas ambientais para fortalecimento da imagem corporativa, mediante uso de embalagens compostáveis e de reeducação para a sustentabilidade.

2014/2015 - desenvolvimento de método para impermeabilização das embalagens ao longo do processo de fabricação; "tubetes inteligentes" para plantação de mudas em campanhas de reflorestamento em grande escala; uso de novos materiais por modificações químicas e físicas da fécula e do farelo da casca da mandioca; substituição da termoexpansão por injeção líquida da matéria prima; nova unidade organizacional para controle metrológico operacional e integração dos dados das áreas industrial, comercial e administrativa. Projeto de internacionalização com a APEX/FGV.

Na dimensão da sustentabilidade ambiental, a proposta da CBPAK é permitir que a embalagem descartada possa, em seu destino final, ser endereçada a um centro de compostagem, para transformação em terra vegetal, retornando assim ao ciclo produtivo, segundo o conceito de economia circular.

A invenção das embalagens compostáveis inspirou-se na própria natureza. As cascas das frutas, por exemplo, são embalagens naturais, que, após proteger o fruto, são descartadas, e, independentemente de sua destinação final, degradam-se de forma natural, no conceito mais puro da compostabilidade, ou seja, "da terra à terra". Assim é com as embalagens de fécula de mandioca da CBPAK: depois de utilizadas, vão para os centros de compostagem, onde, misturadas a outros resíduos orgânicos, torna-se terra vegetal por compostagem aeróbica.

A CBPAK agrega à sua gênese e trajetória um conjunto de fatores: (i) uma descoberta - a fécula de mandioca como matéria-prima; (ii) um desafio transformar essa descoberta em produto industrial; (iii) um interesse - tornar esse desafio uma efetiva realidade empresarial; (iv) uma crença - de que é possível, 
importante e necessário desenvolver produtos ecossustentáveis; (v) uma perseverança - desbravar e conquistar um mercado consumidor para esses produtos. Dentre seus valores, a CBPAK crê na força da emergente economia dita verde e sustentável. Romper com conceitos clássicos ultrapassados e exercitar o empreendedorismo e a inovação comprometidos e norteados por importantes valores, como o desenvolvimento sustentável, a integração social e a conservação do meio ambiente, representa um importante desafio para a empresa.

O modelo de negócio desenvolvido pela empresa está em sintonia com a realidade de introduzir e sustentar um discurso de que os produtos CBPAK, totalmente compostáveis, são parte de uma solução ambiental, e não uma apenas uma commodity. Isto significa ver o mercado sob outro ângulo e de modificar a sua percepção e lógica de compra. No fundo, um exercício de mudança de paradigma, ou seja, entrega-se VALOR, e não somente PREÇO. As embalagens compostáveis de mandioca estão totalmente enquadradas e alinhadas com as tendências mundiais de mitigação do uso de embalagens poluentes, com destinação final descontrolada e geração de grande volume de rejeitos.

$\mathrm{O}$ processo industrial da CBPAK se enquadra nos modernos preceitos de baixos impactos ambientais e emissões. Da fécula de mandioca, tendo a água como solvente, produz-se uma massa que, colocada em um molde aquecido, transforma-se no produto final. 


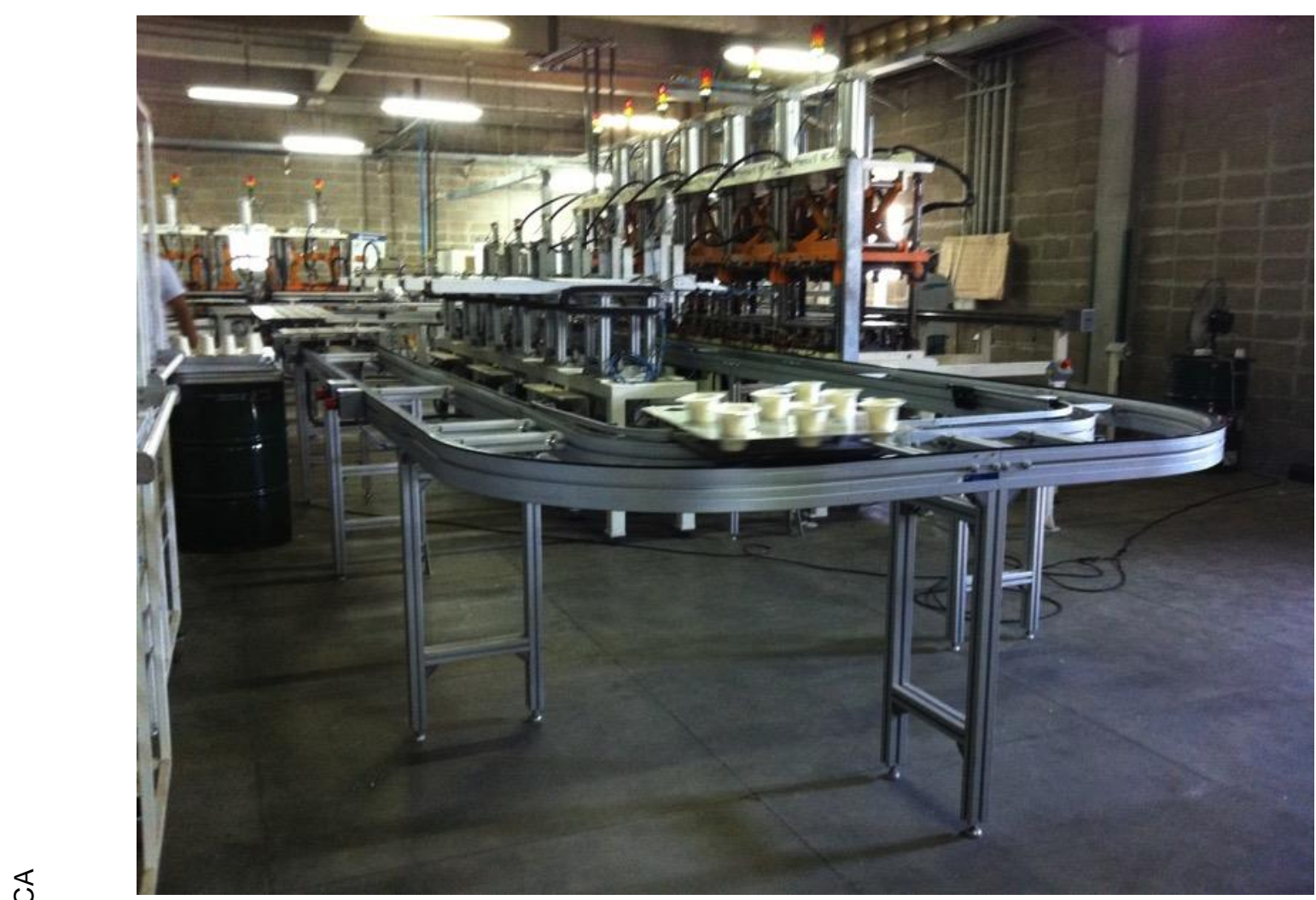

Figura 7 - máquina de termoexpansão de produção de copos da CBPAK

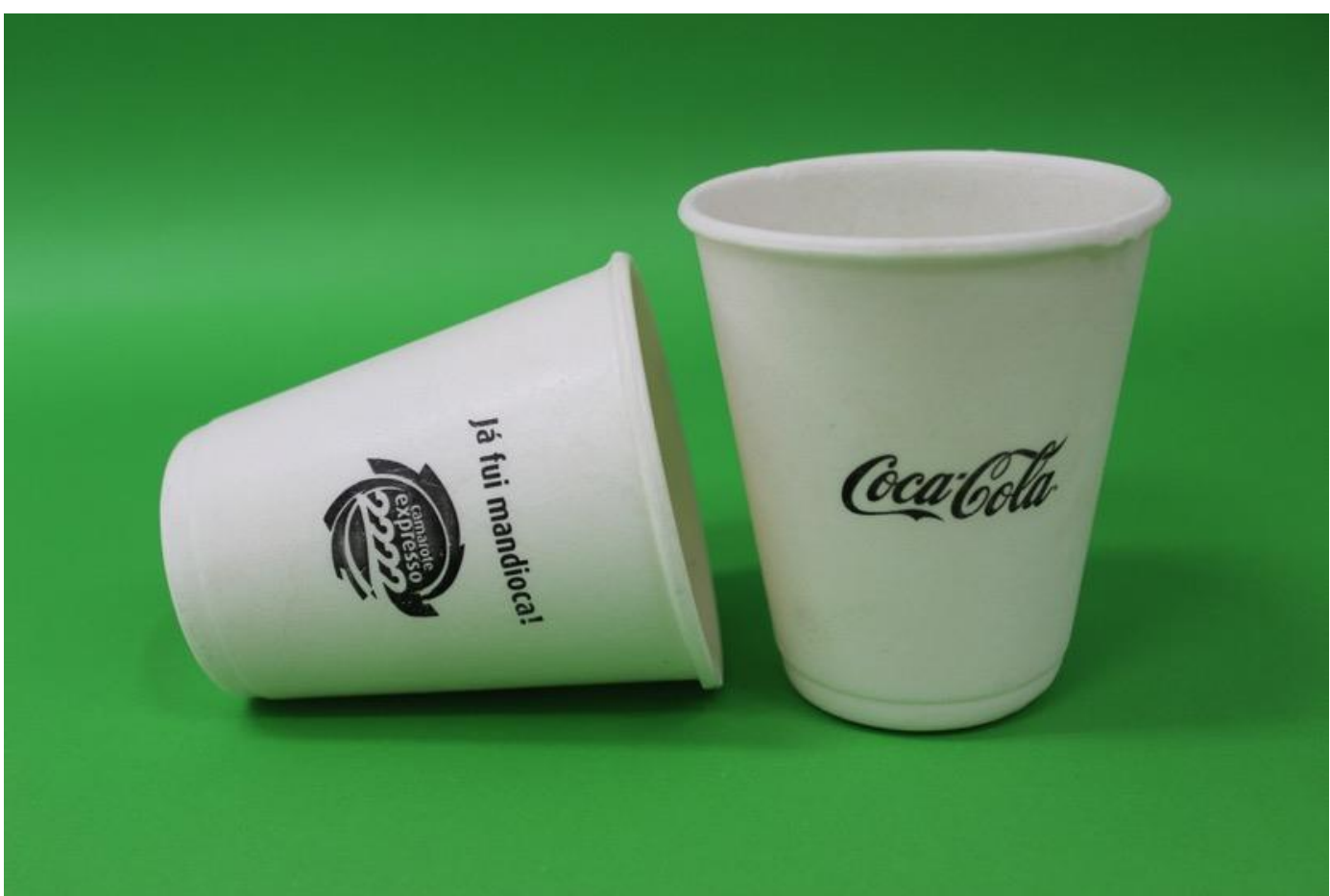

Figura 8 - copos compostáveis de mandioca da CBPAK 


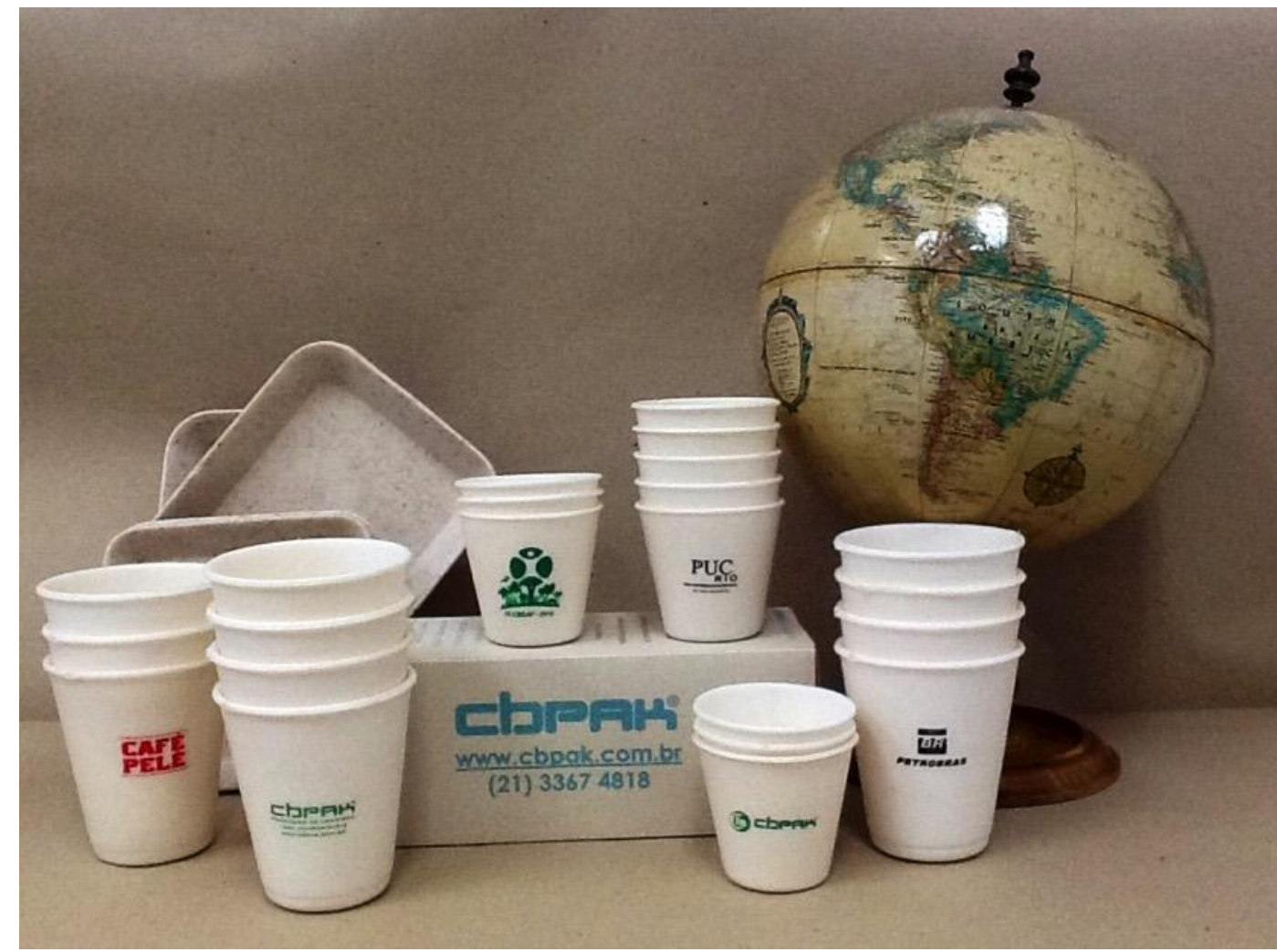

Figura 9 - produtos da CBPAK

\section{II) Os copos de plástico}

A principal fornecedora de resinas plásticas - matéria-prima dos copos de plástico - é a Braskem (www.braskem.com.br), empresa líder do setor na América latina. A organização ECOINVENT (www.ecoinvent.org, Zurique - Suíça), líder mundial em estudos de inventário de ciclo de vida de produto, realizou, para a Braskem, um estudo de ciclo de vida da produção das resinas plásticas. A Braskem, a pedido da CBPAK, para atender ao estudo da Green Domus, disponibilizou dados de emissões de GEE no processo de fabricação das resinas, desde a extração do petróleo até a produção de nafta nas refinarias e das resinas em si, incluindo as emissões oriundas do transporte. A Green Domus adicionou a esses dados os das emissões de GEE no processo industrial de produção dos copos de plástico, que têm o poliestireno como resina plástica. 


\section{3.}

\section{Metrificação do ciclo do produto}

\subsection{1. Premissas para cálculo das emissões e da fixação de carbono}

As premissas abaixo balizaram a métrica de cada etapa do ciclo de produção dos copos, tanto dos de mandioca quanto dos de plástico, no cálculo das emissões e da fixação de carbono.

\section{I) Copos de mandioca}

a) Na produção (fontes: Bahiamido e CBPAK):

- Para se obter 60,0 t de fécula de mandioca, foram necessárias 231,0 $\mathrm{t}$ de mandioca (in natura); portanto, 3,85 $\mathrm{t}$ de mandioca produzem 1,0 t de fécula de mandioca;

- Segundo os dados de 2013: 60,0 t de fécula foram transformadas em 5.258.545 copos de mandioca; portanto, o consumo de fécula de mandioca por copo é $11,41 \mathrm{~g}$.

b) Nas distâncias (fontes: Bahiamido e CBPAK):

- Da plantação até o beneficiamento (fecularia) - 50,0 km;

- Da fecularia até o transformador (CBPAK) - 860,0 km.

c) Nos combustíveis e suas emissões:

- Valores de poder calorífico e de densidade fornecidos pelo Balanço Energético Nacional (BEN 2030);

- Dados de emissão de combustão móvel fornecidos pelo Ministério da Ciência e Tecnologia e Inovação - MCTI;

- Valores para as emissões da rede de distribuição brasileira (sistema SIN) fornecidos pela Comissão Interministerial de Mudança Global do Clima - CIMGC, do MCTI;

d) No Potencial de Aquecimento Global (PAG):

- O PAG dos GEE emitidos é o preconizado pela UNFCC ("United Nations Framework Convention on Climate Change www.newsroom.unfcc.int) para 100 anos - conversão das emissões de cada GEE em $\mathrm{CO}_{2}$ eq. 
e) No cálculo das emissões:

- Emissões de GEE calculadas pela multiplicação da quantidade de combustível consumida pelo seu fator de emissão (para cada gás de efeito estufa).

f) Parâmetros para os cálculos:

- Matéria-prima (fontes: Bahiamido e CBPAK)

i. Decorrentes do plantio e colheita da mandioca (preparo da área, plantio e cultivo, tratos culturais e colheita);

ii. Decorrentes do beneficiamento da mandioca (descarga e processamento do amido, lavador, tanque de correção do $\mathrm{PH}$, tanque de decantação do lodo, prensa hidráulica, lagoa de tratamento, moagem, extração, silagem, purificação, concentração, modificação do amido, filtragem, secagem, classificação e ensaque).

- Transporte da mandioca e/ou fécula:

i. Do plantio até o beneficiamento;

ii. Do beneficiamento até o transformador;

iii. Processo produtivo dos copos de mandioca - as emissões do processo produtivo da CBPAK são pelo consumo de eletricidade e queima de etanol na frota própria de veículos.

g) Fixação de carbono da mandioca:

- A "Food Science and Technology - Campinas web" foi a fonte da informação do teor de carbono em percentagem de matéria seca na fécula da mandioca.

\section{II) Copos de plástico}

a) Na produção (fontes: Ecoinvest e Braskem):

- A emissão de carbono, representada por $\mathrm{CO}_{2}$ eq. , por tonelada de poliestireno produzido é de 3,59 t $\mathrm{CO}_{2}$ eq.;

- O peso de um copo de poliestireno de $300 \mathrm{ml}$ é de 4,54 g;

- A equivalência, em peso de um copo de mandioca (se comparado ao de poliestireno) de igual volume (300 ml) é de 11,41 g; 
- Foi considerada na produção dos copos de plástico apenas a energia elétrica consumida;

- A produção ocorreu em uma extrusora modelo FJL-PC-90-B da ZF Machinery Co., de 90 KW de potência e capacidade de 100 kg/h;

- Portanto, em uma hora, são produzidos 22.026 copos/h consumindo $90 \mathrm{kWh}$ de energia, ou seja, 4,09 Wh por copo;

- O fator médio de emissão de $\mathrm{CO}_{2}$ eq. na produção de eletricidade é de $0,0960 \mathrm{t} \mathrm{CO}_{2}$ eq. $/ \mathrm{MWh}$. (Fonte: estudo da Green Domus para a CBPAK)

\subsection{2.}

\section{Equações para as emissões de Gases de Efeito Estufa}

\section{I) Copos de mandioca}

A relação das equações, fatores de emissão, parâmetros e cálculos para cada etapa para se determinar as emissões de GEE expressas em $\mathrm{CO}_{2}$ eq. são:

\section{- Do plantio e colheita:}

- $\mathbf{E}_{\mathrm{pcM}}$ - Emissões referentes ao Plantio e Colheita da Mandioca expressas em $\mathrm{kg} \mathrm{CO}_{2}$ eq. $/ \mathrm{t}$;

- $\quad \mathbf{E}_{\mathrm{pcFM}}$ - Emissões referentes à transformação em Fécula da Mandioca expressas em $\mathrm{kg} \mathrm{CO}_{2}$ eq. $/ \mathrm{t}$;

- $\boldsymbol{C}_{M}$ - consumo de mandioca (em toneladas) para se produzir 1 tonelada de fécula de mandioca

- Por copo produzido:

$$
\boldsymbol{E}_{p c F M}=\boldsymbol{E}_{p c M} x \boldsymbol{C}_{M}
$$

\section{Do beneficiamento:}

- $\mathbf{E}_{\text {Benef_FM }}$ - Emissões referentes ao Beneficiamento da Fécula de Mandioca expressas em $\mathrm{kg} \mathrm{CO}_{2}$ eq./t de fécula.

- Por copo produzido:

$$
\boldsymbol{E}_{\text {Benef_FM/COPO }}=\boldsymbol{E}_{\text {Benef_FM }} / \text { quantidade de copos }
$$




\section{Do transporte:}

- $\mathrm{C}_{\mathrm{D} / \mathrm{V}}$ - Consumo do combustível Diesel por Viagem - representação aritmética do número de viagens multiplicado pela distância $(\mathrm{km})$ entre os dois pontos (origem e destino do produto), dividido pelo coeficiente de consumo médio de combustível $(\mathrm{km} / \mathrm{l})$ de acordo com índices do Ministério do Meio Ambiente:

- $\mathrm{Q}_{\mathrm{V}}$ - viagens realizadas por ano;

- Dist $_{\mathrm{PC}-\mathrm{FM}}$ - distância percorrida por viagem (ida e volta).

- Coef ${ }_{\text {Diesel }}$ - coeficiente de consumo médio dos caminhões:

$$
C_{\text {D/plantio_colheita }}=Q V \times \text { DistPC,FM / Coef } f_{\text {Diesel }}
$$

- $\mathbf{E}_{\text {transporte/beneficiam. - Emissões referentes ao Transporte da Mandioca }}$ do plantio à fecularia (Bahiamido) expressas em $\mathrm{g} \mathrm{CO}_{2}$ eq. /copo;

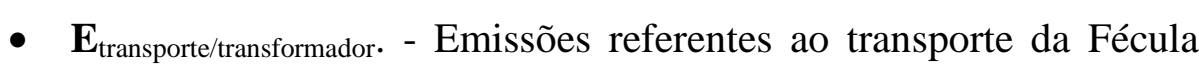
de Mandioca do beneficiamento até o transformador (CBPAK) expressas em $\mathrm{g} \mathrm{CO}_{2}$ eq. /copo.

\section{Do processo produtivo:}

- $\mathbf{E}_{\text {produção_CBPAK }}$ - Emissões referentes à produção dos copos na CBPAK expressas em $\mathrm{g} \mathrm{CO}_{2}$ eq. $/$ copo.

\section{II) Copos de plástico}

\section{Na obtenção do poliestireno:}

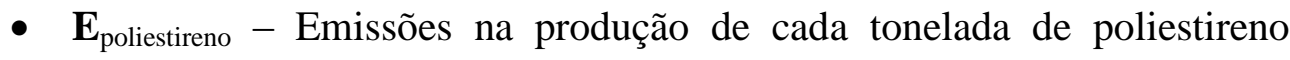
produzida, expressas em tonelada de dióxido de carbono ( $\mathrm{C}_{2}$ eq.); (fontes: Ecoinvest e Braskem);

- $\quad \mathbf{E}_{\text {copo_plástico_MP }}$ - Emissões na produção de cada copo de plástico em função do poliestireno produzido, expressas em toneladas de dióxido de carbono ( $\mathrm{g} \mathrm{CO}_{2}$ eq. copo):

$\boldsymbol{E}_{\text {copo_plástico_MP }}=\boldsymbol{E}_{\text {poliestireno }}$ x peso do copo $\left(\mathrm{g} \mathrm{CO}_{2}\right.$ eq./copo $)$ 


\section{Na produção dos copos:}

- $\quad \mathbf{E F}_{\text {grid_2013 }}$ - Fator médio de emissões de $\mathrm{CO}_{2}$ eq. do grid em 2013, que é de 0,0960 t $\mathrm{CO}_{2}$ eq. $/ \mathrm{MWh}$ :

$\boldsymbol{E}_{\text {copo_plástico_produzido }}=$ Consumo de energia $x \boldsymbol{E F}_{\text {grid,2013 }}\left(\mathrm{g} \mathbf{C O}_{\mathbf{2}}\right.$ eq. $/$ /copo $)$

\subsection{3.}

\section{Emissão de Gases de Efeito Estufa}

\section{I) Copos de mandioca}

A métrica para se obter a pegada dos GEE do copo de mandioca é a seguinte:

- No plantio, colheita e beneficiamento da mandioca - dividem-se as emissões ( $\mathrm{kg} \mathrm{CO}_{2}$ eq. /t de fécula) de cada fonte do ciclo de produção pelo número de copos produzidos com 1 (uma) tonelada de fécula de mandioca;

- No transporte e na fabricação dos copos de mandioca - dividem-se as emissões ( $\mathrm{kg} \mathrm{CO}_{2}$ eq. /ano) de cada fonte do ciclo de produção pelo número de copos produzidos no ano.

A quantidade anual de copos de mandioca utilizada é de 5.258.545 copos, como apontado nas premissas.

\section{Do plantio e colheita:}

Com base nos dados da Bahiamido e da Green Domus, foram determinados os parâmetros e referenciais, cujo resultado é mostrado na Tabela 3 abaixo:

Tabela 3 - Emissões de GEE do plantio à colheita da mandioca

\begin{tabular}{lc}
\hline \multicolumn{1}{c}{ Etapas } & Emissões $\left(\mathrm{kg} \mathrm{CO}_{2}\right.$ eq. $/ \mathrm{t}$ de mandioca) \\
\hline \hline Preparo da terra & 14,53 \\
Plantio e cultivo & 26,87 \\
Tratos culturais & 5,19 \\
Colheita & 8,07 \\
TOTAL & $\mathbf{5 4 , 6 6}$ \\
\hline
\end{tabular}




\section{Cálculo das emissões:}

$\mathrm{E}_{\mathrm{pcM}}=\mathbf{5 4 , 6 6} \mathrm{kg} \mathrm{CO} 2$ eq. $/ \mathrm{t}$ de mandioca

$\mathrm{E}_{\mathrm{pcFM}}=54,66 \times 3,85=\mathbf{2 1 0}, \mathbf{4 4} \mathrm{kg} \mathrm{CO} 2$ eq. $/ \mathrm{t}$ de fécula

Nessa etapa (plantio e colheita), cada tonelada de fécula de mandioca emite 210,44 $\mathrm{kg} \mathrm{CO}_{2}$ eq. $/ \mathrm{t}$ de fécula.

\section{Por copo:}

$\mathrm{E}_{\mathrm{pcFM}} / \mathrm{copo}=\mathbf{E}_{\text {Benef_FM }} /$ quantidade de copos produzido com $1 \mathrm{t}$ de fécula

$\mathrm{E}_{\mathrm{pcFM}} / \mathrm{copo}=210,44 \mathrm{~kg} \mathrm{CO} 2$ eq. $/$ por $\mathrm{t}$ de fécula $/ 87.642$ copos

$\mathrm{E}_{\mathrm{pcFM}} / \mathrm{copo}=\mathbf{2 , 4 0} \mathrm{g} \mathrm{CO}_{2}$ eq. $/$ copo

\section{Do beneficiamento:}

A Tabela 4 abaixo representa as várias etapas do processo nas fecularias para se transformar a mandioca in natura, recebida do plantio, em fécula.

\section{Tabela 4 - Emissões de GEE no beneficiamento da mandioca nas fecularias}

\begin{tabular}{lc}
\hline \multicolumn{1}{c}{ Etapas } & Emissões $\left(\mathbf{k g ~ C O}_{2}\right.$ eq. / t de fécula) \\
\hline \hline Descarga e processamento do amido & 4,73 \\
Lavador & 4,46 \\
Tanque de correção do PH & 1,66 \\
Tanque de decantação do lodo & 3,99 \\
Prensa hidráulica & 3,21 \\
Lagoa de tratamento & 105,11 \\
Moagem & 11,53 \\
Extração & 9,80 \\
Silagem & 4,54 \\
Purificação & 5,12 \\
Concentração & 7,23 \\
Modificação do amido & 427,68 \\
Filtro e vácuo & 3,76 \\
Secagem & 20,58 \\
Classificador & 0,90 \\
Ensaque & 2,48 \\
TOTAL & $\mathbf{6 1 6 , 8 0}$ \\
\hline
\end{tabular}

\section{Cálculo das emissões:}

$\mathrm{E}_{\text {Benef_Mandioca/COPO }}=\mathbf{E}_{\text {Benef_Mandioca }} /$ quant. de copos por tonelada de fécula

$\mathrm{E}_{\text {Benef_Mandioca/COPO }}=616,8 \mathrm{~kg} \mathrm{CO} 2$ eq. $/ 87.642$ copos

$\mathbf{E}_{\text {Benef,Mandioca/ } \mathrm{COPO}}=\mathbf{7 , 0 4} \mathrm{g} \mathrm{CO}_{2}$ eq. $/$ copo 


\section{Do transporte:}

Da mandioca (in natura) da área de plantio e colheita até a fecularia:

- $\mathrm{Q}_{\text {Viagens }}=23$ viagens realizadas por ano

- Dist $_{\text {PC_FM }}=50 \mathrm{~km}$ por viagem (ida e volta)

- Coef $_{\text {Diesel }}=5,56 \mathrm{~km} / \mathrm{l}$ (fonte: Ministério do Meio Ambiente)

\section{Cálculo das emissões:}

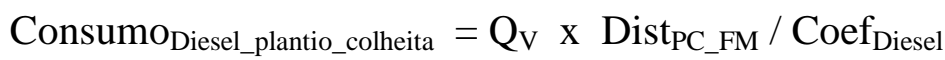

Consumo $_{\text {Diesel_plantio_colheita }}=23$ viagens $x 50 \mathrm{~km} / 5,56 \mathrm{~km} / 1$

O consumo de óleo Diesel consumido anualmente no transporte da mandioca até o beneficiamento é de 208 litros.

Da fecularia (Bahiamido) para o transformador (CBPAK)

- $\mathrm{Q}_{\text {Viagens }}=6$ viagens realizadas por ano

- Dist $_{\mathrm{PC}, \mathrm{FM}}=860 \mathrm{~km}$ por viagem (ida e volta)

- Coef $_{\text {Diesel }}=5,56 \mathrm{~km} / \mathrm{l}$ (fonte: Ministério do Meio Ambiente)

Consumo $_{\text {Diesel_beneficiam. }}=\mathrm{Q}_{\mathrm{V}} \mathrm{x}$ Dist $_{\text {Benef/transf. }} /$ Coef $_{\text {Diesel }}$

Consumo $_{\text {Diesel_plantio_colheita }}=6$ viagens $\times 860 \mathrm{~km} / 5,56 \mathrm{~km} / 1$

O consumo de óleo Diesel consumido anualmente no transporte da fécula de mandioca (Bahiamido) até o transformador (CBPAK) é de 928 litros.

A Tabela 5 abaixo consolida os cálculos efetuados.

Tabela 5 - Emissões de GEE no transporte

\begin{tabular}{|c|c|c|c|c|c|c|}
\hline \multirow{2}{*}{$\begin{array}{l}\text { Fonte de } \\
\text { emissão }\end{array}$} & \multirow{2}{*}{$\begin{array}{l}\text { Qte } \\
\text { ( I ) }\end{array}$} & \multicolumn{4}{|c|}{ Emissões } & \multirow{2}{*}{$\begin{array}{l}\begin{array}{l}\text { Emissões de } \\
\text { biomassa }\end{array} \\
\mathrm{kg} \mathrm{CO}_{2}\end{array}$} \\
\hline & & $\mathrm{kg} \mathrm{CO}$ & $\mathrm{kg} \mathrm{CH}$ & $\mathrm{kg} \mathrm{N}_{2} \mathrm{O}$ & $\mathrm{kg} \mathrm{CO}_{2 \text { eq. }}$ & \\
\hline Óleo Diesel & 208 & 527,11 & 0,04 & 0,00 & 529,5 & 25,96 \\
\hline Óleo Diesel & 928 & $2.354,9$ & 0,20 & 0,02 & $2.365,5$ & 115,96 \\
\hline
\end{tabular}

O cálculo das emissões utiliza o volume anual de copos produzidos com $60 \mathrm{t}$ de fécula mandioca, que é de 5.258.545 copos/ano. 
$\mathbf{E}_{\text {Transporte/benef./COPO }}=$ Emissão de $\mathrm{kg} \mathrm{CO}_{2}$ eq. $/$ quantidade de copos produzidos no ano, com $60 \mathrm{t}$ de fécula

$\mathbf{E}_{\text {Transporte/benef./COPO }}=529,49 \mathrm{~kg} \mathrm{CO}_{2}$ eq. $/ 5.258 .545 \mathrm{copos}$

$\mathbf{E}_{\text {Transporte/benef. /COPO }}=\mathbf{0 , 1 0} \mathrm{g} \mathrm{CO}_{2}$ eq. $/$ copo

$\mathbf{E}_{\text {Transporte/transf./COPO }}=$ Emissão de $\mathrm{kg} \mathrm{CO}_{2}$ eq. $/$ quantidade de copos produzidos no ano com $60 \mathrm{t}$ fécula

$$
\begin{aligned}
& \mathbf{E}_{\text {Transporte/transf./COPO }}=2.365,5 \mathrm{~kg} \mathrm{CO} \text { eq. } / 5.258 .545 \text { copos } \\
& \mathbf{E}_{\text {Transporte/transf./COPO }}=\mathbf{0 , 4 4 9 8} \mathrm{g} \mathrm{CO}_{2 \text { eq. }} / \text { copo } \\
& \mathbf{E}_{\text {TOTAL do plantio ao transform. /COPO }}=\mathbf{E}_{\text {Transporte/benef. } / \mathrm{COPO}}+\mathbf{E}_{\text {Transporte/transf./COPO }}
\end{aligned}
$$

A emissão total de GEE, por copo, no transporte da origem (plantio) à transformação em copos (destino final), é de:

$$
\mathbf{0 , 1 0}+\mathbf{0 , 4 4 9 8}=\mathbf{0 , 5 4 9 8} \mathrm{g} \mathrm{CO}_{2 \text { eq. }} / \text { copo }
$$

\section{Do processo produtivo (CBPAK):}

- Total de energia elétrica anual importada da rede de distribuição (2013) para a produção dos copos na CBPAK $=234.168 \mathrm{kWh}$

- Total anual de etanol hidratado utilizado para abastecer a frota de veículos da CBPAK = 5.072,46 litros

\section{Cálculo das emissões}

A Tabela 6 abaixo sumariza as emissões de GEE para a energia elétrica e o etanol hidratado consumidos anualmente para a produção de 5.528.545 copos de mandioca (item a das premissas). A fonte de informação dos fatores de emissão de

\begin{tabular}{|c|c|c|c|c|}
\hline Fonte de emissão & Quantidade & Unidade & $\begin{array}{c}\text { Emissões } \\
\left(\mathbf{k g ~ C O} \mathrm{CO}_{2 \text { eq. }}\right)\end{array}$ & $\begin{array}{c}\text { Emissões por biomassa } \\
\left(\mathbf{k g ~ C O} \mathrm{Cl}_{2} \text { eq.) }\right.\end{array}$ \\
\hline Energia elétrica & $234.168,0$ & $\mathrm{kWh}$ & 22.488 & \\
\hline Etanol hidratado & $5.072,46$ & litros & 77,50 & $5.975,36$ \\
\hline TOTAL & & & $22.565,5$ & $5.975,36$ \\
\hline
\end{tabular}
GEE tanto para o etanol hidratado quanto para a eletricidade foi o Ministério da Ciência, Tecnologia e Informação (MCTI - 2010).

Tabela 6 - Emissões de GEE no consumo de energia 
$\mathbf{E}_{\text {produção_CBPAK }}$ - Emissões referentes à produção dos copos na CBPAK expresso em $\mathrm{g} \mathrm{CO}_{2}$ eq. total copos produzidos no ano

$$
\mathbf{E}_{\text {produção_CBPAK }}=22.565,5 / 5.258 .545=\mathbf{4 , 2 9 1 2} \mathrm{g} \mathrm{CO}_{2 \text { eq. }} / \text { copo }
$$

A Tabela 7 sumariza as emissões de GEE expressas em gramas de dióxido de carbono equivalente $\left(\mathrm{g} \mathrm{CO}_{2}\right.$ eq $)$ por copo de mandioca, em todas as etapas. $\mathrm{O}$ que se fez foi dimensionar para cada etapa a fonte de emissões e trazer a uma mesma unidade de copos, fossem elas produzidas por cada tonelada de fécula de mandioca ou produzidas por ano na CBPAK.

Tabela 7 - Emissões totais de $\mathrm{CO}_{2}$ eq./copo em todo o processo

\begin{tabular}{|c|c|c|c|}
\hline Fonte de emissões & $\begin{array}{c}\text { Emissões } \\
\text { totais }\end{array}$ & Unidades & $\begin{array}{c}\text { Emissões } \\
\left(\mathrm{g} \mathrm{CO}_{2 \mathrm{eq}} / \mathrm{copo}\right) \\
\end{array}$ \\
\hline Plantio e colheita da mandioca & 210,4 & $\mathrm{~kg} \mathrm{CO} \mathrm{CO}_{2 \text { eq. }} / \mathrm{t}_{\text {fécula }}$ & 2,40 \\
\hline $\begin{array}{l}\text { Transporte da mandioca para a } \\
\text { fecularia }\end{array}$ & 529,5 & $\mathrm{~kg} \mathrm{CO}_{2}$ eq. /ano & 0,10 \\
\hline $\begin{array}{l}\text { Beneficiamento da mandioca } \\
\text { transformando-a em fécula }\end{array}$ & 616,8 & $\mathrm{~kg} \mathrm{CO} 2$ eq. $/ \mathrm{t}_{\text {fécula }}$ & 7,04 \\
\hline $\begin{array}{l}\text { Transporte da fécula para a } \\
\text { CBPAK }\end{array}$ & $2.365,5$ & $\mathrm{~kg} \mathrm{CO}_{2}$ eq /ano & 0,45 \\
\hline $\begin{array}{l}\text { Fabricação dos copos de } \\
\text { mandioca na CBPAK }\end{array}$ & $22.565,5$ & $\mathrm{~kg} \mathrm{CO}_{2}$ eq /ano & 4,29 \\
\hline TOTAL das emissões por copo & & & 14,28 \\
\hline
\end{tabular}

Cada copo de mandioca produzido representa, portanto, uma emissão de $14,28 \mathrm{~g} \mathrm{CO}_{2}$ eq. .

\section{II) Copos de plástico}

Na obtenção do poliestireno:

- A emissão de GEE para se produzir 1 (uma ) tonelada de

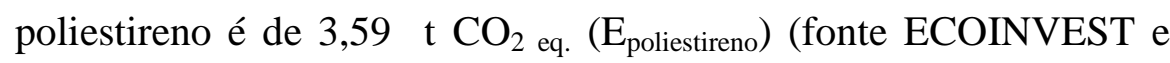
BRASKEM);

- O peso de um copo plástico de poliestireno de $300 \mathrm{ml}$ é de 4,54 g, o que equivale a 11,41 $\mathrm{g}$ em peso de fécula de mandioca.

\section{Cálculo das emissões:}

$\boldsymbol{E}_{\text {copo_plástico_MP }}=\boldsymbol{E}_{\text {poliestireno }} x$ peso do copo $\left(\mathrm{g} \mathrm{CO}_{2}\right.$ eq./copo $)$

$\boldsymbol{E}_{\text {copo_plástico_MP }}=3,59 \times 4,54=\mathbf{1 6 , 3 0} \mathrm{g} \mathrm{CO}_{2}$ eq. $/$ copo 


\section{Na produção dos copos:}

Foi considerada apenas a energia elétrica consumida no cálculo das emissões de GEE na produção dos copos de plástico (poliestireno de $300 \mathrm{ml}$ ). Segundo cálculos baseados nas informações do fabricante da extrusora (premissas no item a acima), o consumo de energia é de 4,09 Wh/copo.

O fator médio de emissões de $\mathrm{CO}_{2}$ eq./do grid em 2013 ( $\left.\mathbf{E F}_{\text {grid,2013 }}\right)$ é de 0,0960 t $\mathrm{CO}_{2 \text { eq./IMh. }}$

\section{Cálculo das emissões:}

$\mathbf{E}_{\text {copo_plástico_PRODUZIDO }}=$ Consumo de energia $x \mathbf{E F}_{\text {grid_2013 }}\left(\mathrm{g} \mathrm{CO}_{2 \text { eq././copo }}\right)$

$\mathbf{E}_{\text {copo_plástico_PRODUZIDO }}=4,09 \times 0,096=\mathbf{0 , 3 9} \mathrm{g} \mathrm{CO}$ eq./Copo

Em conclusão: a emissão total de GEE (do berço ao portão) na produção de copos plásticos é de $\mathbf{1 6 , 3 0} \mathrm{g} \mathrm{CO}_{2}$ eq./ copo na produção da matéria-prima, mais 0,39 $\mathrm{g} \mathrm{CO}_{2}$ eq./ copo na produção dos copos, totalizando $\mathbf{1 6 , 6 9} \mathrm{g} \mathrm{CO}_{2}$ eq./ copo.

\subsection{4.}

\section{Métrica para a fixação de carbono}

\section{I) Copos de mandioca}

Fixação de carbono pela mandioca:

O teor de carbono em percentagem de matéria seca na fécula da mandioca é de 43,08\%. (fonte: Food Science and Technology - Campinas web https://www.google.com.br/search?q=quantidade+de+carbono+fixada+na+mandi oca\&rlz=1C2SAVI_enBR532BR532\&tbm=isch\&tbo=u\&source=univ\&sa=X\&ei =zp-2U7f3IO_msATp9YHIBQ\&ved=0CFEQsAQ\&biw=1280\&bih=923).

\section{Quantidade de emissões de dióxido de carbono (CO2) evitadas:}

1 tonelada de fécula de mandioca contém 430,8 kg de carbono.

$\mathbf{E}_{\text {evitadas- fécula }}$ Emissões evitadas por tonelada de fécula produzida:

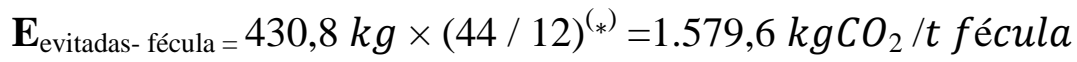

$\left.{ }^{*}\right)$ Razão entre o peso molecular do $\mathrm{CO}_{2}$ e do Carbono 
$\mathbf{E}_{\text {evitadas- fécula }=1,5796 \mathrm{~g} \mathrm{CO}_{2} \text { eq./g fécula }}$

Considerando que cada copo de mandioca contem 11,41 g de fécula

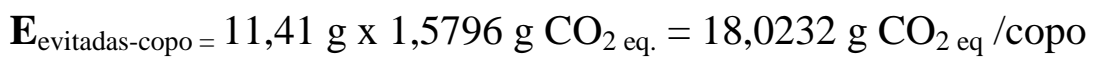

$E_{\text {evitadas-copo }}=18,0232 \mathrm{~g} \mathrm{CO}_{2 \text { eq }} /$ copo

\section{II) Copos de plástico}

Não se aplica. O processo de obtenção do petróleo não fixa carbono.

\subsection{5.}

\section{Balanço das emissões de GEE}

O comparativo apresentado na Tabela 8 abaixo levou em consideração todas as etapas do processo, desde a obtenção da matéria-prima até a produção dos copos na fábrica.

Tabela 8 - Comparativo das emissões de GEE

\begin{tabular}{ccccc}
\hline $\begin{array}{c}\text { Tipo de } \\
\text { copo }\end{array}$ & Emissões liberadas & Emissões evitadas & Balanço final & $\begin{array}{c}\mathbf{C O}_{2 \text { eq. }} \text { por } \\
\text { copo }\end{array}$ \\
\hline \hline Mandioca & 14,28 & 18,02 & SEQUESTRA & $-3,74$ \\
Plástico & 16,69 & 0 & EMITE & $+16,69$ \\
\hline
\end{tabular}

\subsection{6.}

\section{Consumo de água}

\section{I) Copos de mandioca}

De acordo com a CBPAK, o consumo de água no processo industrial é mínimo. É utilizada apenas para resfriar alguns mancais das prensas hidráulicas. Os moldes não precisam de água de refrigeração. Considerando as perdas, o consumo médio de água por copo de mandioca produzido é de $8 \mathrm{ml} / \mathrm{copo}$, o que equivale a $0,000008 \mathrm{~m}^{3}$. 


\section{II) Copos de plástico}

O Professor Bruno Fernando Gianelli, do Instituto Federal de Educação, Ciência e Tecnologia de São Paulo (IFSP) - Campus Itapetininga, em palestra sobre a crise hídrica e o uso de copos descartáveis de plástico para os alunos do Programa de Pós-Graduação em Engenharia Civil e Ambiental da Universidade Estadual Paulista - campus Sorocaba, afirmou:

Um copo descartável necessita de água em duas etapas de sua produção:

Etapa 1 - a de menor consumo, está relacionada ao processo de produção propriamente dito e é incorporada ao produto final. Neste caso estamos falando de um consumo de $50 \mathrm{ml}$ por copo produzido;

Etapa 2 - a de maior consumo, relaciona-se com a refrigeração do processo de fabricação, pois tais copos são produzidos por termoformação e tanto o equipamento, quanto os copos necessitam ser resfriados. Neste caso o consumo de água é $3.150 \mathrm{ml}$ por copo produzido. (Gianelli, B. "Avaliação do Ciclo de Vida e o Impacto Ambiental de Produtos e Serviços". Apresentação não publicada. São Paulo, UNESP: 2014).

No entanto, de fato, com relação à etapa 2, muitas empresas empregam um sistema de recirculação de água, o que minimiza significativamente o consumo. Se devidamente calibrados, tais sistemas fazem com que a perda de água decorrente do processo de resfriamento seja de $10 \%$ a $20 \%$ do consumo inicial. Ou seja, a perda de água dessa etapa estaria entre 315 e $620 \mathrm{ml}$, ou, em média 450 $\mathrm{ml}$ por copo produzido.

No presente estudo, negligenciando-se a primeira etapa, adotou-se como referencial o indicador de $450 \mathrm{ml}\left(0,00045 \mathrm{~m}^{3}\right)$ de água de processo na fabricação de 1 (um) copo de poliestireno.

\subsection{7. \\ Balanço do consumo de água}

A Tabela 9 abaixo resume as informações sobre o consumo de água na etapa de fabricação dos copos, tanto para a fabricação em si como principalmente para o resfriamento das máquinas e moldes, incluindo as perdas (evaporação e outras).

Tabela 9 - Consumo de água na produção dos copos descartáveis

\begin{tabular}{cc}
\hline Tipo de copo & $\mathbf{m l} / \mathbf{c o p o}$ \\
\hline \hline Mandioca & 8,0 \\
Plástico & 450,0 \\
\hline
\end{tabular}




\section{4.}

\section{Monetização do ciclo do produto}

\subsection{1. Princípio da substituição}

Para o estudo da monetização do ciclo de vida dos copos descartáveis, foi adotado o princípio da substituição, pela incorporação das externalidades positivas, representadas por:

- Emissão de carbono;

- Consumo de água;

- Descarte em aterro.

O princípio é reduzir o desperdício de copos descartáveis, principalmente os de plástico, pela conscientização quanto ao consumo, segundo princípios da educação ambiental. Nesses termos, levar-se-á em conta no presente estudo uma taxa de substituição de 1 (um) copo de mandioca para cada 2 (dois) copos de plástico.

\subsection{2.}

\section{Indicadores de impacto ambiental}

Os indicadores financeiros adotados para monetização estão relacionados à:

- Neutralização ou redução das emissões de GEE, expressos em $\mathrm{t} \mathrm{CO}_{2}$ eq.;

- Consumo de água de processo, $\mathrm{em}^{3}$;

- Eliminação da necessidade de área ou volume em aterro sanitário, em $\mathrm{m}^{2}$ ou $\mathrm{m}^{3}$;

- Custo para compra dos copos descartáveis (mandioca e plástico).

\subsection{3.}

Neutralização de carbono

A emissão de GEE tem o seu antidoto na neutralização pela compensação de $\mathrm{CO}_{2}$ eq. A compensação mais utilizada é via plantio de árvores, os únicos seres vivos capazes de consumir o $\mathrm{CO}_{2}$ da atmosfera e realizar a fotossíntese. No presente estudo, foram adotadas informações da ONG Onda Verde (RJ) 
(www.ondaverde.com.br) para os cálculos de compensação de emissões de GEE através do plantio de árvores.

\section{Premissas:}

- Etapas do processo - plantio no ano 1 e 3 (três) visitas anuais nos anos 2 e 3, para manutenção;

- Custo de plantio - R\$18,00/muda. Densidade de 2.500 mudas/ha. Custo total de R\$ 45.000/há;

- Custo de manutenção (inclui a substituição) - R \$12,00/muda/visita x 3 vistas/ano = R \$ 90.000/ano/há;

- Custo total por árvore - $\mathrm{R} \$ 90,00 / a ́ r v o r e ;$

- Em um período de 20 anos, sete árvores sequestram (fixa) 1 (uma) tonelada de $\mathrm{CO}_{2}$.

Baseado nessas premissas, conclui-se que, para compensar $1 \mathrm{t} \mathrm{CO}_{2}$, é necessário plantar 7 (sete) árvores, que, ao custo de R \$90,00/árvore, fornece um custo total de $\mathbf{R} \$ \mathbf{6 3 0 , 0 0 / t} \mathbf{C O}_{2}$ compensado.

\subsection{4.}

\section{Água de processo}

De acordo com informações publicadas pelo Sistema Nacional de Informação sobre Saneamento - SNIS (julho 2013), o custo do metro cúbico de água na cidade do Rio de Janeiro é de $\mathbf{R} \$ \mathbf{3 , 1 6} / \mathbf{m}^{3}$. O abastecimento é realizado pela concessionária CEDAE.

\subsection{5. \\ Áreas em aterros sanitários \\ I) Copos de mandioca}

A destinação final dos copos de mandioca é um centro de compostagem ou biodigestores. Na compostagem, os copos agem como o elemento "carbono" no processo, substituindo, em parte, folhas, galhos, madeira, serragem e resíduos orgânicos. O produto final obtido, de valor monetário, é a terra vegetal. No biodigestor os copos de mandioca agem como massa, a ser incinerada para gerar biogás e, na continuação, transformar-se em energia. 
Dessa forma, o copo de mandioca ao ser encaminhado ao seu destino final proporciona a geração de valor monetário, quer pela terra vegetal, quer pelo biogás.

\section{Compostagem}

Os dados para este item foram obtidos da empresa de compostagem industrial VIDE VERDE (www.videverde.com.br), empresa pioneira de compostagem licenciada pelo INEA (RJ), com capacidade para processar 1.200 toneladas de resíduos orgânicos por mês, parte do grupo Venativ Assessoria Ambiental e Comercial Ltda., empresa brasileira especializada em gerenciar resíduos de indústrias, supermercados, empresas, shopping centers, condomínios e outras organizações.

Segundo a Vide Verde, as premissas e indicadores são:

- Para se produzir $4 \mathrm{~m}^{3}$ de composto, é necessário $1 \mathrm{~m}^{3}$ de resíduos sólidos orgânicos secos oriundos dos alimentos descartados, mais $3 \mathrm{~m}^{3}$ de carbono (folhas, serragem, madeira, copos de mandioca, etc.);

- 10.000 copos de mandioca representam $3 \mathrm{~m}^{3}$ de carbono na compostagem;

- O produto final da compostagem (composto ou terra vegetal) apresenta um aproveitamento de $10 \%$, ou seja, $0,4 \mathrm{~m}^{3}$ de composto para cada $4 \mathrm{~m}^{3}$ de material para compostagem;

- $1 \mathrm{~m}^{3}$ de terra vegetal pode ser representado, em massa, por 0,8 tonelada, e é comercializado a R\$200,00/tonelada;

- Logo, $1 \mathrm{~m}^{3}$ de terra vegetal (10.000 copos) pesa $320 \mathrm{~kg}=\mathrm{R} \$ 64,00$.

Para 5.248.545 copos de mandioca/ano, pode-se obter uma receita bruta com a venda da terra vegetal da ordem de $\mathbf{R} \$ \mathbf{3 3 . 5 9 0 , 6 0}$ (valor a ser utilizado no custo ambiental), representando $524,8 \mathrm{~m}^{3}$.

\section{Biodigestão}

A monetização do biogás gerado pela incineração dos copos de mandioca é dada por um estudo técnico da empresa Planotec Biodigestores Ltda. (www.planotec.ind.br). Acrescenta-se um artigo do Engenheiro Paulo Cremonez 
apresentado no II Simpósio de Bioenergia e Biocombustível do Mercosul (25 a 26 de setembro de 2014), com o título "Digestão anaeróbica de polímero orgânico a base de fécula de mandioca diluído em agua residual de suínos", que ratifica as informações da empresa Planotec (Cremonez, 2015).

A Associação Brasileira dos criadores de Suínos - ABCS publicou em sua página na Internet (www.abcs.org.br, vistada pelo autor em 13 de abril de 2015) que a equivalência energética de $1 \mathrm{~m}^{3}$ de biogás equivale energeticamente a:

- $1,5 \mathrm{~m}^{3}$ de gás de cozinha;

- 0,52 a 0,6 litro de gasolina;

- 0,9 litro de álcool;

- 1,43 KWh de energia elétrica;

- $\quad 2,7 \mathrm{~kg}$ de lenha (madeira queimada).

\section{Cálculo:}

- $\quad 1.000$ copos de mandioca geram $14,3 \mathrm{~m}^{3}$ de biogás;

- $1 \mathrm{~m}^{3}$ de biogás equivale, em preço, a 0,9 1 de etanol;

- 1 litro de etanol no RJ custa R \$ 2,95/1 (ago. 2015 - postos da Petrobras).

Para o volume de 5.248.545 copos de mandioca/ano, por simples cálculo, tem-se a geração de $75.054,19 \mathrm{~m}^{3}$ de biogás, que representam em valor monetário R\$ 199.268,88 (67.728,77 litros de etanol hidratado, ao preço de R \$ 2,95 - ago. 2015, em posto da Petrobras na cidade do Rio de Janeiro-RJ).

\section{II) Copos de plástico}

De acordo com publicação recente do Banco Santander, o valor praticado para depósito de resíduos sólidos em aterro sanitário varia de $\mathrm{R} \$ 150,00$ a $\mathrm{R} \$$ 300,00 por tonelada depositada (www.santanderempreendedor.com.br/queroexpandir-o-meu-negocio/sustentabilidade/674-aprenda-adestinar-corretamente-osresiduos-industriais).

Para fins dos cálculos, adotou-se como custo de destinação para aterros sanitários o valor de R \$225,00/t. Na relação de um copo de mandioca para cada dois copos de plástico, tem-se: 
- 5.248.545 copos de mandioca/ano substituem 10.497.090 copos de plástico;

- Ao peso de 4,54 g/copo plástico de $300 \mathrm{ml}$, o peso total é 47,65 t de resíduos sólidos;

- Ao custo de $\mathrm{R} \$ 225 / \mathrm{t}$ na aterragem, o valor anual final é de $\mathbf{R} \$$ $10.722,77$.

No $19^{\circ}$ Congresso Brasileiro de Engenharia Sanitária e Ambiental, realizado em 2006, foi apresentado um trabalho intitulado "Desenvolvimento de um coletor de copos plásticos descartáveis visando à minimização de volume”, pelos professores Maria Zanin e Bernardo Arantes do Nascimento Teixeira, do Departamento de Engenharia de Materiais da Universidade de São Carlos (www.bvsde.paho.org/bvsacd/abes97). Diz lá:

[...] a quantidade de copos plásticos de PS utilizados por dia atinge cerca de 2500 unidades, sendo descartados em média 1700 copos no almoço e 800 copos durante o jantar. Verificou-se também que o volume que esses copos ocupam é da ordem de 11 sacos de lixo de $200 \mathrm{~L}$, ou seja, ocupam um volume total de $2.200 \mathrm{~L}$ de copos residuais por dia [...].

Segundo esses dados, o volume total ocupado por 10.497 .090 copos de plástico é de $9.237,43 \mathrm{~m}^{3}$, que terão como destinação final o aterro sanitário, na melhor das hipóteses.

\subsection{6.}

Custos dos copos descartáveis

\section{I) Copos de mandioca}

O milheiro do copo de mandioca de $300 \mathrm{ml}$ custa $\mathrm{R} \$ 300,00$ (CBPAK).

\section{II) Copos de plástico}

Para os copos de plástico, que são uma commodity, existem muitos fabricantes no país e centenas de distribuidores. A faixa de preço para os copos de $300 \mathrm{ml}$, em poliestireno, é ampla ainda mais por conta de suas especificações técnicas (espessura e tipo) que afetam o seu custo. Pesquisa com vários distribuidores de um determinado tipo dão um preço médio de $\mathrm{R} \$$ 80,00/milheiro. 


\subsection{7.}

\section{Valor monetário final}

Para se estruturar uma tabela comparativa de custos, será utilizado o custo ambiental a ser adicionado ao custo comercial dos produtos.

\section{I) Copos de mandioca}

A Tabela 10 abaixo apresenta o valor monetário para cada indicador de impacto dos copos de mandioca. A demanda de uso de copos anuais adotada no presente estudo é de 5.428 .545 copos de mandioca.

Tabela 10 - Valor monetário dos indicadores de impacto dos copos de mandioca

\begin{tabular}{llrr}
\hline Indicadores & \multicolumn{1}{c}{$\begin{array}{c}\text { Valor de impacto para } \\
\mathbf{5 . 2 4 8 . 5 4 5} \text { copos/ano }\end{array}$} & $\begin{array}{c}\text { Valor monetário de } \\
\text { cada impacto }\end{array}$ & TOTAL \\
\hline \hline $\mathrm{CO}_{2}$ eq. & $\begin{array}{l}5.248 .545 \text { copos } \times 3,74 \mathrm{t} \\
\mathrm{CO}_{2 \text { eq }} / 10^{-6}\end{array}$ & $\mathrm{R} \$ 630,00 / \mathrm{t}$ & $\mathrm{R} \$ 12.366,62$ \\
$\begin{array}{l}\text { Água de } \\
\text { processo }\end{array}$ & $\begin{array}{l}0,000008 \mathrm{~m}^{3} \times 5.248 .545 \\
\text { copos }\end{array}$ & $\mathrm{R} \$ 3,16 / \mathrm{m}^{3}$ & $\mathrm{R} \$ 132,68$ \\
Área em AS & 0 (pela compostagem) & $\mathrm{R} \$ 200,00 / \mathrm{m}^{3}$ & $\mathrm{R} \$ 0,00$ \\
Compostagem & $167,95 \mathrm{t}$ de composto & $\mathrm{R} \$ 200,00 / \mathrm{m}^{3} /$ composto & $\mathrm{R} \$ 53.590,68$ \\
Biogás & $75.054,19 \mathrm{~m}^{3}$ de biogás & $\mathrm{R} \$ 2,65 / \mathrm{m}^{3}$ & $\mathrm{R} \$ 199.268,88$ \\
\hline
\end{tabular}

\section{II) Copos de plástico}

A Tabela 11 abaixo apresenta o valor monetário para cada indicador de impacto dos copos de plástico. A demanda de uso de copos anuais do presente estudo é de 10.497.090 copos de plástico, na métrica da relação 1:2, em relação aos copos de mandioca, proveniente do desperdício dos copos de plástico. 
Tabela 11 - Valor monetário dos indicadores de impacto dos copos de plástico

\begin{tabular}{lcrr}
\hline \multicolumn{1}{c}{ Indicadores } & $\begin{array}{c}\text { Valor de cada impacto para } \\
\mathbf{1 0 . 4 9 7 . 0 9 0} \text { copos/ano }\end{array}$ & $\begin{array}{c}\text { Valor monetário } \\
\text { de cada impacto }\end{array}$ & TOTAL \\
\hline \hline $\mathrm{CO}_{2}$ eq. & 10.497 .090 copos $\mathrm{x} 16,69 \mathrm{t} \mathrm{CO}_{2}$ & $\mathrm{R} \$ 630,00 / \mathrm{t}$ & $\mathrm{R} \$ 110.373,75$ \\
eq. $/ 10^{-6}$ & $\mathrm{R} \$ 3,16 / \mathrm{m}^{3}$ & $\mathrm{R} \$ 14.926,86$ \\
Água processo & $\left(0,00045 \mathrm{~m}^{3} \times 10.497 .090\right.$ copos $)$ & $\mathrm{R} \$ 225,00 / \mathrm{t}$ & $\mathrm{R} \$ 10.722,77$ \\
Área em AS & $47,65 / \mathrm{t}$ & $\mathrm{N} / \mathrm{A}$ & $\mathrm{R} \$ 0,00$ \\
Compostagem & 0 & $\mathrm{~N} / \mathrm{A}$ & $\mathrm{R} \$ 0,00$ \\
Biogás & 0 & &
\end{tabular}

\subsection{8.}

\section{Custo ambiental}

Os dois quadros abaixo mostram os resultados finais. Os números são baseados em uma produção anual (que equivale ao consumo) de 5.248.545 copos de mandioca, que utilizaram 60 toneladas de fécula de mandioca, base do presente estudo. A destacar, a relação de uso de copos plásticos e de copos de mandioca no fator de substituição de 1:2, por conta do desperdício dos copos de plástico.

Do ponto de vista ambiental, o resultado indicado no Quadro 1 abaixo, em uma análise comparativa entre os dois tipos de copos, demonstra a redução dos impactos ambientais.

Quadro 1 - Indicadores ambientais do estudo comparativo

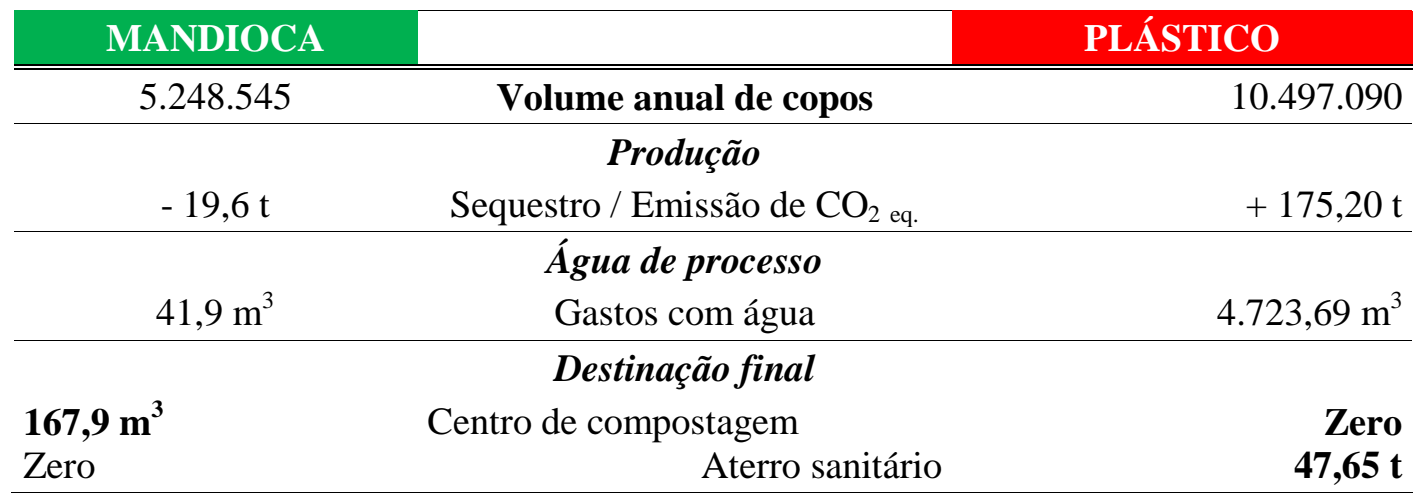

Do ponto de vista financeiro, com a compostagem sendo o destino final dos copos de mandioca: 
Quadro 2 - Comparativo, com compostagem dos copos de mandioca

\begin{tabular}{|c|c|c|}
\hline MANDIOCA & & PLÁSTICO \\
\hline $\mathrm{R} \$ 300,00$ & Preço de venda do milheiro & $\mathrm{R} \$ 80,00$ \\
\hline 5.248 .545 & Volume anual de copos & 10.497 .090 \\
\hline \multirow[t]{2}{*}{$\mathrm{R} \$ 1.574 .563,50$} & TOTAL & $\mathrm{R} \$ 839.767,20$ \\
\hline & MONETIZAÇÃO & \\
\hline \multirow{3}{*}{ - R\$ 12.366,62 } & Produção & \\
\hline & Sequestro / Emissão de $\mathrm{CO}_{2}$ eq. & $+\mathrm{R} \$ 110.373,75$ \\
\hline & Água de processo & \\
\hline \multirow[t]{2}{*}{$+\mathrm{R} \$ 132,68$} & Gastos com água & $+\mathrm{R} \$ 14.926,86$ \\
\hline & Destinação final & \\
\hline$-\mathrm{R} \$ 53.590,68$ & Valor do composto & Zero \\
\hline Zero, pela compostagem & Espaço em aterro sanitário & + R\$10.722,77 \\
\hline $\mathbf{R} \$ 1.508 .738,88$ & TOTAL & $\mathbf{R} \$ 975.790,58$ \\
\hline
\end{tabular}

Quadro 3 - Comparativo, com biodigestão dos copos de mandioca

\begin{tabular}{|c|c|c|}
\hline MANDIOCA & & PLÁSTICO \\
\hline $\mathrm{R} \$ 300,00$ & Preço de venda do milheiro & $\mathrm{R} \$ 80,00$ \\
\hline 5.248 .545 & Volume anual de copos & 10.497 .090 \\
\hline \multirow[t]{2}{*}{$1.574 .563,50$} & TOTAL & $839.767,20$ \\
\hline & MONETIZAÇÃO & \\
\hline \multirow{3}{*}{$-\mathrm{R} \$ 12.366,62$} & Produção & \\
\hline & Sequestro de $\mathrm{CO}_{2}$ eq. & \\
\hline & Emissões de $\mathrm{CO}_{2}$ eq. & + R\$ $110.373,75$ \\
\hline \multicolumn{3}{|c|}{ Água de processo } \\
\hline$+\mathrm{R} \$ 132,68$ & Gastos com água & + R\$ 14.926,86 \\
\hline \multicolumn{3}{|c|}{ Destinação final } \\
\hline - R\$ $199.268,88$ & Valor do biogás & Zero \\
\hline Zero, pela biodigestão & Espaço em aterro sanitário & $+\mathrm{R} \$ 10.722,77$ \\
\hline$R \$ 1.363 .060,68$ & TOTAL & $\mathbf{R} \$ 975.790,58$ \\
\hline
\end{tabular}

\subsection{9.}

\section{Análise dos resultados}

O estudo tomou como base a produção do ano de 2013 da empresa CBPAK, que foi de 5.428.545 copos de mandioca, oriundos da transformação de 60 toneladas de fécula.

Como indicadores de impacto ambiental, foram utilizados a neutralização do carbono, o consumo de água de processo, o volume dos resíduos sólidos gerados e as destinações finais. Cada impacto ambiental foi avaliado seguindo métrica de uso no mercado (inventário de carbono) e devidamente monetizado. As emissões 
de Gases de Efeito Estufa (GEE) e o consumo de água entre os dois tipos de copos foram inventariadas e comparadas.

Para metrificar os ciclos de vida dos produtos em pauta, foram realizados inventários de carbono da obtenção da matéria-prima, do transporte e do processamento. Nessa etapa, foram utilizadas as emissões de GEE e os volumes de água de processo e de descarte dos dois tipos de embalagens.

Para monetizar esses indicadores, foram tomadas como base ações utilizadas pelo mercado para neutralizar ou compensar o carbono, como o plantio de árvores, empregado no presente estudo. No modelo de monetização do ciclo de vida das embalagens compostáveis, foram utilizados quatro indicadores: carbono, água, espaço em aterro sanitário, composto orgânico e biogás. O custo ambiental foi incorporado ao custo total das embalagens compostáveis.

É prática comum a destinação final dos copos plásticos ser os lixões, o que é sobejamente documentado em estudos acadêmicos e técnicos e em textos jornalísticos. São enormes os impactos ambientais, e são vários os fatores que levam a isso. Essas rotas estão identificadas no estudo, incluindo a geração, o tratamento e a destinação final dos resíduos sólidos. Também são descritas as rotas da destinação final dos copos de mandioca, com destaque para a compostagem e os biodigestores.

Os resultados da comparação sob os pontos de vista ambiental e financeiro foram os seguintes:

- Indicadores ambientais - (quadro 1, pg. 78).

- $\mathrm{CO}_{2 \text { eq. }}$ - sequestro de 19,6 t de $\mathrm{CO}_{2}$ eq. por parte dos copos de mandioca contra a emissão de $\mathbf{1 7 5 , 2 0}$ t de $\mathbf{C O}_{2}$ eq. nos de plástico;

- Agua de processo - copos de plástico mais de mil vezes maior (em $\mathrm{m}^{3}$ )

- Volume de descarte nos aterros - 47 toneladas de lixo dos copos de plástico contra zero (lixo zero) dos copos de mandioca (compostagem ou biodigestores).

- Indicadores financeiros - (quadros 2 e 3, pgs. 78 e 79).

- Preços originais de venda: $\mathrm{R} \$ 300,00$ dos copos de mandioca contra $\mathrm{R} \$$ 80,00 dos de plástico, por milheiro. (proporção de $\mathbf{3 , 7 5}$ vezes)

- Contabilizadas as externalidades e o custo ambiental no valor monetário final, a relação cai para 1,54 vezes. 


\section{5 \\ Conclusões}

O propósito maior da presente dissertação foi propor um modelo metrológico replicável, passível de ser adaptado e utilizado em outras áreas e para outros produtos, como dito no objetivo geral - desenvolver uma metodologia para metrificar e monetizar o ciclo de vida de um produto industrial e aplicá-la a um caso real, para validação.

Como base, a ideia elementar, mas nem sempre concretizada, de que todas as discussões nessa temática - sustentabilidade, desenvolvimento e crescimento sustentáveis, limites do crescimento, crise ambiental, bem como as práticas da cidadania ecológica e responsabilidade ambiental do cidadão a que se refere o Papa Francisco - precisam estar suportadas por dados e informações quantificadas e validadas. Especular e filosofar abstratamente sobre tais conceitos não cabe na empresa, entidade social que está no centro da utilização e da transformação dos recursos ambientais em bens requeridos pela sociedade, daí a necessidade da metrologia: "não se pode gerenciar o que não se pode medir".

Como dificuldade, entretanto, o reconhecimento de que a diversidade de produtos e ciclos leva à precariedade de dados, em um quadro em que o conceito de ciclo completo de produto ainda não está introjetado no dia a dia das empresas. No caso em pauta, além disso, enquanto são fartos os estudos sobre as embalagens de plástico, é pioneira a metrificação e monetização de embalagens compostáveis de mandioca.

No pano de fundo que baliza os conceitos e métodos desenvolvidos estão as políticas públicas aplicáveis, em especial a Política Nacional de Resíduos Sólidos. Outros conceitos pertinentes foram igualmente levados em conta, como a responsabilidade compartilhada pelo ciclo de vida dos produtos, a Responsabilidade Estendida de Produto, o custo ambiental e, sobretudo, o conceito de Economia Circular no ciclo de vida do produto - da terra à terra.

$\mathrm{Na}$ aplicação da metodologia, para facilidade tanto de desenvolvimento quanto de aplicação e de replicação, separou-se metrificação e monetização. Ficou 
assim definido um conjunto de equações para uma e para outra e para cada produto considerado, a que naturalmente se seguiu a aplicação a um caso real, para validação. O foco sempre foi o rebatimento dos resultados em equações matemáticas que traduzissem o custo ambiental em indicadores representativos.

Em suma, a proposição de uma metodologia para medir e valorar o ciclo de vida de um produto industrial foi alcançada, e o modelo validado na aplicação aos ciclos dos copos descartáveis, de plástico e de mandioca.

Os resultados específicos da comparação entre copos descartáveis das duas origens mostram, primeiro, indicadores ambientais largamente favoráveis ao consumo de copos de mandioca: sequestro de 19,6 t de CO2 eq. por parte dos copos de mandioca contra a emissão de 175,20 t nos de plástico; consumo de água para a produção dos copos de plástico mais de mil vezes maior e volume de descarte nos aterros de 47 toneladas de lixo dos copos de plástico contra zero (lixo zero) dos copos de mandioca (Quadro 1).

Em segundo, do ponto de vista financeiro (Quadros 2 e 3), parte-se de uma enorme diferença de preços: $\mathrm{R} \$ 300,00$ dos copos de mandioca contra $\mathrm{R} \$ 80,00$ dos de plástico, por milheiro, uma proporção de 3,75 vezes. Entretanto, uma vez contabilizadas as externalidades e a responsabilidade estendida sobre o produto, essa relação cai para 1,54 .

Essa redução já seria por si só altamente expressiva. Examinando os quadros mais detalhadamente, contudo, salta aos olhos o baixo valor atribuído à destinação final dos copos de plástico, nos aterros sanitários. É de apenas R $\$ 0,001$ (um décimo de centavo) por copo. No caso, são quase 50 toneladas de plástico, para não falar do volume que essa quantidade ocupa, que nunca irão se degradar! Sob o ponto de vista ambiental, portanto, é altamente discutível o baixo valor que se atribui a esse fator.

Esse quadro de desvalorização dos efeitos ambientais poderá mudar? Sim, com a cidadania ecológica e a responsabilidade ambiental do cidadão, a conscientização para a não geração de resíduos sólidos a que a sociedade está sendo chamada. Prahalad e Hamel (1990) definem "competência essencial" (core competence) como sendo uma combinação harmônica de múltiplos recursos e habilidades que distinguem uma empresa no mercado, em função de uma organização ou produto oferecer determinado benefício aos clientes. Na medida em que o cliente percebe o valor gerado na solução e os seus benefícios, ele estará 
identificando uma competência essencial, o que é um fator fundamental e importante na diferenciação do produto.

A competência essencial revelada pelo modelo de metrificação e monetização proposto, na visão macro e aplicável tanto às embalagens de mandioca como a outros produtos, têm um impacto profundo sobre o potencial de crescimento e diferenciação competitiva de um produto e também de uma empresa. O que se oferece é um conceito de sustentabilidade, acompanhado de um custo ambiental, que reflete uma tendência mundial de alteração de hábitos de consumo e de atitudes como contribuição para um mundo cada vez mais atento às regras básicas de um desenvolvimento sustentável.

Nesses termos, a expectativa de trabalhos como este é que possam dar contribuição para uma sociedade melhor estruturada na prosperidade, na inclusão social, na sustentabilidade e nas boas práticas de governança, na linha da teoria das fronteiras planetárias pregada por Rockstrom (2009). E que, como propõe a acadêmica Vera Feitosa (Redação de textos científicos. Rio de Janeiro, Papirus Editora, 1991, p.63):

Além de desempenhar o papel de fecho de uma demonstração, de foz daquela corrente de ideias, a conclusão pode - e deve - servir para abrir novos horizontes, para apontar caminhos, para despertar novas questões ou dúvidas, enfim, para inserir o trabalho no fluxo da busca científica que o transcendem 
6

Referências Bibliográficas

AMAZONAS, M. O pluralismo da economia ecológica e a economia política do crescimento e da sustentabilidade. In: ENCONTRO DA SOCIEDADE

BRASILEIRA DE ECONOMIA, 8., 2009, Cuiabá. Brasília: Ecoeco, 2009, pp. 5-12.

AB'SABER, A. N. Do Código Florestal para o Código da Biodiversidade. Biota

Neotropica, ISSN 1676-0603, v10, n4, 2010.

BOFF, L. Ecologia: Grito da terra, grito dos pobres. São Paulo: Ática, 1995.

CREMONEZ, P. A. Digestão anaeróbia de polímero orgânico à base de fécula de mandioca. 2015. 98 (Mestrado). Programa de Pós-Graduação em Energia na Agricultura, Universidade Estadual do Oeste do Paraná, Parana. Disponivel em: www://200.201.88.199/portalpos/media/File/energia_agricultura/dissertacao_Paulo_A _Cremonez.pdf

DALY, H. Beyond Growth: The Economics of Sustainable Development. Boston: Beacon Press, p 253, 1996.

EAGAN, P.D.; JOERES, E. The utility of environmental impact information: a manufacturing case study. In: Journal of Cleaner Production, v. 10, p. 75-83, 2002.

GIANELLI, B. Avaliação do Ciclo de Vida e o Impacto Ambiental de Produtos e Serviços. Apresentação não publicada. São Paulo, UNESP, 2014.

HANSEN D. R., MOWEN M. M. Gestão de Custos - Contabilidade e Controle. São Paulo: Pioneira Thomson Learning, 2001.

HAQ, Mahbub ul Haq.The Poverty Curtain: Choices for the Third World. New York: Columbia University Press, 1976.

INSTITUTO DE PESQUISA ECONÔMICA APLICADA. Diagnóstico dos resíduos sólidos urbanos. Relatório de pesquisa. IPEA, 2010. Disponível em:

http://www.ipea.gov.br/agencia/images/stories/PDFs/relatoriopesquisa/121009_relato rio_residuos_solidos_urbanos.pdf. Acesso em 08 set. 2015.

INSTITUTO NACIONAL DE METROLOGIA QUALIDADE E TECNOLOGIA. Vocabulário Internacional de Metrologia: conceitos fundamentais e gerais e termos associados (VIM 2012). Duque de Caxias, Rio de Janeiro: INMETRO 2012.

JASCH, C. The use of Environmental Management Accounting (EMA) for identifying environmental costs. Journal of Cleaner Production, v. 11, p. 667-676, 2003.

J.M. KOOIJMAN, Environmental assessment of food packaging: impact and 
improvement. Packag. Technol. Sci., 7, 111-21 Packaging Technology and Science 1994; 7(3). DOI: $10.1002 /$ pts.2770070302

KOTLER, P. Marketing 3.0. 240p, ISBN 9788535238693, I Ed., Editora Elsevier, 2010

LEITE, Paulo Roberto. Logística Reversa - Nova área da logística empresarial. São Paulo: Publicare, 2002.

LOVINS, A., Hawken, P., Lovins, L. H. Capitalismo Natural. São Paulo: Cultrix, p.358, 2010.

MALTHUS, T. R. An Essay on the Principle of Population, as it affects the future improvement of society, London: J. Johnson, in St. Paul's Church-yard, 1Ed.,1798.

MARTINEZ ALIER, J. Da economia ecológica ao ecologismo popular. 366p, Editorial: ICARIA, ISBN: 9788474262278, Barcelona, 1992

MASSUKADO, L.M. Desenvolvimento do processo de compostagem em unidade descentralizada e proposta de software livre para o gerenciamento municipal dos resíduos sólidos domiciliares. 182p. Tese (Doutorado) - Escola de Engenharia de São Carlos, Universidade de São Paulo, São Carlos, 2008.

MEADOWS, D.H., MEADOWS, D.L., RANDERS, J. and BEHRENS III, W.W. The Limits to Growth: a Report for the Club of Rome's Project on the Predicament of Mankind. New York: Universe Books, 1972.

REGATSCHNIG, H.D.; SCHNITZER, H. A techno-economic approach to link waste minimization technologies with the reduction of corporate environmental costs: effects on the resource and energy efficiency of production. Journal of Cleaner Production, v. 6, p. 213-225, 1998.

ROCKSTROM, J. Stockholm Resilience Centre - Stockholm Environment Institute Sustainability: prepare for impact. Palestra proferida na Utrecht University em 3 de Dezembro de 2009. In: NATURE, v. 461/24, set. 2009.

SACHS, I. Estratégias de Transição para do século XXI - Desenvolvimento e Meio Ambiente. São Paulo: Studio Nobel, 1993.

SACHS, J. The age of the sustainable development. 544p, Publisher: Columbia University Press, ISBN-10: 0231173156, ISBN-13: 978-0231173155, March 3, 2015

SOLOW,R. M.. Intergenerational Equity and Exhaustable Resources: Working papers 103, Massachusetts Institute of Technology (MIT), Department of Economics, 1973.

TURNER, G. M. A comparison of The Limits to Growth with 30 years of reality. Global Environmental Changes, 18,00. 397-411, 2008. 


\title{
Anexo I: Exposição de motivos da PNRS
}

\author{
EM № 58/MMA/2007 \\ Brasília, 4 de julho de 2007. \\ Excelentíssimo Senhor Presidente da República,
}

1. Submeto à apreciação de Vossa Excelência o projeto de lei que dispõe sobre as diretrizes aplicáveis aos resíduos sólidos, institui a Política Nacional de Resíduos Sólidos, e dá outras providências.

2. A geração de resíduos sólidos é um fenômeno inevitável que ocorre diariamente, ocasionando danos muitas vezes irreversíveis ao meio ambiente. A preocupação para com os resíduos é universal e vem sendo discutida há algumas décadas nas esferas nacional e internacional. Acrescido a isso, a expansão da consciência coletiva com relação ao meio ambiente e a complexidade das atuais demandas ambientais, sociais e econômicas, induzem a um novo posicionamento dos três níveis de governo, da sociedade civil e da iniciativa privada em face de tais questões. A crescente ideia de preservação dos recursos naturais e a questão de saúde pública associada aos resíduos sólidos indicam que a gestão integrada de resíduos sólidos e os processos de tecnologia limpa são caminhos ambientalmente saudáveis, economicamente viáveis e tendem a ser cada vez mais demandados pela sociedade.

3. A primeira Conferência Mundial sobre Ambiente Humano, Estocolmo (1972) estabeleceu as diretrizes e princípios para a preservação e conservação da natureza e as bases consensuais do desenvolvimento sustentável, que buscam harmonizar o desenvolvimento econômico com a proteção ambiental. Já a reunião da Comissão Mundial sobre o Meio Ambiente e Desenvolvimento, realizada em 1982, que resultou no Relatório Bründtland, consolidou uma visão crítica do modelo de desenvolvimento adotado pelos países industrializados e mimetizado pelas nações em desenvolvimento, ressaltando a incompatibilidade entre os padrões de produção e consumo vigentes, o uso racional dos recursos naturais e a capacidade de suporte dos ecossistemas.

4. A Conferência das Nações Unidas do Meio Ambiente e Desenvolvimento Rio 92 - consolidou o conceito de desenvolvimento sustentável como uma diretriz 
para a mudança de rumos do desenvolvimento global. Este conceito está fundamentado na utilização racional dos recursos naturais de maneira que possam estar disponíveis para as futuras gerações, garantindo a construção de uma sociedade mais justa, do ponto de vista ambiental, social, econômico e de saúde. Os compromissos assumidos pelos Governos naquela ocasião pressupõem a tomada de consciência sobre o papel ambiental, econômico, social e político que cada cidadão desempenha em sua comunidade, exigindo a integração de toda a sociedade no processo de construção do futuro e ainda recomenda que o manejo ambientalmente saudável de resíduos deva ir além do simples depósito ou aproveitamento dos resíduos por métodos seguros, mas deve-se buscar a resolução da causa fundamental do problema, procurando mudar os padrões não sustentáveis de produção e consumo, reforçando a adoção e a internalização do conceito dos 3Rs - Reduzir, Reutilizar e Reciclar - em todas as etapas do desenvolvimento.

5. No Brasil, as primeiras iniciativas legislativas para a definição de diretrizes voltadas aos resíduos sólidos surgiram no final da década de 80. Desde então, foram elaborados mais de 100 projetos de lei, os quais, por força de dispositivos do Regimento Interno da Câmara dos Deputados, encontram-se apensados ao Projeto de Lei $\mathrm{n}^{\mathrm{o}}$ 203, de 1991 que dispõe sobre acondicionamento, coleta, tratamento, transporte e destinação dos resíduos de serviços de saúde, estando pendentes de apreciação.

6. Em 1998, foi constituído um Grupo de Trabalho no âmbito do Conselho Nacional de Meio Ambiente-CONAMA, do qual fizeram parte representantes das três esferas de governo e da sociedade civil, cujo produto dos trabalhos foi a Proposição CONAMA n- 259, de 30 de junho de 1999, intitulada "Diretrizes Técnicas para a Gestão de Resíduos Sólidos". Esta proposição foi aprovada pelo Plenário do CONAMA, mas não chegou a ser publicada, não entrando em vigor.

7. Em 2001, a Câmara dos Deputados criou e implementou a "Comissão Especial da Política Nacional de Resíduos" com o objetivo de apreciar as matérias contempladas nos projetos de lei apensados ao Projeto de Lei n$^{0} 203$, de 1991, e formular uma proposta substitutiva global. Com o encerramento da legislatura, a Comissão foi extinta, sem que houvesse algum encaminhamento. Em 2005 foi instituída uma nova Comissão Especial com o propósito de discutir o assunto.

8. A I Conferência Nacional de Meio Ambiente realizada em 2003 marcou o início de uma nova etapa na construção política de meio ambiente do Brasil, por ser a primeira vez que diversas representações da sociedade se reuniram para compartilhar 
propostas à política pública de meio ambiente. A II Conferência Nacional de Meio Ambiente, realizada em 2005, buscou consolidar a participação da sociedade brasileira no processo de formulação das políticas ambientais e trouxe como um dos temas prioritários a questão dos resíduos sólidos. Assim, mesmo que as deliberações da I Conferência estejam sendo contempladas no âmbito do Governo Federal, a discussão sobre os resíduos sólidos efetuada durante a II Conferência, foi uma demonstração inequívoca da necessidade do estabelecimento de diretrizes nacionais que amparam a questão.

9. Ainda em 2003, o Grupo de Trabalho Interministerial de Saneamento Ambiental, instituído por Vossa Excelência para realizar estudos e elaborar propostas para promover a integração das ações de saneamento ambiental no âmbito do Governo Federal reestruturou o Setor de Saneamento do Governo Federal que resultou, entre outros avanços, na criação do Programa Resíduos Sólidos Urbanos. O programa vem possibilitando a integração entre diversos órgãos federais que desenvolvem ações na área de resíduos sólidos com vistas a uma atuação coerente e mais eficaz. O programa integra quatro ministérios e tem como objetivo a organização dos catadores, visando sua emancipação econômica, a ampliação dos serviços com inclusão social e sustentabilidade dos empreendimentos de limpeza urbana, a redução, reutilização e reciclagem dos resíduos e a erradicação dos lixões. Fazem parte do Programa: o Ministério das Cidades, da Saúde, por meio da Fundação Nacional de Saúde, do Trabalho e Emprego, do Desenvolvimento Social e Combate à Fome e do Desenvolvimento, Indústria e Comércio Exterior, por meio do Banco Nacional de Desenvolvimento Social e o Ministério do Meio Ambiente que o coordena.

10. Como na gestão dos resíduos sólidos, a sustentabilidade se constrói a partir de modelos integrados, que possibilitem tanto a redução como a reutilização e a reciclagem de materiais que possam servir de matéria-prima para processos produtivos, diminuindo o desperdício e gerando renda, é conveniente mencionar que para a garantia da sustentabilidade na gestão integrada de resíduos sólidos não pode ficar cingida à apenas uma área técnica, pois a busca para a solução dos problemas tem como fator determinante a integração outras áreas a saúde, a fazendária, a de planejamento e as sociais, Desta forma, a integração das demais áreas técnicas trarão significativos avanços para a questão.

11. Durante o ano de 2004, o Ministério do Meio Ambiente envidou esforços no sentido de elaborar uma proposta de texto para a regulamentação da questão dos 
resíduos sólidos no país, promovendo grupos de discussões interministeriais e de representantes de diversas secretarias do Ministério do Meio Ambiente. O CONAMA realizou em agosto do mesmo ano, o Seminário intitulado "Contribuições à Política Nacional de Resíduos Sólidos" que teve como principal objetivo a busca de subsídios da sociedade em geral para a formulação de uma nova proposta de projeto de lei, pois o conteúdo da Proposição CONAMA n ${ }^{\circ} 259$ encontrava-se defasado.

12. No início de 2005, foi criado um grupo interno na Secretaria de Qualidade Ambiental nos Assentamentos Humanos do Ministério do Meio Ambiente para consolidar e sistematizar as contribuições do Seminário CONAMA, os anteprojetos de lei existentes no Congresso Nacional e as contribuições dos diversos atores envolvidos na gestão de resíduos sólidos. Como resultado dessa consolidação foi elaborada a proposta que ora está sendo encaminhada como um anteprojeto de lei de "Política Nacional de Resíduos Sólidos". Esse anteprojeto foi debatido com os Ministérios das Cidades, da Saúde, mediante sua Fundação Nacional de SaúdeFUNASA, do Desenvolvimento, Indústria e Comércio Exterior, do Planejamento, Orçamento e Gestão, do Desenvolvimento Social e Combate à Fome e da Fazenda, buscando nas discussões a sustentabilidade requerida para a temática.

13. Discussões com a sociedade, sobre o conteúdo do anteprojeto de lei da Política Nacional de Resíduos Sólidos foram promovidas por meio dos seminários regionais de resíduos sólidos - instrumentos para gestão integrada e sustentável -, promovidos pelos Ministérios do Meio Ambiente, das Cidades, FUNASA e Caixa Econômica Federal e de igual forma com a sociedade civil no CONAMA, com a Confederação Nacional das Indústrias-CNI, com a Federação das Indústrias do Estado de São Paulo-FIESP, com a Associação Brasileira de Engenharia Sanitária-ABES, com o Compromisso Empresarial para Reciclagem-CEMPRE, e com outras entidades e organizações afins, tais como: Fórum Lixo \& Cidadania, Comitê Interministerial de Inclusão Social dos Catadores de Lixo.

14. O projeto de lei da Política Nacional de Resíduos Sólidos, considerou o estilo de vida da sociedade contemporânea, que aliado às estratégias de marketing do setor produtivo, levam a um consumo intensivo provocando uma série de impactos ambientais, à saúde pública e sociais incompatíveis com o modelo de desenvolvimento sustentado que se pretende implantar no Brasil. É importante ressaltar que o desenvolvimento de diferentes setores voltados à exportação e ao comércio internacional absorve as novas tendências do crescimento industrial 
utilizando-se de tecnologias mais limpas. Dados obtidos no dia-a-dia evidenciam que a tendência de preservação ambiental e ecológica por parte destes setores deve continuar de forma permanente e definitiva.

15. Neste cenário, os resíduos, principalmente os resíduos perigosos, quando dispostos inadequadamente poluem o solo e comprometem a qualidade das águas superficiais e subterrâneas, com sérias consequências à saúde humana e ao meio ambiente. Indicadores oficiais mostram que no ano 2000, cerca de $60 \%$ dos resíduos coletados foram depositados inadequadamente em lixões, $17 \%$ em aterros controlados e $13 \%$ em aterros sanitários. Observa-se que, em uma década houve um aumento de cerca de $12 \%$ dos resíduos dispostos inadequadamente no solo. Outra grande preocupação é com o desperdício nos diversos setores, com destaque para a construção civil e agricultura, que devido a procedimentos inadequados refletem diretamente no aumento da geração de resíduos.

16. Na ausência de um marco regulatório para os resíduos sólidos, as administrações municipais isoladamente ou com apoio dos governos Estaduais e Federal buscam mecanismos de solução, optando pela instalação de aterros sanitários, que mesmo sendo uma forma adequada ambientalmente de dispor os resíduos, não resolvem a questão. Os estados brasileiros se adiantaram e sete deles já editaram suas Políticas Estaduais de Resíduos Sólidos, 14 estão em fase de discussão, alguns deles com apoio do Ministério do Meio Ambiente, por intermédio do Programa Nacional de Meio Ambiente II. Muitos estados vêm criando benefícios tributários para municípios que manejam adequadamente seus resíduos, demonstrando crescente preocupação frente às demandas da sociedade para com o tema. Com este anteprojeto, o Governo Federal apresenta possibilidades de ajustar a legislação tributária e apresentar propostas para o setor, principalmente para os materiais recicláveis e reciclados. Da mesma forma que estarão sendo estudadas alternativas viáveis de fomento e concessão de crédito para a garantia da sustentabilidade do setor.

17. Todo o apoio das esferas superior se justifica, pois as municipalidades sofrem de deficiência gerencial, técnica, financeira e de participação social diante das tecnologias aplicáveis ao manejo adequado dos resíduos sólidos, visto que, em muitos municípios são manejados conjuntamente os resíduos domésticos, os hospitalares e os industriais, que é uma perigosa convivência, tolerada ou ignorada pelos gestores municipais, que coloca em risco a saúde da população Cabe ressaltar que a firme atuação do Ministério Público tem propiciado melhorias no gerenciamento e na 
disposição adequada dos resíduos nos municípios, sendo que em muitos as dificuldades para resolver a situação são estruturais.

18. Outro aspecto que deve ser considerado é a presença de catadores nas áreas de disposição final. Segundo a PNSB 2000, cerca de 25.000 catadores trabalham nessas áreas, dos quais 22,3\% têm até 14 anos de idade, e ainda não se pode deixar de citar os catadores que vivem nas ruas das grandes cidades brasileiras. Devemos lembrar, inclusive, que Vossa Excelência, vem demonstrando preocupação com a situação degradante de milhares de famílias que se alimentam de restos descartados no lixo e sobrevivem economicamente com a venda dos materiais recicláveis coletados, criando, em setembro de 2003, o Comitê Interministerial de Inclusão Social dos Catadores de Lixo, integrados por diversos ministérios no intuito de propor ações capazes de enfrentar esta situação.

19. Vale ressaltar que em junho de 2001 foi realizado em Brasília o $1^{\underline{0}}$ Congresso Nacional dos Catadores de Materiais Recicláveis, que contou com a participação de 1.600 congressistas, entre catadores, técnicos e agentes sociais de dezessete Estados brasileiros e, como resultado, promoveram a $1^{\underline{a}}$ Marcha Nacional da População de Rua, com 3.000 participantes e apresentaram à sociedade e às autoridades a necessidade da efetivação de políticas públicas voltadas aos catadores. Como decorrência, em janeiro de 2003, foi realizado em Caxias do Sul, o I Congresso Latino-americano de Catadores, que buscou fortalecer o processo de organização destes trabalhadores em associações ou cooperativas, foi elaborado um documento que propõe a capacitação e formação profissional, a erradicação dos lixões, a responsabilização dos geradores de resíduos, entre outros temas.

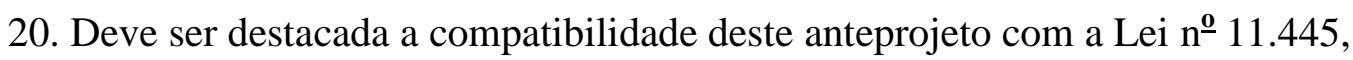
de 5 de janeiro de 2007, que estabelece as diretrizes nacionais para o saneamento básico e para a política federal de saneamento básico, o que reforça a premência de regulamentação do setor. Com essa lei o setor de saneamento avançará e, mais ainda o de resíduos, com a possibilidade de se viabilizar novos arranjos integrados para a adequada gestão dos resíduos sólidos, valendo-se, também, do disposto nas Leis de Consórcios Públicos (Lei n⿳o 11.107, de 2005) e das Parcerias Público-Privadas (Lei n⿳0 11.079, de 2004). Para muitos municípios a possibilidade da constituição de consórcios públicos é uma das formas de enfrentar os problemas referentes à prestação de serviços de limpeza urbana, incluindo a destinação final, com menores custos. 
21. Assim, o encaminhamento do anteprojeto de lei reflete a demanda da sociedade que pressiona por mudanças motivadas pelos elevados custos sócioeconômicos e ambientais. Devemos considerar que na busca da solução para estes problemas, foi fundamental considerar a adoção do conceito dos 3Rs - Reduzir, Reutilizar e Reciclar. Pois, se manejados adequadamente, os resíduos sólidos adquirem valor comercial e podem ser utilizados em forma de novas matérias-primas ou novos insumos. Assim sendo, poderão ser incorporados novamente nas cadeias produtivas, de forma sucessiva e sistêmica.

22. A implantação da lei proposta trará reflexos positivos no âmbito social, ambiental e econômico, pois não só tende a diminuir o consumo dos recursos naturais, como proporciona a abertura de novos mercados, gera trabalho, emprego e renda, conduz à inclusão social e diminui os impactos ambientais provocados pela disposição inadequada dos resíduos. Sendo assim, estaremos inserindo o desenvolvimento sustentável no manejo de resíduos sólidos do país.

23. Portanto, tais fundamentos justificam a implementação de uma Política Nacional de Resíduos Sólidos, que tem por objetivo traçar ações estratégicas que viabilizem processos capazes de agregar valor aos resíduos aumentando a capacidade competitiva do setor produtivo, propiciando a inclusão e o controle social, norteando Estados e Municípios para a adequada gestão de resíduos sólidos.

24. Estas, Senhor Presidente, as significativas razões que propiciam o encaminhamento do anteprojeto de lei, que ora submeto à elevada consideração de Vossa Excelência, e o seu encaminhamento à Câmara dos Deputados.

Respeitosamente,

\section{Marina Silva}

Ministra de Estado do Meio Ambiente 


\section{Anexo II: Glossário}

Ciclo de vida do produto - série de etapas que envolvem o desenvolvimento do produto, a obtenção de matérias-primas e insumos, o processo produtivo, o consumo e a disposição final.

Coleta seletiva - coleta de resíduos sólidos previamente segregados conforme sua constituição ou composição.

Compostagem - processo de biodegradação que consiste na manipulação de material orgânico de acordo com técnicas para acelerar a decomposição e produzir um elemento útil, o composto.

Custo ambiental - é o custo que pode resultar das atividades, estabelecidas em lei ou voluntárias, que visam a evitar, reduzir, tratar ou dispor dos resíduos, rejeitos e emissões da empresa.

Degradação da qualidade ambiental - alteração adversa das características do meio ambiente.

Destinação final ambientalmente adequada - destinação de resíduos que inclui a reutilização, a reciclagem, a compostagem, a recuperação e o aproveitamento energético ou outras destinações admitidas pelos órgãos competentes [...], observando normas operacionais específicas [...];

Disposição final ambientalmente adequada - distribuição ordenada de rejeitos em aterros, observando normas operacionais específicas [...];

Embalagem - recipiente ou envoltura que armazena produtos temporariamente, individualmente ou agrupando unidades, tendo como principal função protegê-lo e estender o seu prazo de vida (shelf life), viabilizando sua distribuição, identificação e consumo (ABRE Associação Brasileira de Embalagens).

Embalagem (uso posterior)

a) Descartável - a ser descartada após a primeira utilização.

b) Retornável - a ser retornada ao processo de fabricação do produto para reenvasamento, passando pelos processos de lavagem e esterilização, bem como pelas etapas de transporte da logística reversa.

c) Reutilizável - a ser reaproveitada pelo consumidor para o acondicionamento de outros produtos e deverá ser ajustada para que seja possível a sua reutilização, sem prejudicar a saúde e a segurança do consumidor.

Embalagem (consistência e matéria-prima)

a) Rígidas - caracterizam-se por sua dureza (vidros, metais, plásticos rígidos).

b) Semirrígidas - possuem menor dureza que as rígidas (garrafas e recipientes plásticos, laminados mistos).

c) Flexíveis - caracterizam-se pela baixa dureza (plásticos, celofane, papel, alumínio).

\section{Embalagem (destinação final)}

- Reciclável - aquela cuja matéria-prima pode ser reaproveitada depois de utilizada, após sofrer uma transformação química ou física, para finalidades diversas.

- Biodegradável (não compostável) - a que pode ser degradada por microorganismos, liberando $\mathrm{CO} 2$ para atmosfera sob determinadas condições de calor, umidade, presença de microorganismos e oxigênio. Este tipo de embalagem 
não é transformado em novo produto ou adubo orgânico.

- Biodegradável compostável - a que pode ser destinada à compostagem orgânica.

- Não biodegradável - a que não se degrada naturalmente ou que o faz após um Embalagem (tipos) prazo superior a 10 anos.

I) Primárias - as que ficam em contato direto com o alimento.

II) Secundárias - as de distribuição, ou seja, protegem as embalagens primárias.

III) Terciárias - as empregadas para acondicionar e proteger as embalagens primárias e secundárias durante o transporte, estocagem e distribuição.

Geradores de resíduos sólidos - pessoas físicas ou jurídicas, de direito público ou privado, que geram resíduos sólidos por meio de suas atividades, nelas incluído o consumo;

Gerenciamento de resíduos sólidos - conjunto de ações exercidas, direta ou indiretamente, nas etapas de coleta, transporte, transbordo, tratamento e destinação final ambientalmente adequada dos resíduos sólidos e disposição final ambientalmente adequada dos rejeitos, [...];

Gestão integrada de resíduos sólidos - conjunto de ações voltadas para a busca de soluções para os resíduos sólidos, de forma a considerar as dimensões política, econômica, ambiental, cultural e social, com controle social e sob a premissa do desenvolvimento sustentável;

Impacto ambiental - alteração no meio ambiente ou em algum de seus componentes por determinada ação ou atividade humana. O objetivo de se estudar os impactos ambientais é, principalmente, o de avaliar as consequências das ações ou atividades para que possa haver a prevenção da alteração da qualidade do ambiente após a execução dessas ações.

Logística reversa - instrumento de desenvolvimento econômico e social caracterizado por um conjunto de ações, procedimentos e meios destinados a viabilizar a coleta e a restituição dos resíduos sólidos ao setor empresarial, para reaproveitamento, em seu ciclo ou em outros ciclos produtivos, ou outra destinação final ambientalmente adequada.

Meio ambiente - o conjunto de condições, leis, influências e interações de ordem física, química e biológica, que permite, abriga e rege a vida em todas as suas formas.

Poluição - degradação da qualidade ambiental resultante de atividades que direta ou indiretamente:

a) prejudiquem a saúde, a segurança e o bem-estar da população;

b) criem condições adversas às atividades sociais e econômicas;

c) afetem desfavoravelmente a biota;

d) afetem as condições estéticas ou sanitárias do meio ambiente;

e) lancem matérias ou energia em desacordo com os padrões ambientais estabelecidos.

Poluidor - pessoa física ou jurídica, de direito público ou privado, responsável, direta ou indiretamente, por atividade causadora de degradação ambiental.

Reciclagem - processo de transformação dos resíduos sólidos que envolve a alteração de suas propriedades físicas, físico-químicas ou biológicas, com vistas à transformação em insumos ou novos produtos, [...];

Recursos ambientais - a atmosfera, as águas interiores, superficiais e subterrâneas, os estuários, o mar territorial, o solo, o subsolo, os elementos da biosfera, a fauna e a flora.

Rejeito - resíduo sólido que, depois de esgotadas todas as possibilidades de tratamento e recuperação por processos tecnológicos disponíveis e economicamente viáveis, não apresente outra possibilidade que não a disposição final ambientalmente adequada.

Resíduo sólido - material, substância, objeto ou bem descartado resultante de atividades humanas em sociedade, a cuja destinação final se procede, se propõe proceder ou se está obrigado a proceder, nos estados sólido ou semissólido, bem como gases contidos em recipientes e líquidos cujas particularidades tornem inviável o seu lançamento na rede pública de esgotos ou em corpos d'água, ou exijam para isso soluções técnica ou 
economicamente inviáveis em face da melhor tecnologia disponível.

Responsabilidade compartilhada pelo ciclo de vida dos produtos - conjunto de atribuições individualizadas e encadeadas dos fabricantes, importadores, distribuidores e comerciantes, dos consumidores e dos titulares dos serviços públicos de limpeza urbana e de manejo dos resíduos sólidos, para minimizar o volume de resíduos sólidos e rejeitos gerados, bem como para reduzir os impactos causados à saúde humana e à qualidade ambiental decorrentes do ciclo de vida dos produtos, [...];

Reutilização - processo de aproveitamento dos resíduos sólidos sem sua transformação biológica, física ou físico-química, [...]. 